Bull. Fac. Agric., Cairo Univ., 71: 215-241 (2020).

\title{
PERCEIVED ORGANIZATIONAL CLIMATE FOR A SAMPLE OF EMPLOYEES IN ENGINEERING OF IRRIGATION IN GHARBIA GOVERNORATE
}

(Received: 25.11.2020)

\author{
By \\ M. F. Ebad-Allah
}

\section{Rural Sociology, Faculty of Agriculture,Tanta University, Gharbia Governorate, Egypt}

\begin{abstract}
The organization of engineering of irrigation is one of the most important organizations at the local level, because it reflects the implementation of policies for managing Egypt's scarce water resources. The importance of studying the organizational climate, is due to the influence of the organizational climate on the organizational behavior of the members of this organization, which affects the success of this organization in achieving its goals. The current article aims to evaluate an organizational climate instrument, and testing the goodness of fit of the proposed causal model. To achieve these goals, an organizational climate instrument was translated and prepared for testing in the Egyptian context. A causal model was also proposed to be tested. To achieve these goals; A sample of 140 employees of the organization of engineering of irrigation was selected in Gharbia Governorate. Multiple linear regression method was used to test the goodness of fit of the proposed causal model. The most important results indicated that the perceived organizational climate instrument used has excellent reliability and validity. Also, there is a high level of positive perception of the organizational climate among the respondents. The results also indicated that the variable of organizational material resources has the largest total causal effect on the perceived organizational climate in the revised model, as well as the variable of perceived organizational climate has the largest total causal effect on the variables of rate of performance of the formal job tasks and organizational ineffectiveness. Despite the high positive level of perceived organizational climate among the respondents, this positive climate does not reflect the rate of performance of the formal job tasks of these employees. The article suggests that necessary procedures should be taken from decision-makers to confront the high negative level of perceived organizational climate of the climate of planning and decision-making, the climate of career development, and the climate of reward system.
\end{abstract}

Key words: Causal Model, Egypt, Engineering of Irrigation and Perceived Organizational Climate.

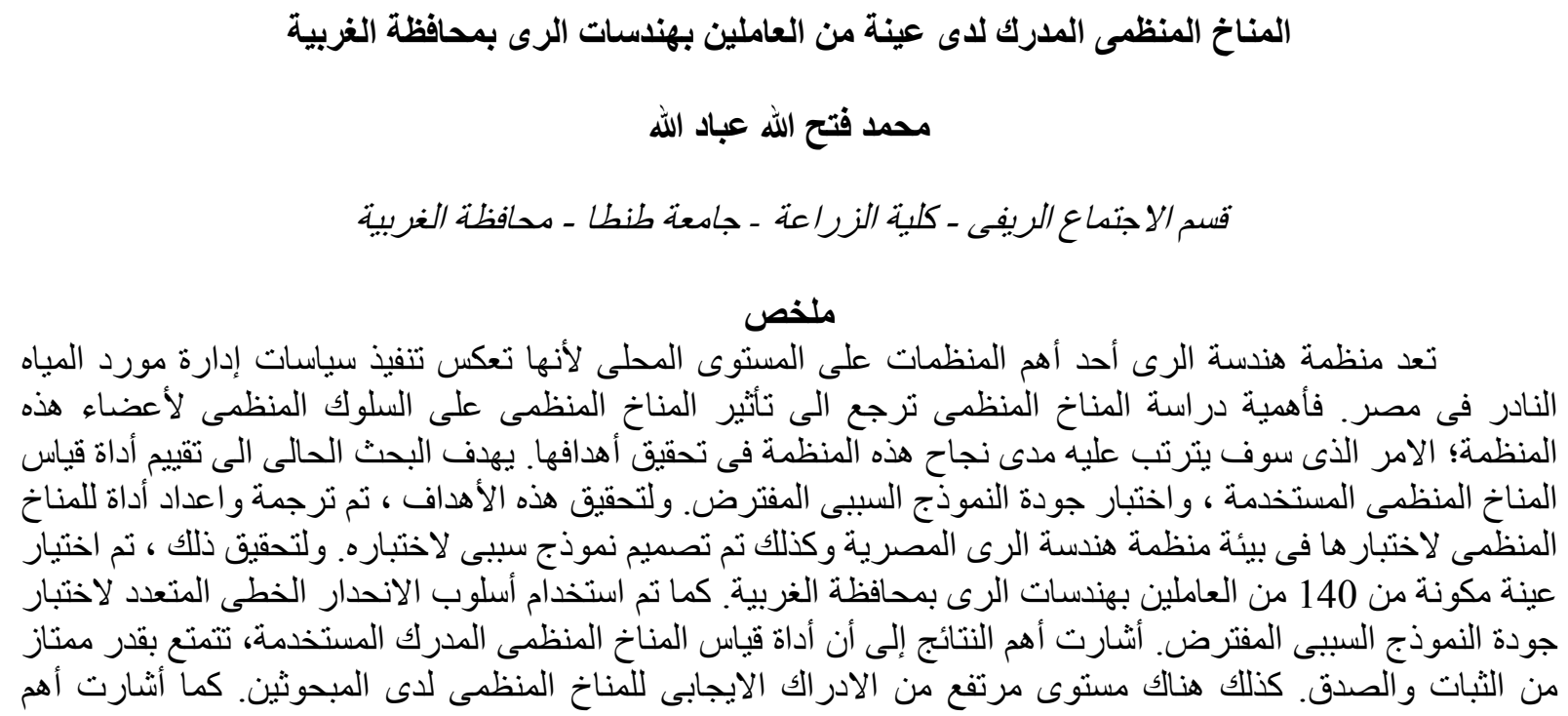




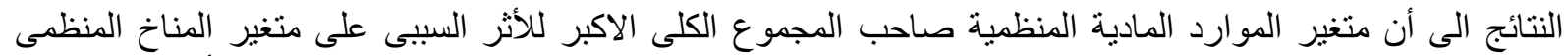

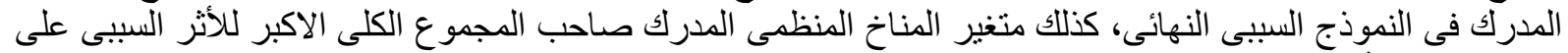

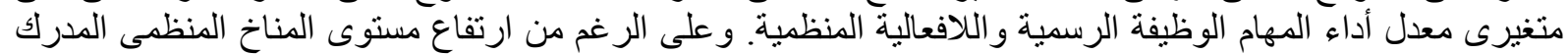

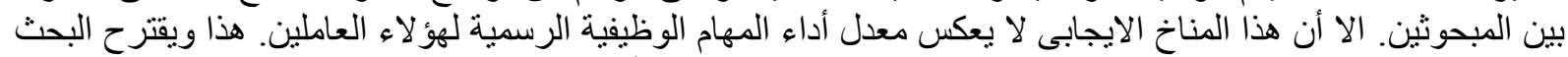

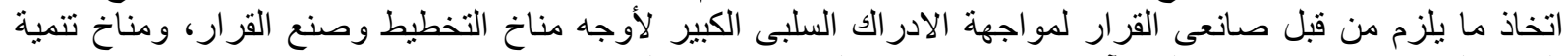

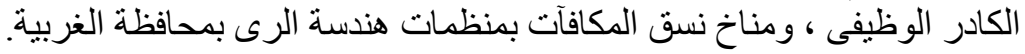

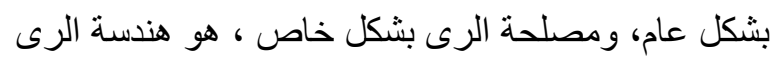

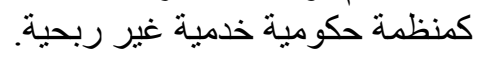

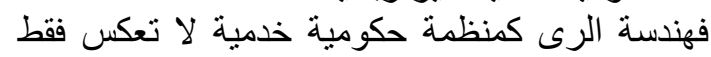

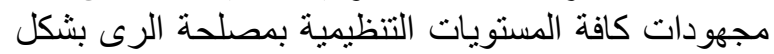

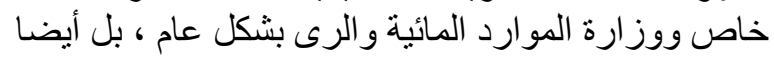

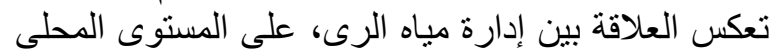

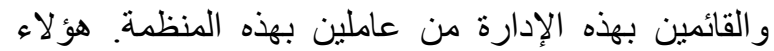

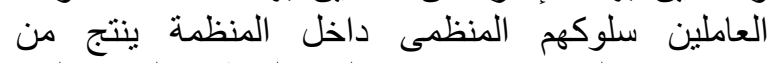

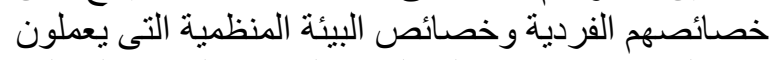

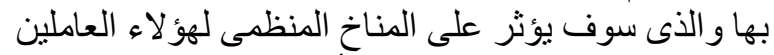

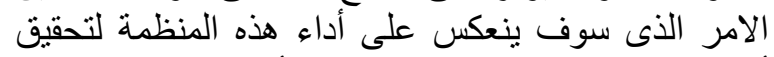

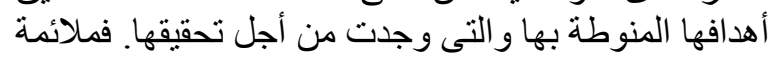

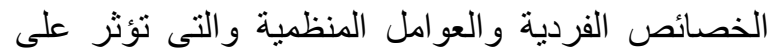

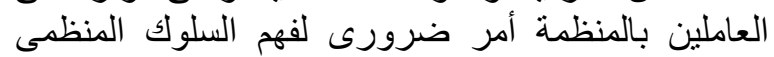

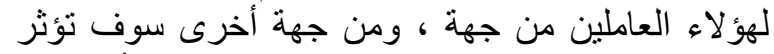
هذه الملائمة على مخرجات لألمن تلك المنظمة من جهة أخرى.

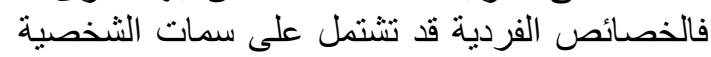

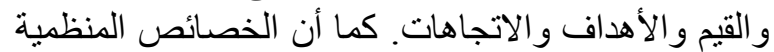

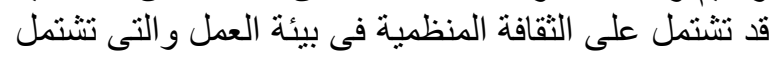

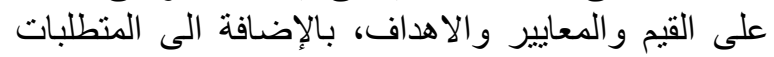

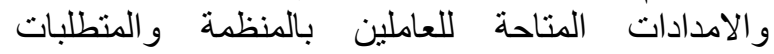

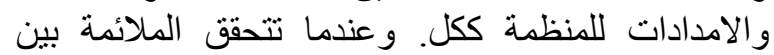

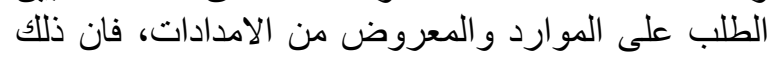

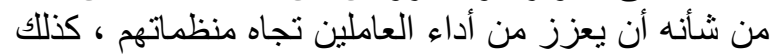

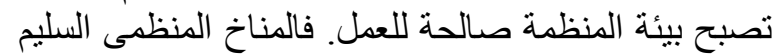

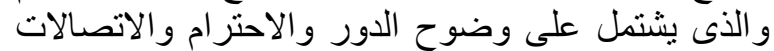

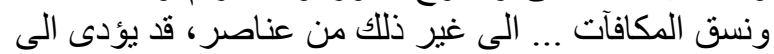

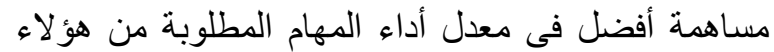

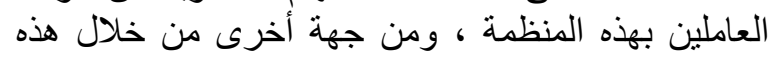

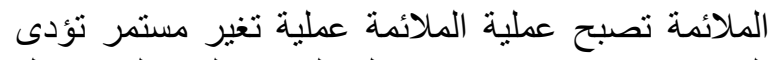

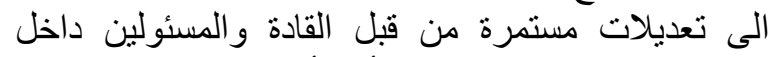

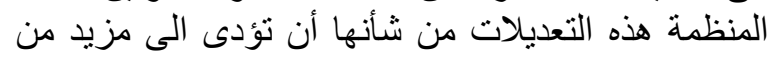

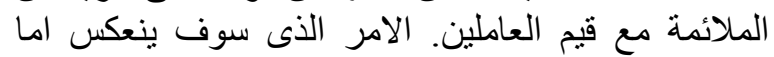

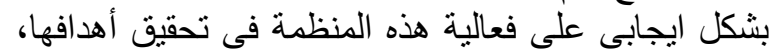

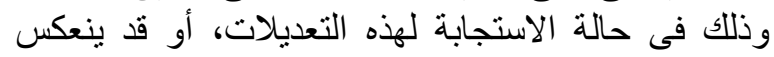

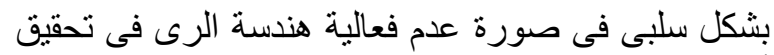
أهدافها؛ وذلك في حالة عدم التدخل لإجر اء تلألك التعديلات

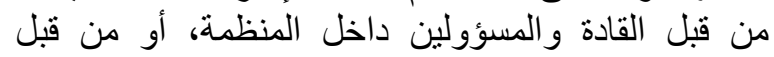

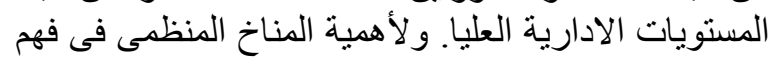

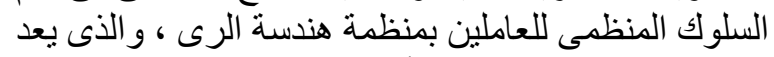

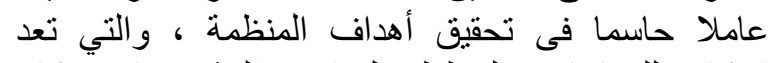

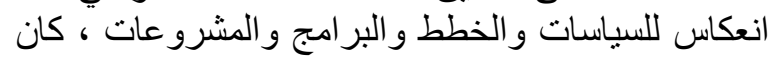
الدافع وراء هذا البحث. فهذا البحث سوف يحاول ولثرول الاجابة

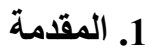

1-1 مشكلة البحث تو اجه مصر تحدى ندرة المياه؛ و هذا التحدى من أكبر

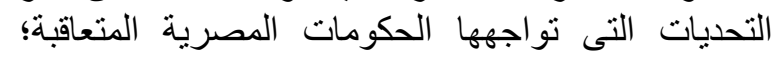

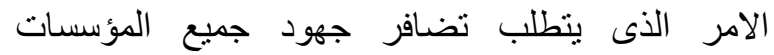

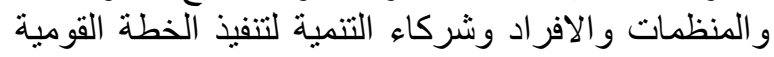

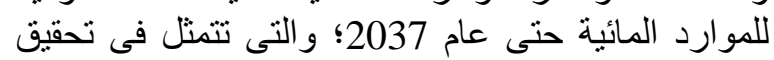

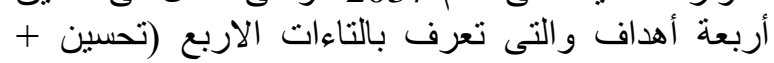

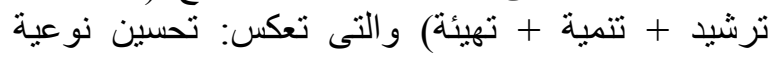

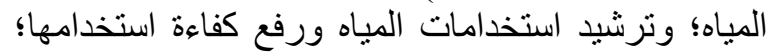
وتنمية الموارد المائية؛ وتهيئة البيأة البئة الملائمة للإدارة

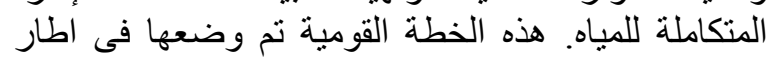

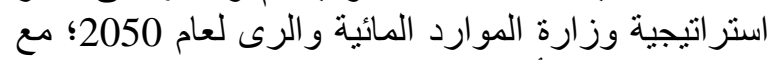

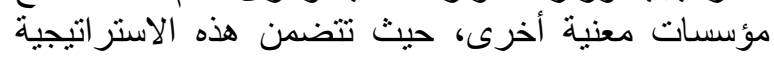

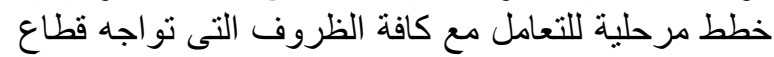

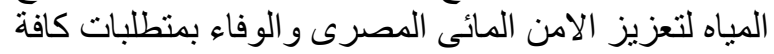

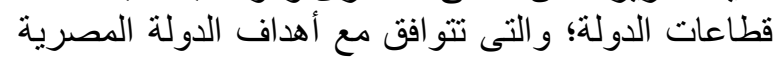

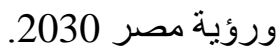
هذا التحدى يتطلب كفاءة وفعالية جميع الأطراف

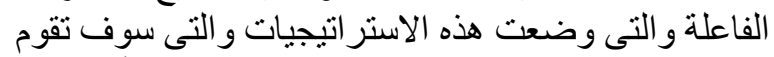

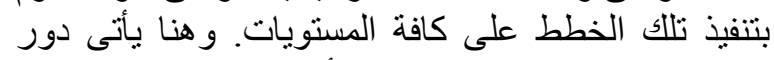

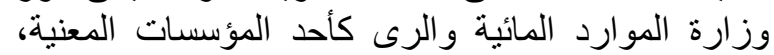

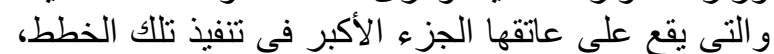

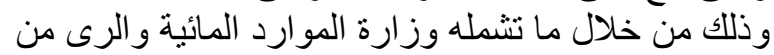

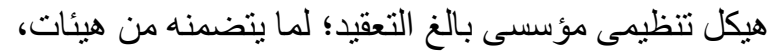

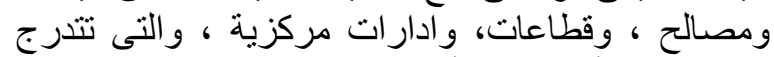

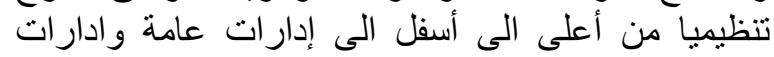

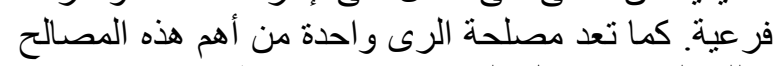

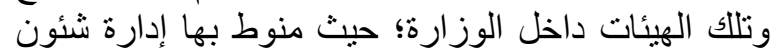

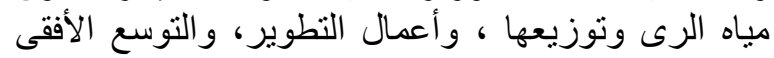

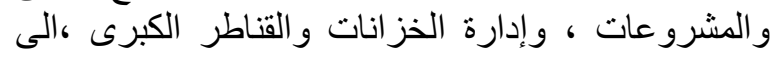

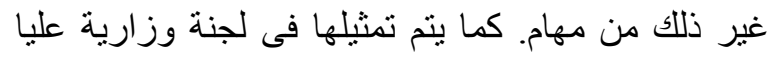
ولجنة وزارية فنية ولجان للموارد المائية بالمحافظات ولئات

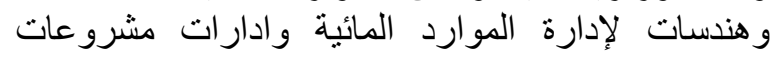

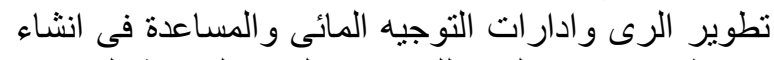

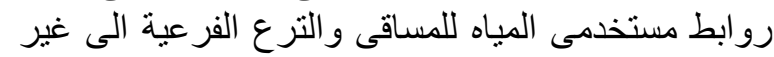
ذللك من اطر اف فاعلة مسئولة عن إدارة مياه الرىى فئى الرى فير

يتضح من هذه المستويات التنظيمية ، و التى تتضمن

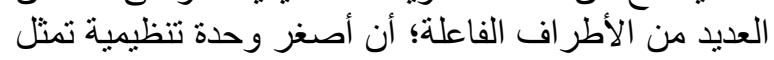

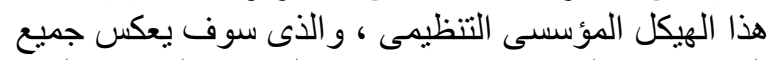
المجهودات التى تقوم بها وزارة المواريكارد المائية والرىى 
والسلوك المنظمى والنتائج الإيجابية المترتبة على ذلك الكي تساهم فى خلق دور حيوى فى النى العمل الذى تقدمه المنظمة النية من حيث الكم و الكيف. (Mullins and Christy, 2010)

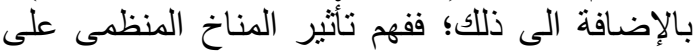

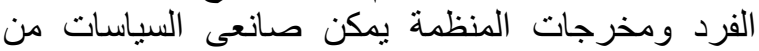
إمكانية تعميم أبعاده المختلفة على أعضاء المناء المنظمات المختلفة؛ كما أنه يوفر فهما لكيفية تأثير أنمانية أنماط الإدارة

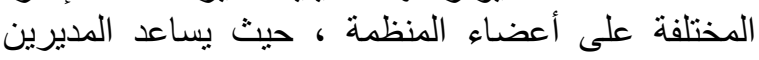

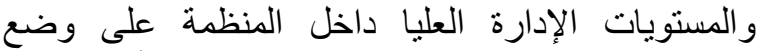

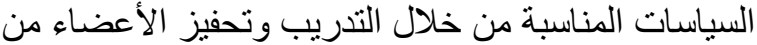

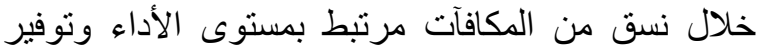

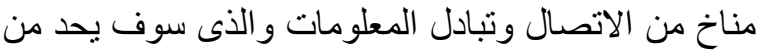

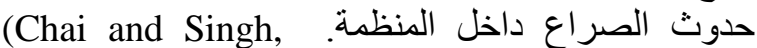
2008; Idogho, 2006)

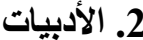

\section{1-2 مفهوم المناخ المنظمى الالي}

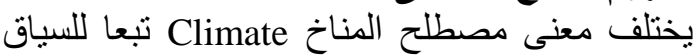
الذى يستخدم فيه ، ففى السياق الجغر الفى يقصد بـ باخ بالمناخ

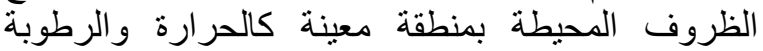
والامطار... الى غير ذلك من ظروف؛ وذلك اللك خلال فترة

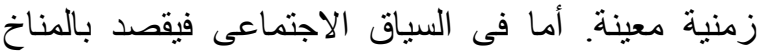

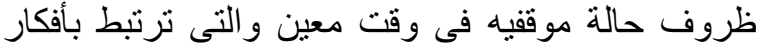

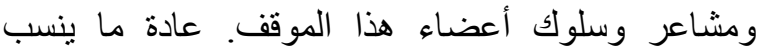

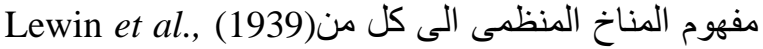

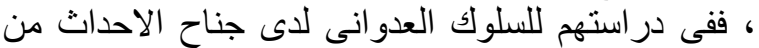

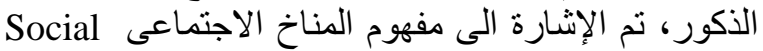

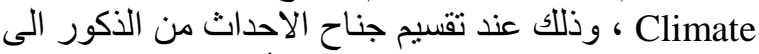

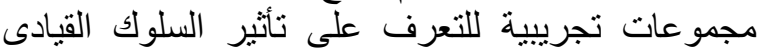

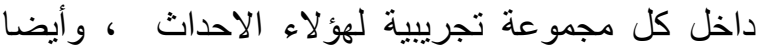

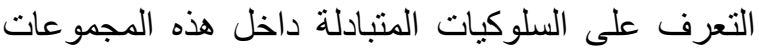

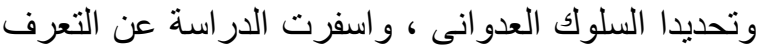

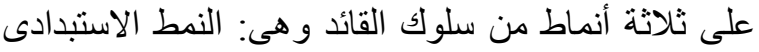

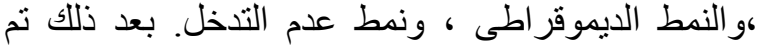

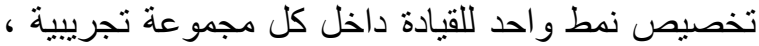

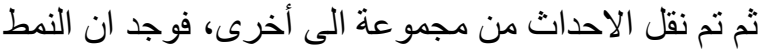

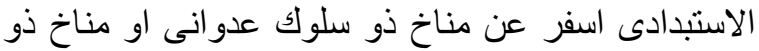

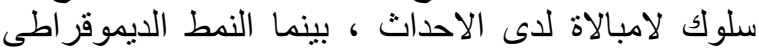

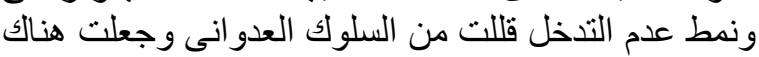

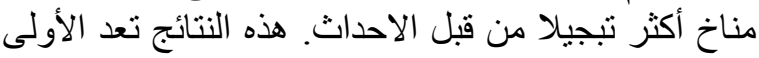
فى در اسة سلوك القيادة و المناخ المنظمى. الاحثى

لاحقا ، نم در اسة ظاهرة المناخ المنظمى بشكل أكثر

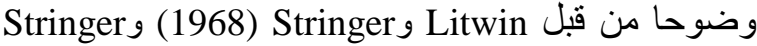
(2002)، حيث قامو بتصميم نمط عمل بالمحاكاة باستخدام ثلاث شركات تصنيع مختلفة. كانت لهذه باته المنظمات باتهات

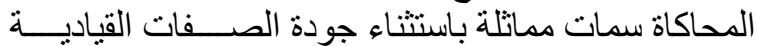

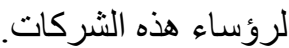

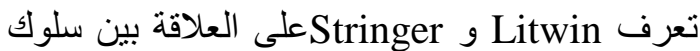
القائد والمناخ المنظمى الذى ير اه العمال، وكذلك العلاقة لئة

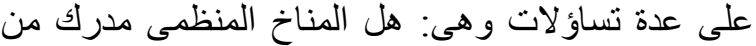

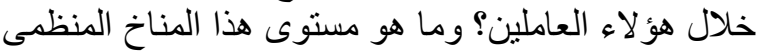

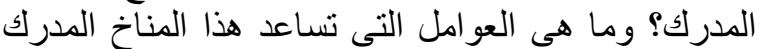

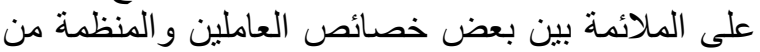

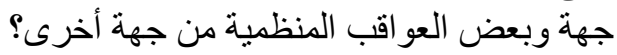

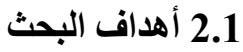

يمكن صياغة الأهداف التالية والتى يسعى هذا البحث

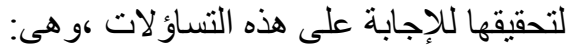

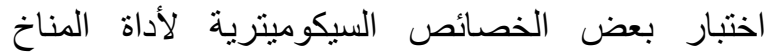

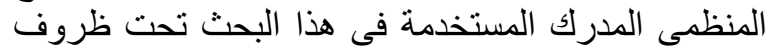
منظمة هندسة الرى المصرية. وصف استجابات المبحوثين على أدرية المداة المناخ المنظمى المدرك المستخدمة في هذا البحث. المئ.

التعرف على مستوى المناخ المنظمى المدرك لدى لدى عينة البحث.

بناء نموذج سببى يوضح العلاقات المنوقعة بين المتغير ات

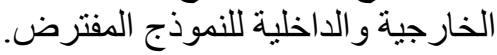
التعرف على مدى مطابقة البيانات الملاحظة للنموذج

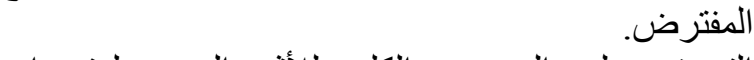
التعرف على المجموع الكلى للأثر السببى لمتغيرات

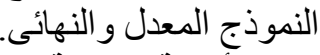
3-1 الأهمية النظرية والتطبيقية للبحث النه

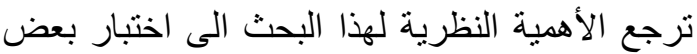

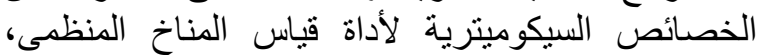

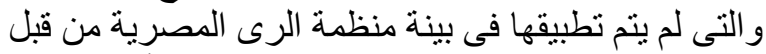

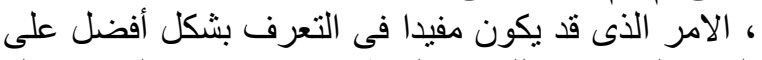

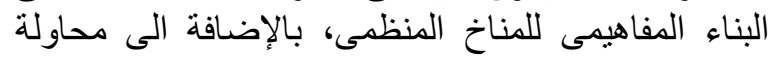

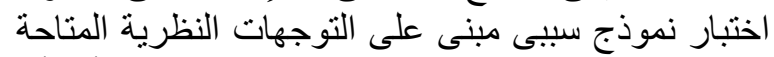

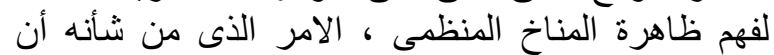

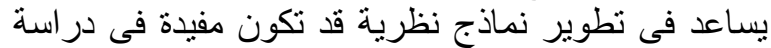
ظاهرة المناخ المنظمى بشكل أفضل.

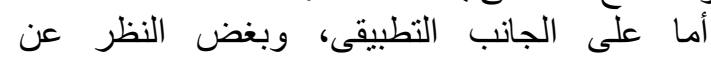
التصور ات النظرية لظاهرة المناخ المنظمى؛ الا ان دراسة

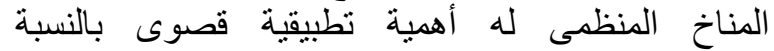

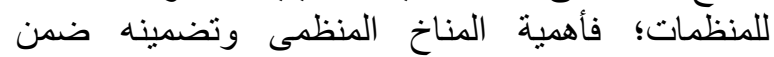

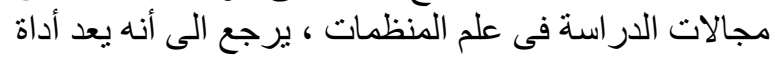

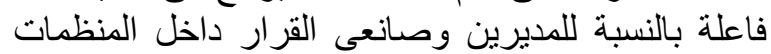

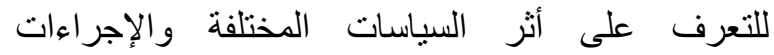
و الممارسات من منظور العاملين بهذه المنظمات.

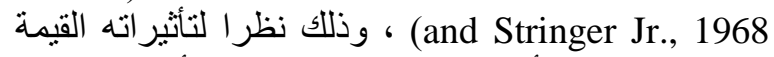

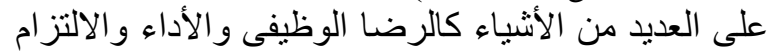

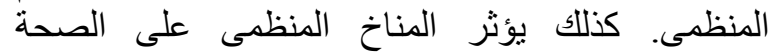

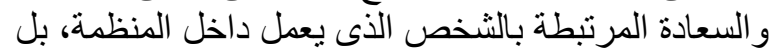

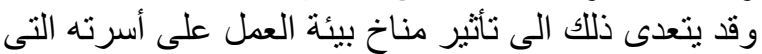

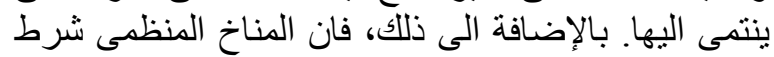

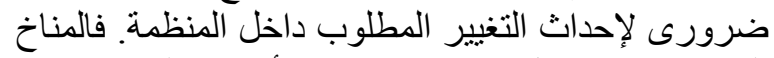

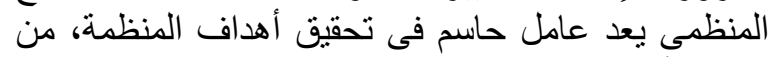

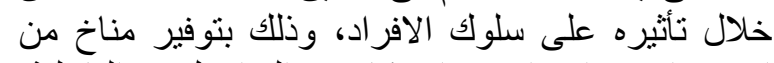

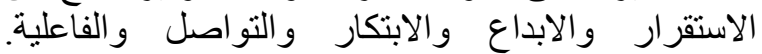

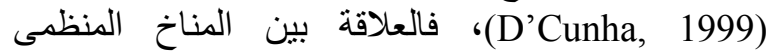


طبيعته ، كذللك يمكن تمييز ظاهرة المناخ من خلال مهمة

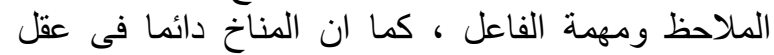

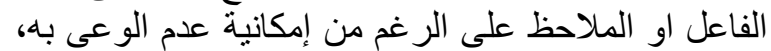

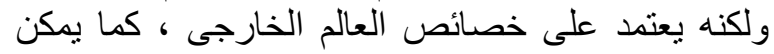

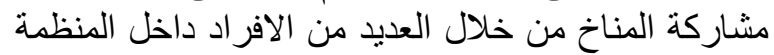

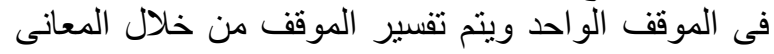

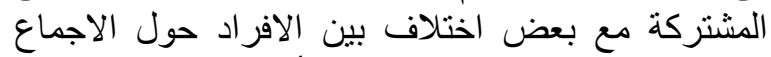

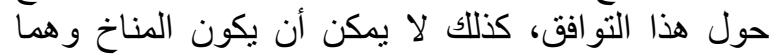

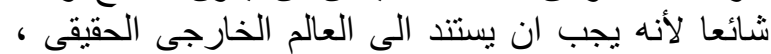

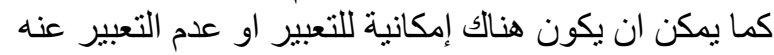

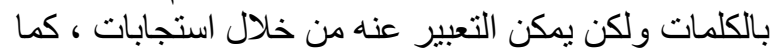

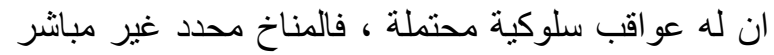

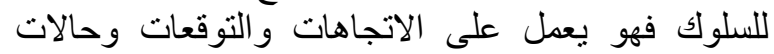
الاثارة والتى تحدد بشكل مباثر السلوك التهات

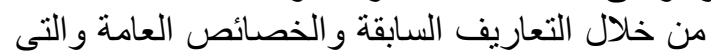

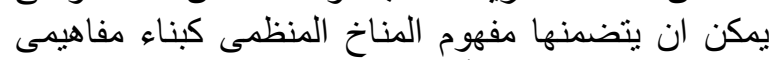

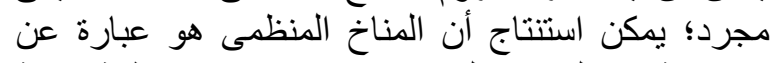

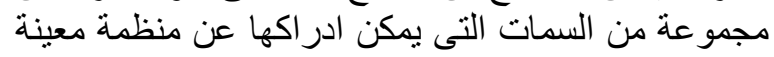

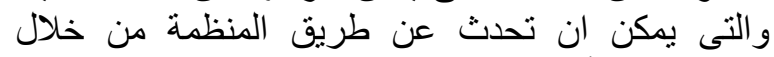

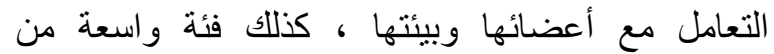

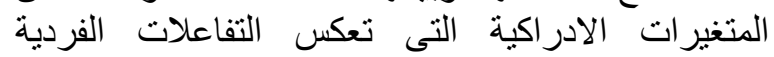

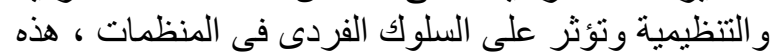

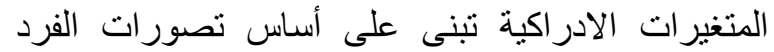

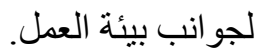
كذلك يعكس المناخ المنظمى التصورات الجماعية

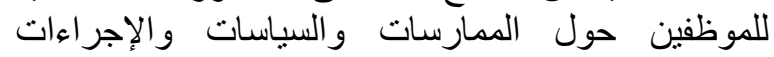

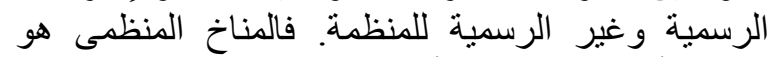

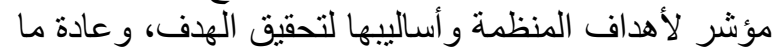

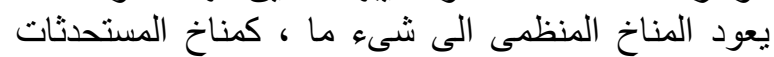

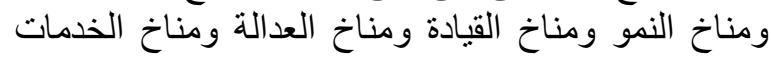

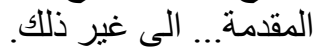

ولتحقيق الهذف من هذا البحث سوف ينظر الى مفهوم

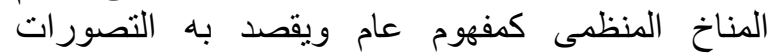
المشتركة للموظفين لكل من الإن السياسات و والممارسات و الإجر اءات التنظيمية الرسمية وغير الرسمية. . (Reichers and Schneider, 1990)

لفهم السلوك الانسانى المناخ المنظمى النظر اليه في سياق البيئة

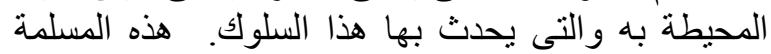

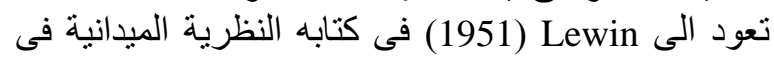

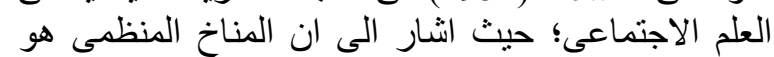

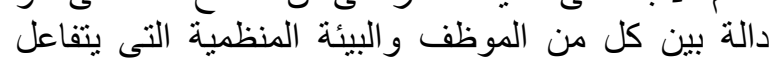

كما كان يُنظر إلى دمج المناخ فى أدبيات المنظمات

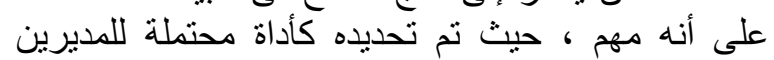

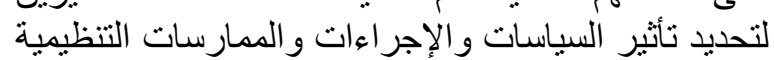

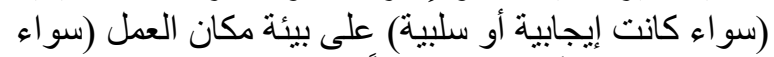

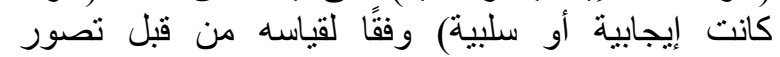
الموظفين) (Litwin and Stringer, 1968) .
بين مناخ المنظمة و أداء الموظفين من حيث الأداء التجارى

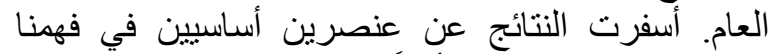

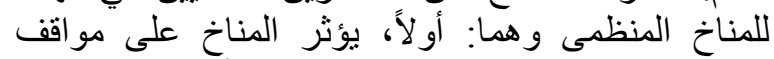

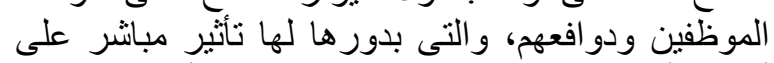

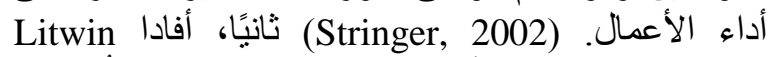

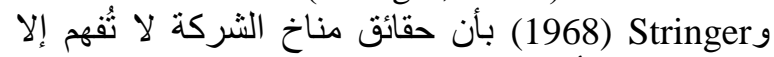

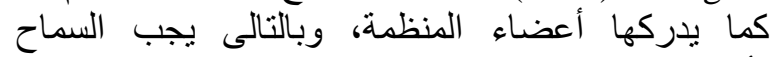

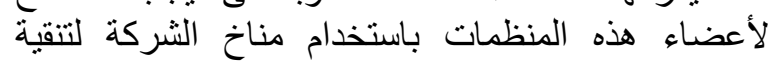
ظاهرة المناخ المنظمى من قبل هؤ لاء الموظفين.

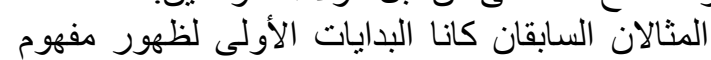

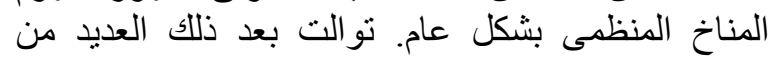

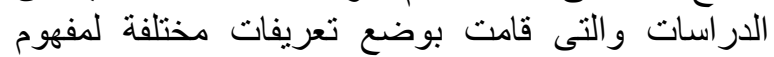

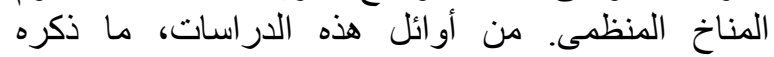

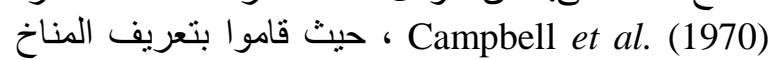

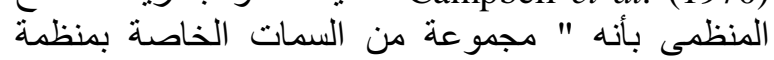
معينة والتى قد تنتج من الطريقة التى تتعامل بها التهات النظمة

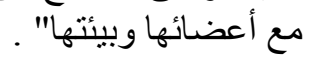

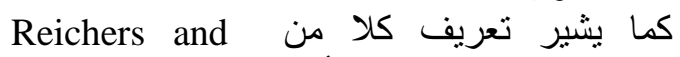
Schneider

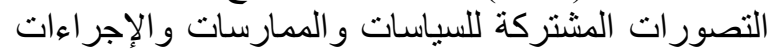

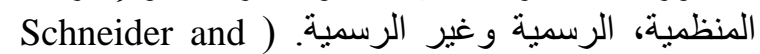

(Reichers, 1983 كما عرف Joyce and Slocum (1984)، المناخ

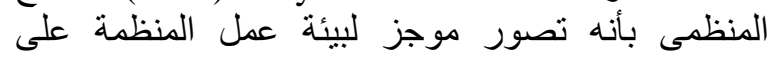

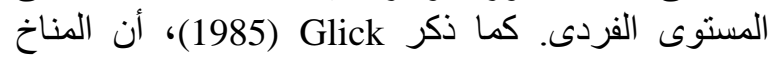

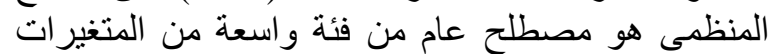
المنظمية؛ وليس النفسية؛ والذى يصف أفعال الفرد الفئ داخل المنظمة. - (المنظة

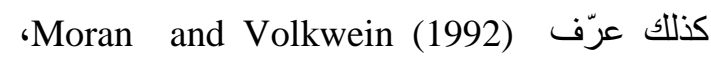

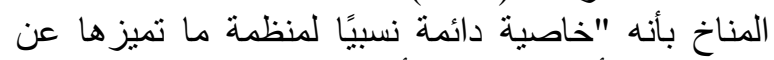

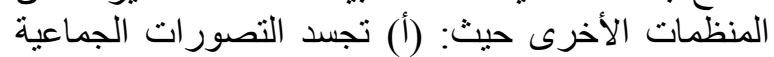

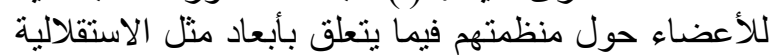

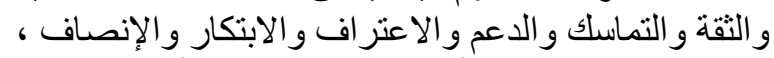

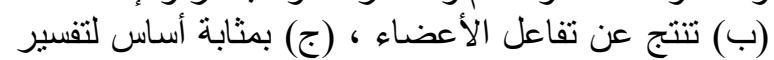

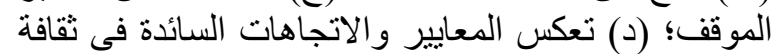

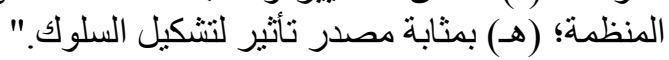

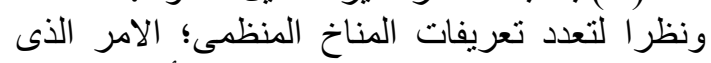

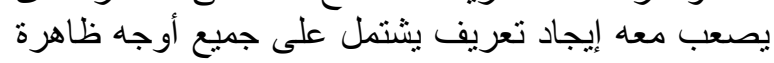

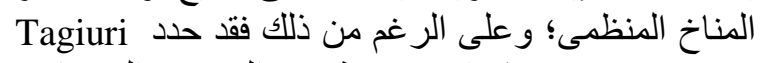
و et al., 1968

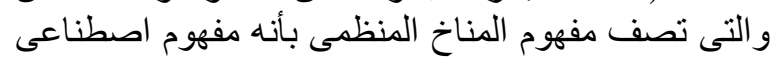

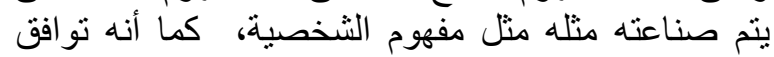

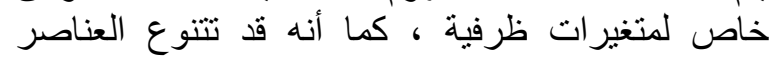

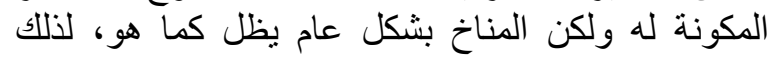

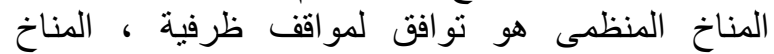

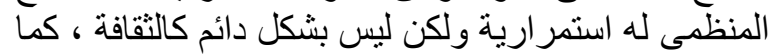

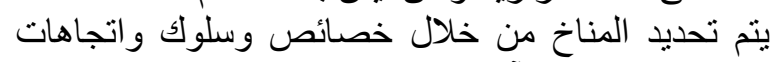

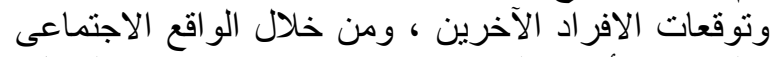

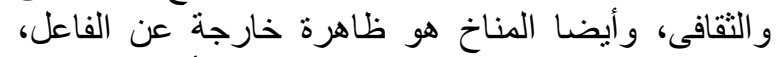
وعلى الرغم من ذللك، قد يشعر الفاعل بأنه يساهم في الفي 
عن المنظمة؛ وهى مجموعة من السمات الثابتة، ويمكن

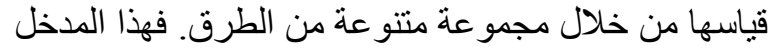

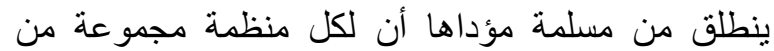

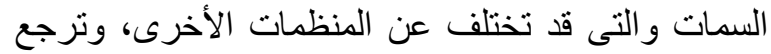

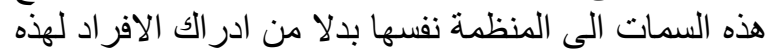

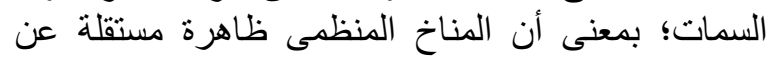

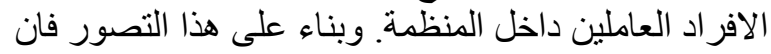

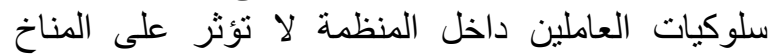

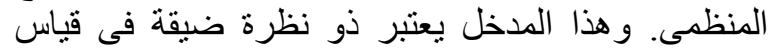

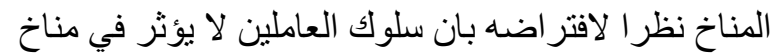

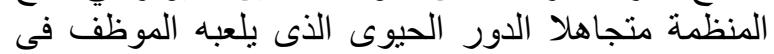

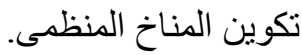

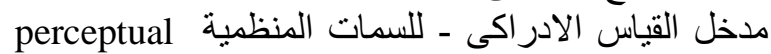
؛measurement- organizational attribute approach (يمكن أن يطلق عيه مدخل المناخ المنظمى) وهو ينظر

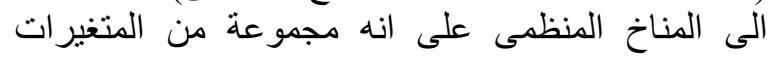

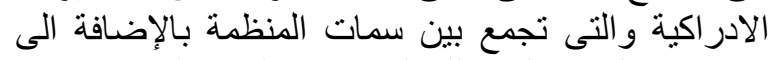

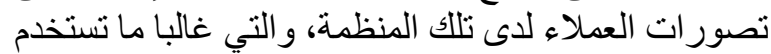
أسلوب مقياس ليكرت. perceptual مدخل القياس الادراكى ـ للسمات الفردية ؛measurement-individual attribute approach (يمكن أن يطلق عليه مدخل المناخ النفسى) و الذى يعرف النف

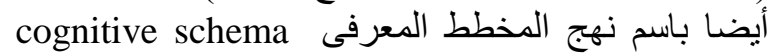
approach

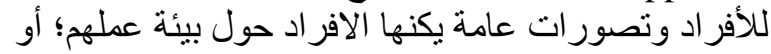

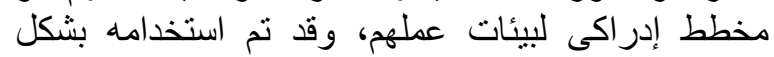

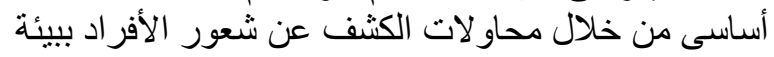

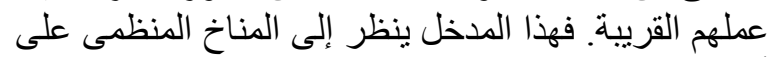

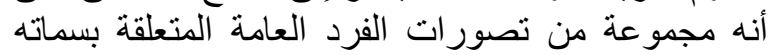

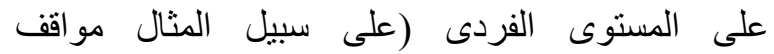
وسلوكيات الفرد فى مكان العمل) ، فهو تقييم الفرد ما هو هو في الفي

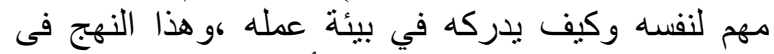

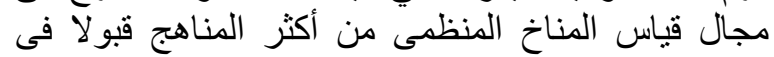

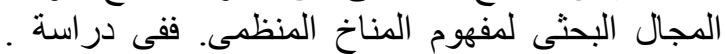
Schneider and Snyder, 1975)

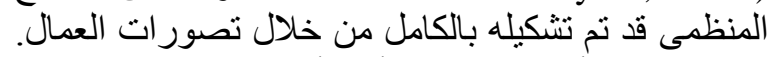

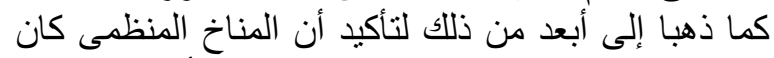

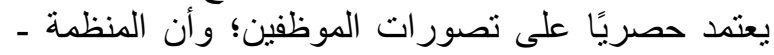

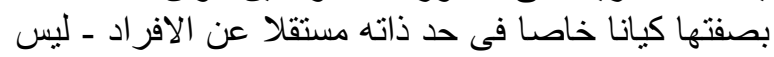

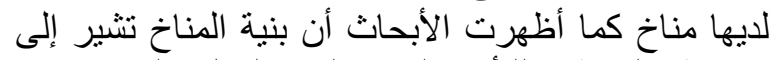

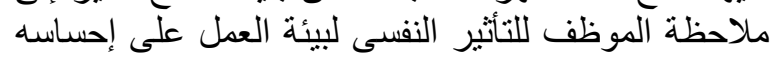
بالرفاهية. (James and James, 1989)

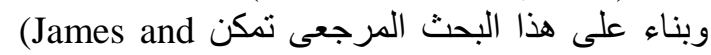

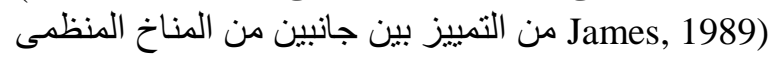

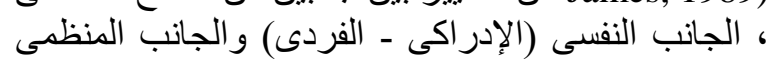

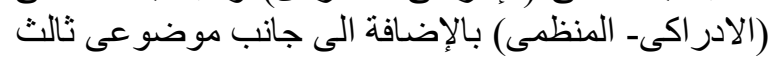

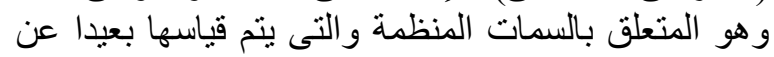

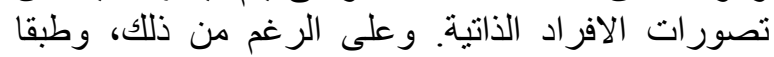

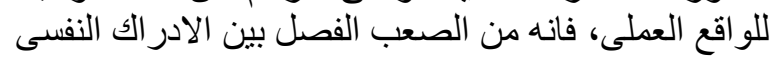
والذى بعبر عن ادراك الخصائص الفردية داخل الفين الادنظمة النفي person- وتعد نظرية ملائمة الفرد-المنظمة organization fit theory

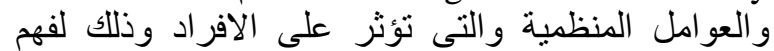
السلوك المنظمى. وكذللك لان الملائمة المنظمية تؤثر الأثر على مخرجات المنظمة. ( Chatman, 1989; Kristof-Brown فالخصائص الفردية قد تشتمل على سمات (et al., 2005

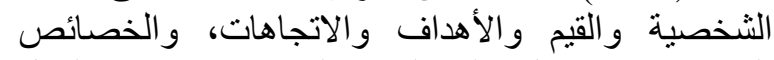

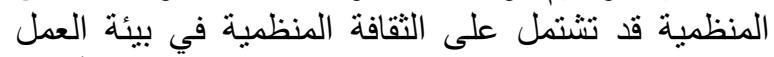

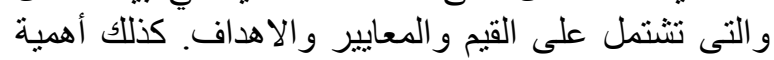

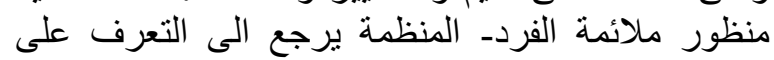

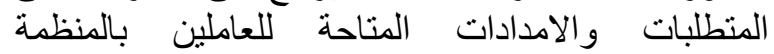

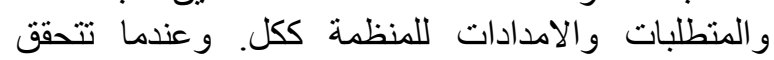

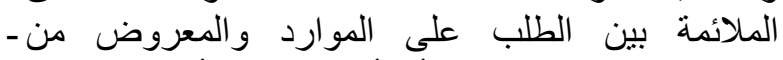

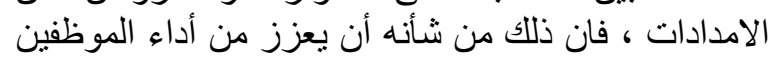

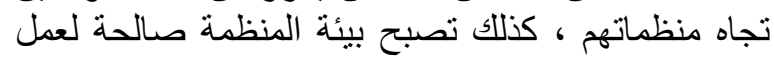

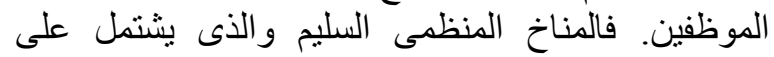

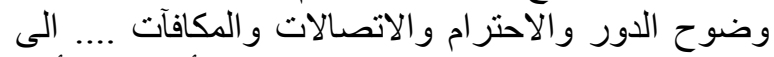

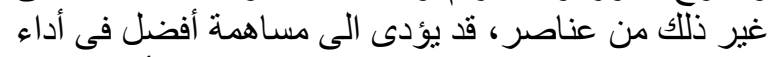

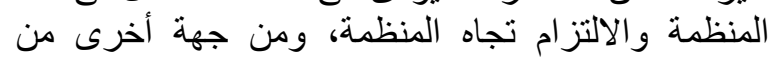

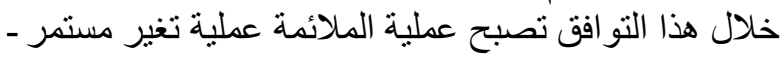

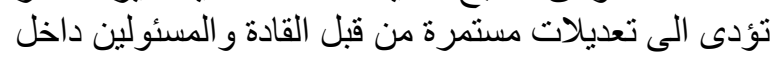

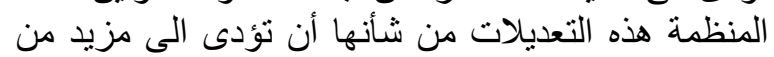
الملائمة مع قيم الموظفين.

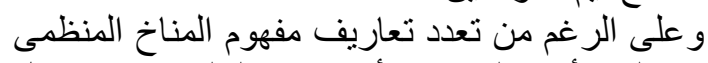

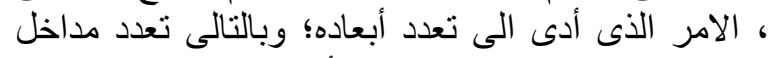

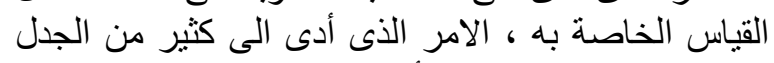

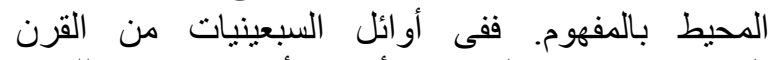

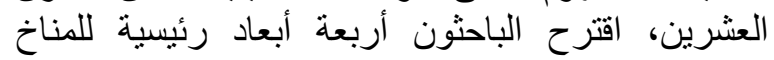

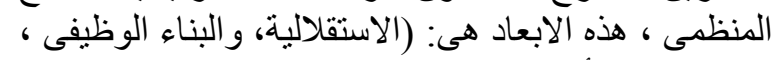

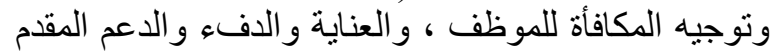
من قبل المنظمة (Campbell et al., 1970).

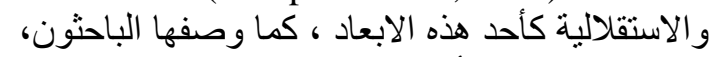

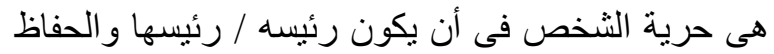

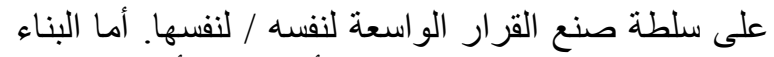

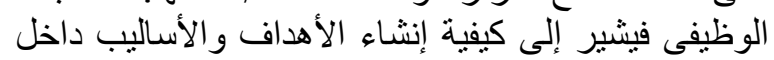

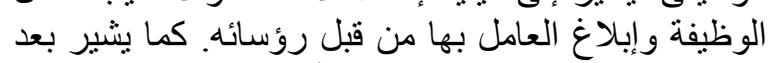

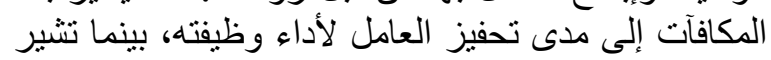

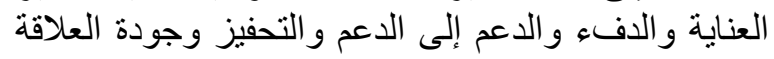
الثاملة من المنظمة والني يتم إدراكها. al., 1970) تلى ذلك بحث مرجعى عن الأبحاث التى أجريت فى التى

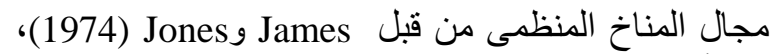
من أهم نتائج هذا البحث البن المرجعى تحديد ثلاثة مداخل

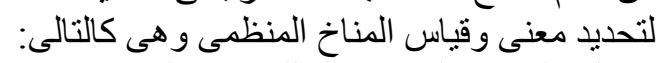

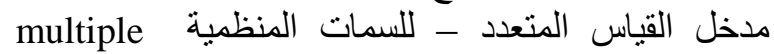
؛measurement - organizational attribute approach الذى ينظر الى المناخ المنظمى على انه مجموعة من

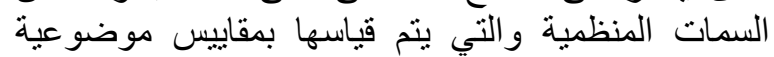

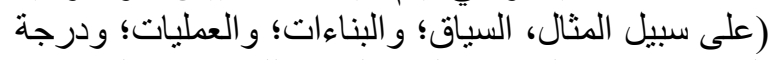
التعقدية؛ ونمط القيادة؛ و البيئة المادية للمنظمة ولئة و التى تعبر ودرئ 
وكذللك منظور البناء الاجتماعى Social constructionist

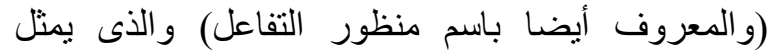

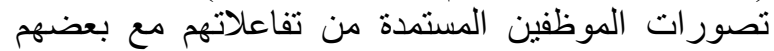

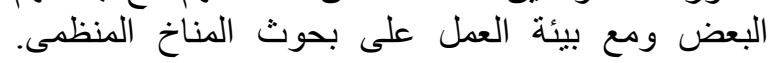
Burke et فقد العناخ (Schneider and Reichers, 1983) al 1992

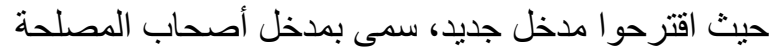

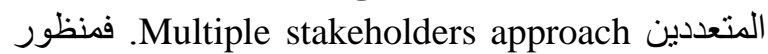
أصحاب المصلحة المتعددين بمثل امتدادًا لعمل James

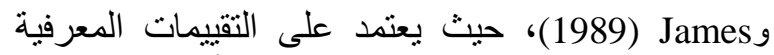

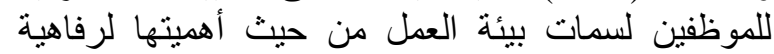

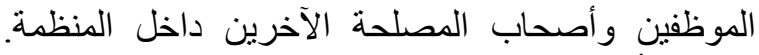

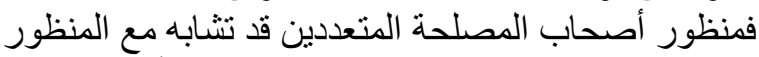

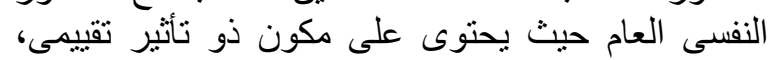

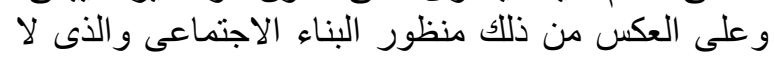
يحتوى على مكون ذو تأثثر تقييمى. ( Burke et al.,

بالإضافة الى المداخل السابق ذكرها؛ هناك مدخل

التصورات المشتركة Shared perceptions approach

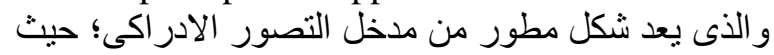

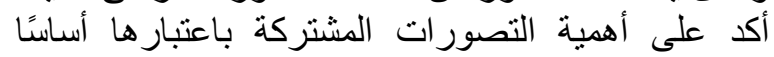

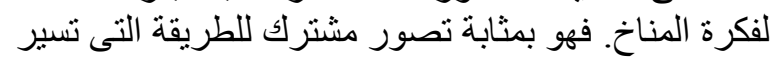

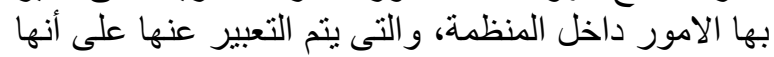

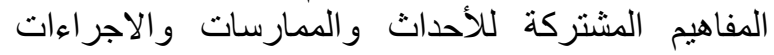

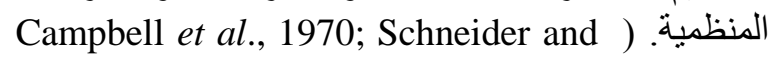

.(Reichers, 1983

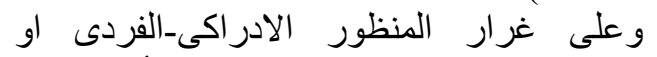

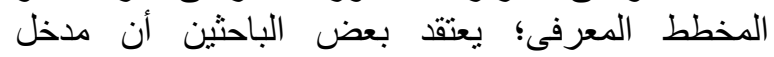

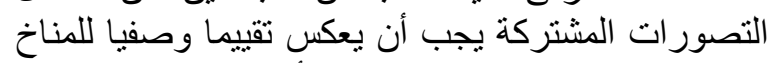

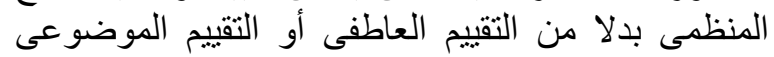

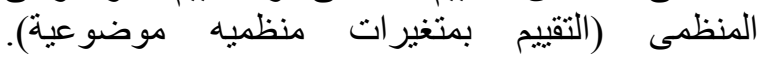
.(Schneider and Reichers, 1983)

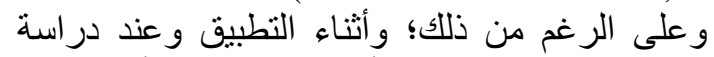

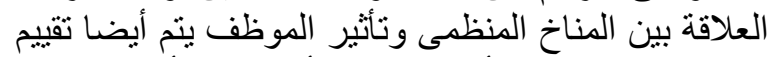

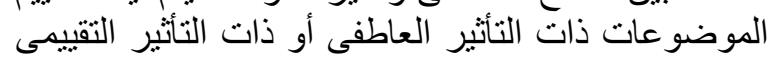
من خلال مقاييس المناخ المنظمى ذاتير العات المكون العاطفى التئى

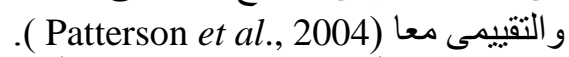

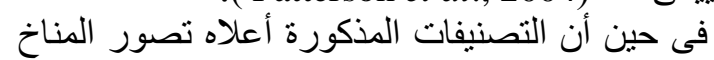

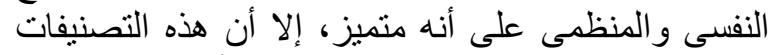

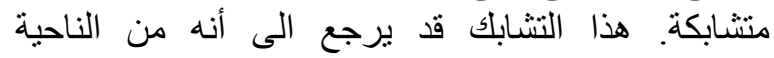

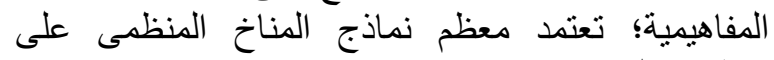

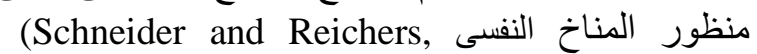

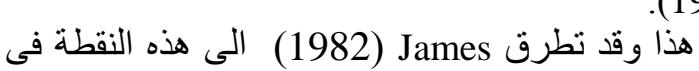

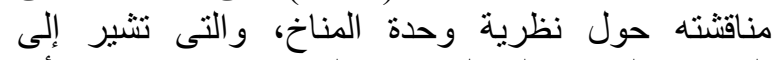

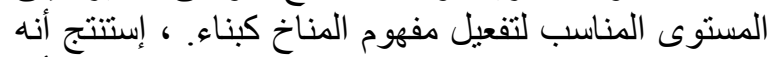

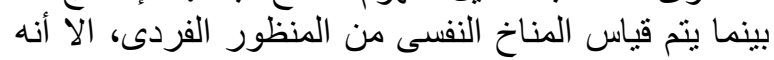

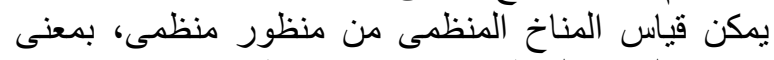

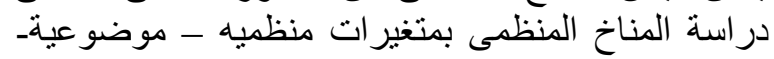
(على سبيل المثال، حجم المنظمة، الهيكل البنائى
والادر الك المنظمى لبيئة المنظمة والذى يعبر عن ادراك الك الكئه

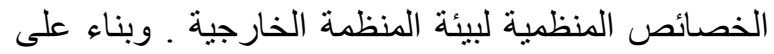

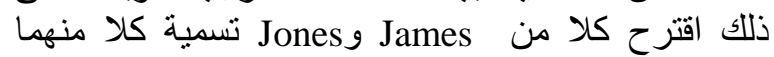
بالمناخ المنظمى المدرك من باك .Climate

Jذا الاطار التصنيفى الذى قدمه كلا من James

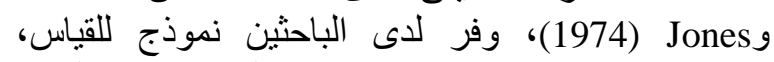

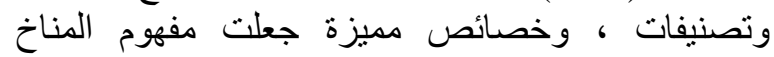

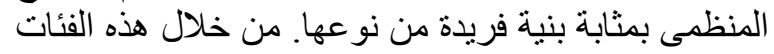

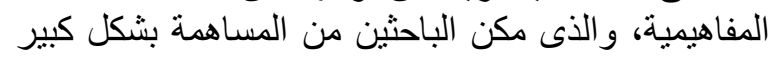

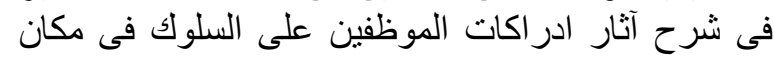

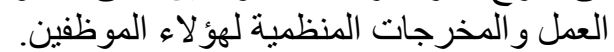

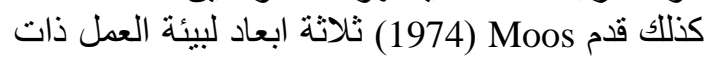

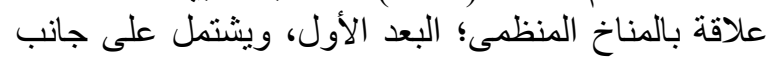

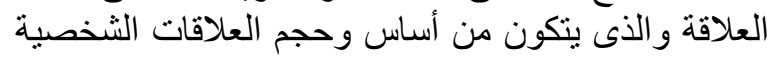

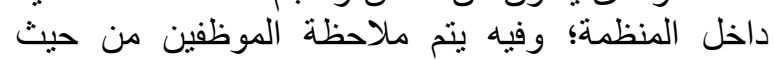

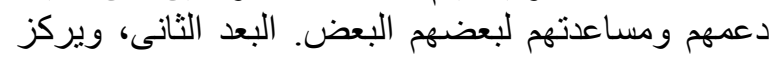

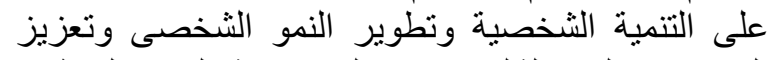

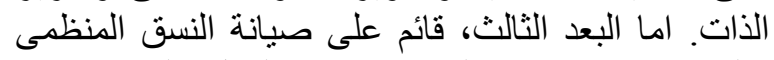

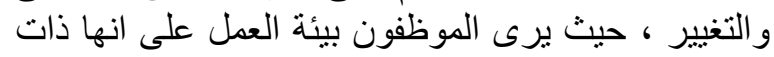

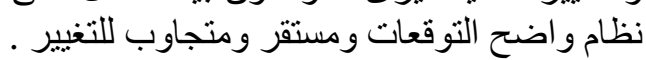

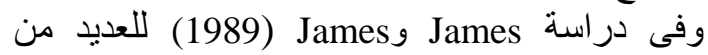

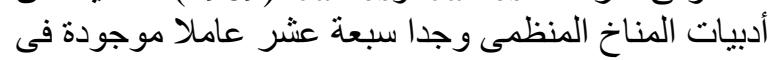
بيئة العمل. من هذه العو امل: (الاجهاد، و الاستقلالية، و والثقة

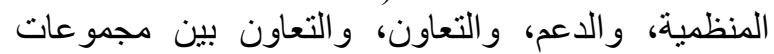

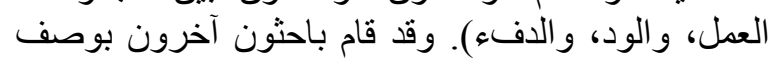

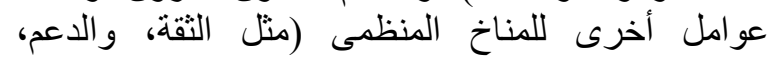

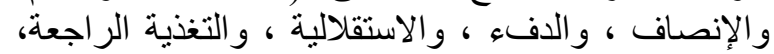

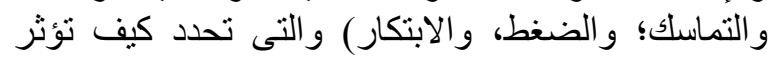

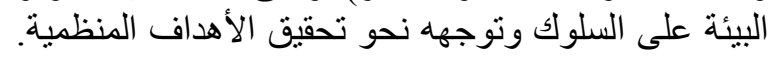
Koys and DeCotiis, 1991; and Rousseau and ) (Tijoriwala, 1998

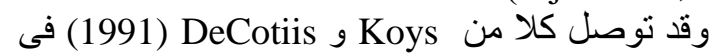

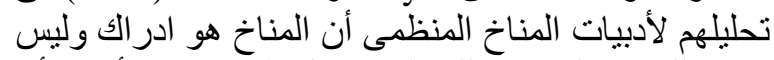

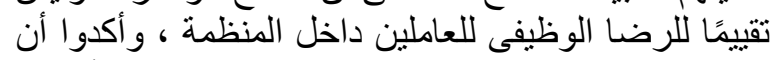

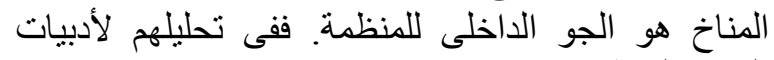

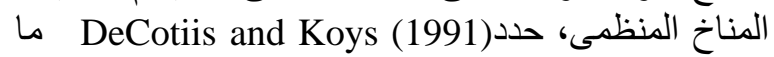

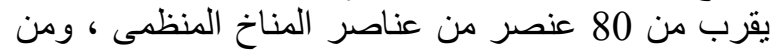

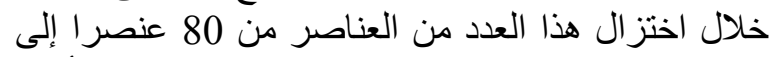

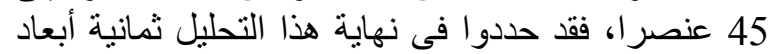

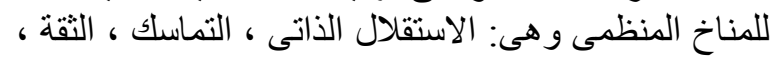

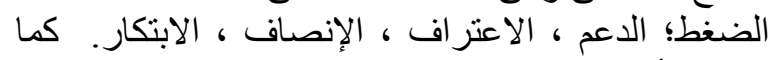

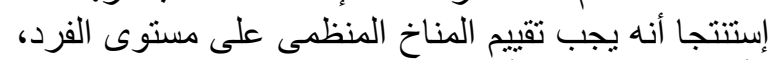

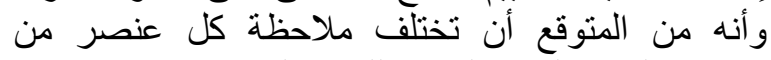
عناصر الفئات العامة الثمانية للمناخ الثناخ المنظمى. وعلى الرغم من هيمنة كلا من المناخ المنظور النفسى

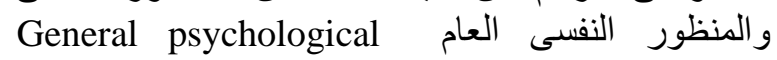
perspective

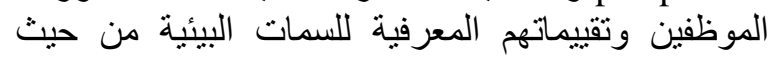

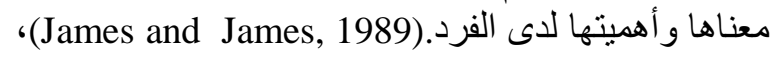


المر اد در استها؛ وكذللك طبيعة السلوك المر اد در استه داخل

هذه المنظمة. (Tagiuri et al., 1968)

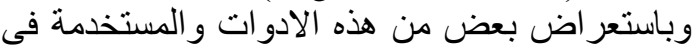

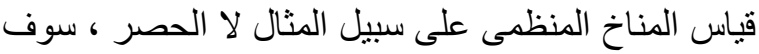

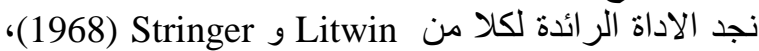

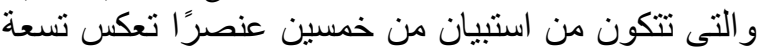

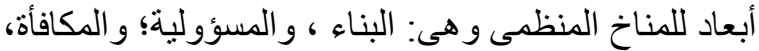

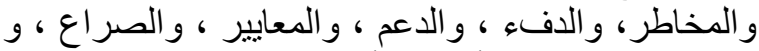

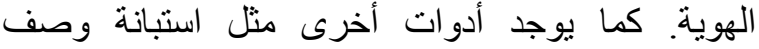
المنظمة. (House and Rizzo, 1972)، وكذللك مسح المنظمات Taylor and Bowers, 1972) S00 ) ، و أيضاح Payne (ليل المناخ الخاص بمنظمات الأعمال التجارية (and Pheysey, 1971 وكذلك فى دراسة Ostroff (1993)، تم اعتبار

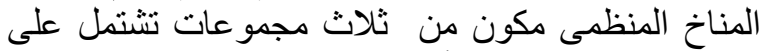

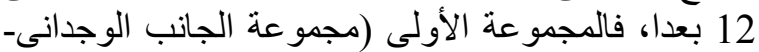

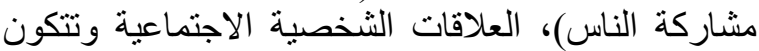
من (المشاركة ، الدفء ، المكافآنآت الاجتماعية ، التعاون).

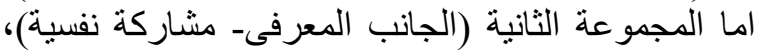

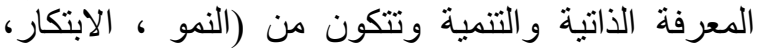

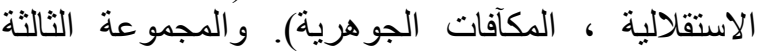

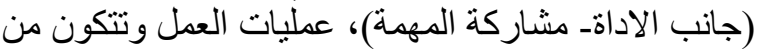

(التسلسل الهرمى، البناء ، المكافآت الخارجية ، الإنهات الإنجاز ).

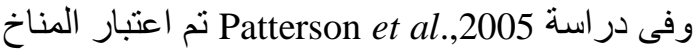

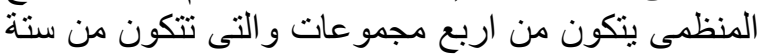

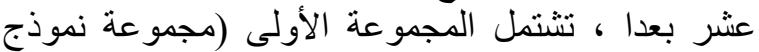

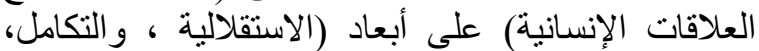

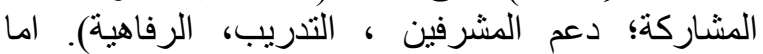

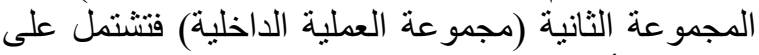

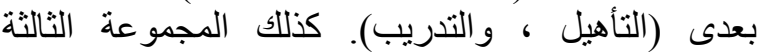

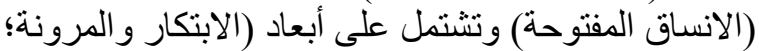

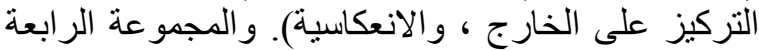

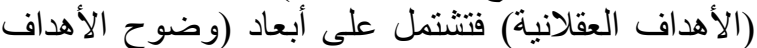

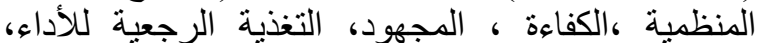

ضغط الإنتاج ، الجودة). مما سبق يتضح انه بينما أثشار بعض المضاج المؤلفين إلى انه

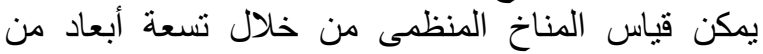

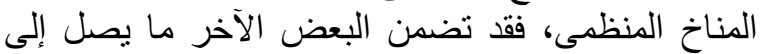

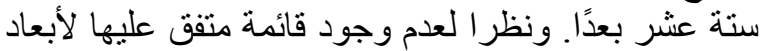

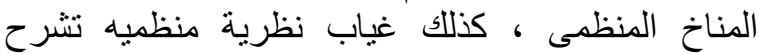
بوضوح أبعاد المناخ المنظمى ، فقد درس الباحثون المناخ

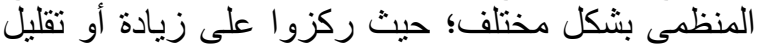
عدد الابعاد اكثر من التركيز على تطوير منظور والثيا واحد

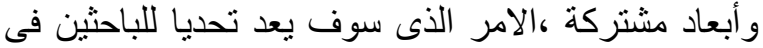

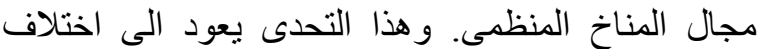
المنظمات من حيث الحجم ودرجة التهيثية التعقدية والتسلسل الهرمى للسلطة ورؤيتها ورسالتها ومنتجاتها وخدماتها وقيمها الى غير ذللك من أوجه اختلاف.

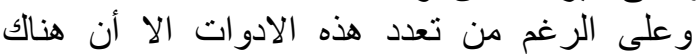
عائقان يشتركان فى كل هذه الأدوات وهما لادو ضعف الثات الثبات
للمنظمة... الى غير ذلك)، أو من خلال منظور الأفراد.

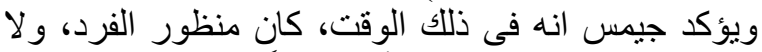
يزال، هو وحدة التحليل الأكثر قبولًا في دران دراسة المناخ

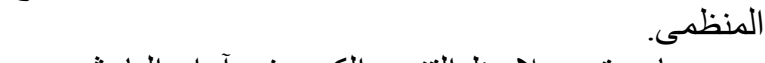

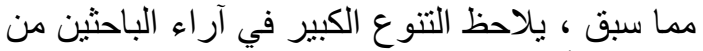

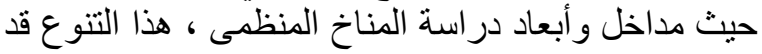

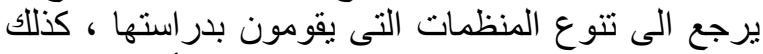

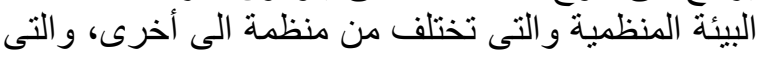
يعبر كل موظف عنها بقدر معرفته بهذه البيئة تبعا لوجهة التهنة

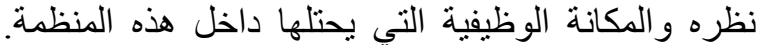

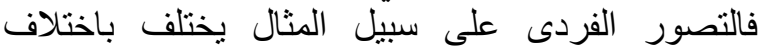
تصور ات الاخرين فى المنظمة ، وبالتالى سوف دؤن يؤثر هذا

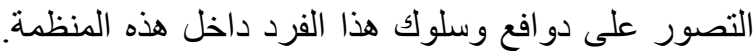

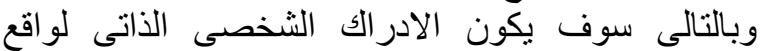

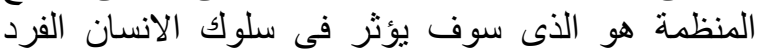

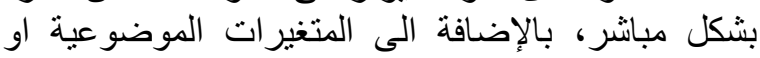

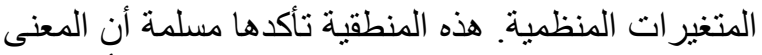

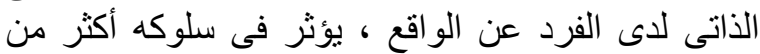

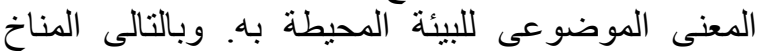

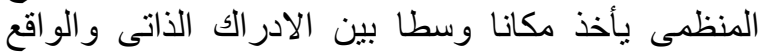

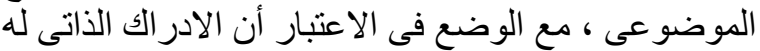
الوزن الأكبر من حيث الأهمية. فمن أهم توجهات الباحثين الادراكين هو (التوجه

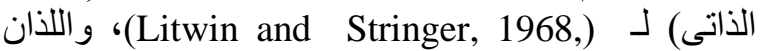

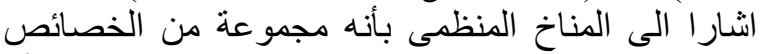

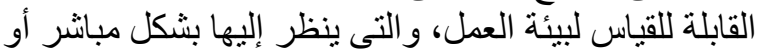

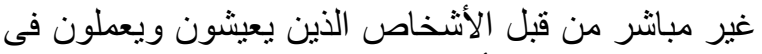

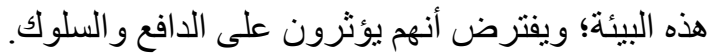

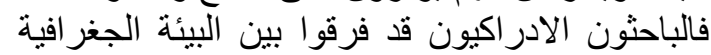

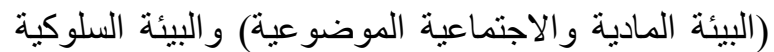

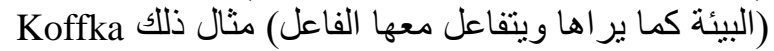

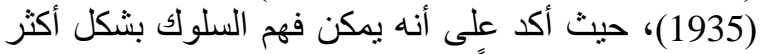

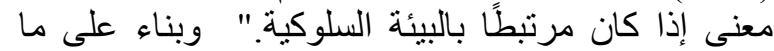

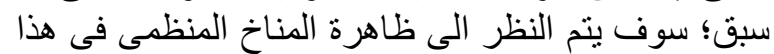

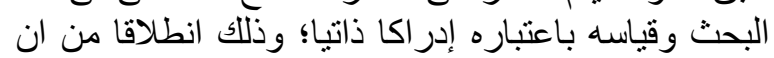

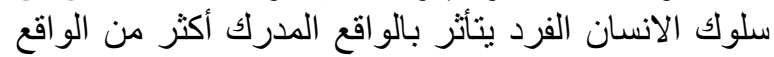

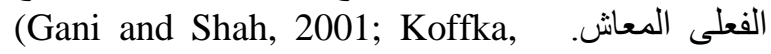

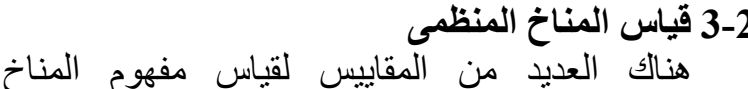

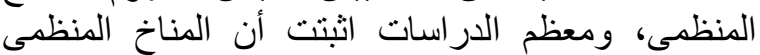

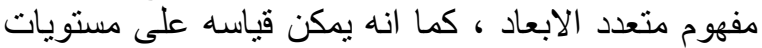

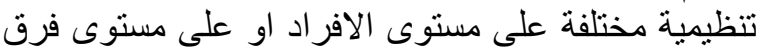

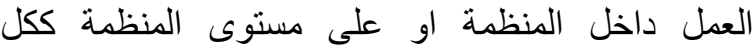
كوحدات تحليل متعددة. ولتعدد المداخل و الابعاد لمفهوم المناخ المنظمي،

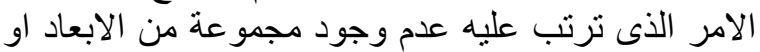

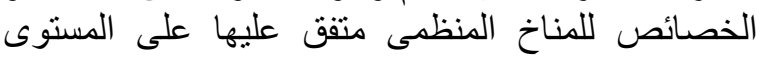

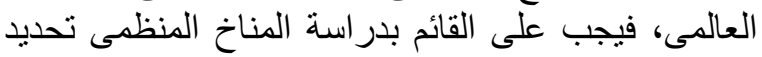

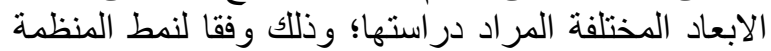


كذللك أوضحت بعض الدراسات أن هناك علاقة ارنباطية إيجابية بين المناخ المنظمى والرضي أرضا الوظيفى. (Danish et al., 2015; Jyoti, 2013; M. Patterson et al., 2004; Pritchard and Karasick, 1973; Schnake, 1983; Schneider and Snyder, 1975; Schyns et al., 2009; Shafer, 2009; Tripathi and . (Tripathi, 2002 كما وجدت علاقة بين المناخ المنظمى و أثنكال الاداء

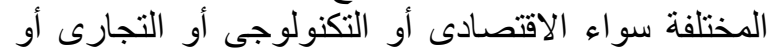
الاجتماعى (Bartram et al., 2008). كذلك وجدت الأن علاقة الأن بين الأداء الفردى للعمل. ( Brown and Leigh, 1996) (Pritchard and Karasick, 1973) كذللك أيضا وجدت علاقة بين المناخ المنظمى والأداء المنظمى.

(Kangis et al., 2000; Lawler et al., 1974; Mullins and Christy, 2010; Patterson et al., 2004; Raza, 2010; Vashdi et al., 2013).

كما تم اكتشاف مفاهيم منل الرضا الوظيفى، والحاجة الاجة

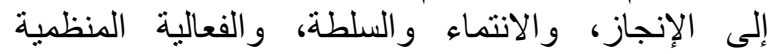

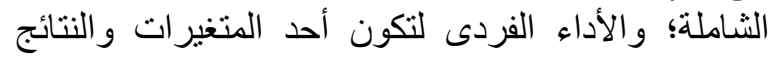

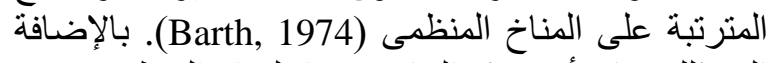

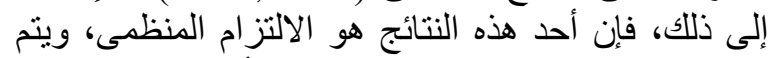

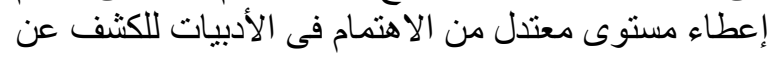

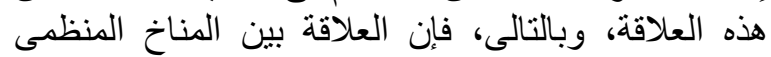

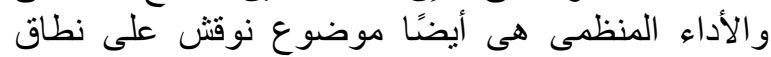

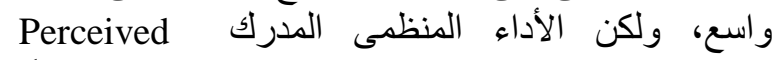
Organizational Performance (Berberoglu, وم يلفت الانتباه إلى نفسه حتى الآن .2018; Khan, 2019 ووفقًا ل Mullins (2010)، هناك وكلام علاقة كبيرة بين

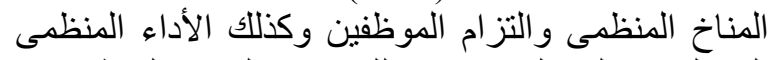

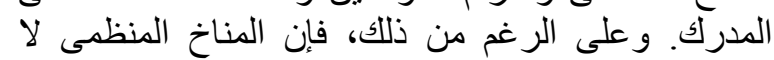

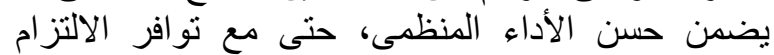

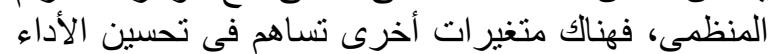
. (Berberoglu, 2018; Mullins and Christy, 2010) كذلك هناك العديد من الدراسات و التى قامت بدراسة

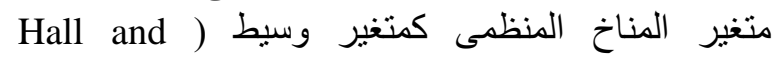
Schneider, 1973; Likert, 1961 المناخ المنظمى كمتغير وسيط بين المشاركة فى العمل

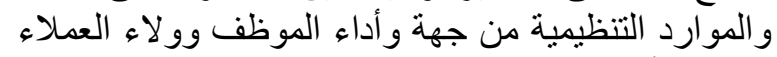

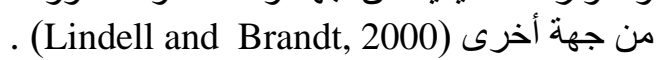
كذلك انطلاقا من مسلمة ان احتباجات الانسان الفرد المنان

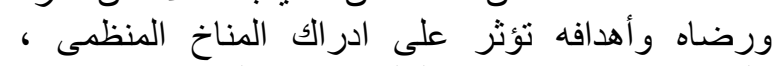

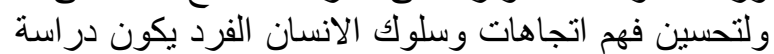

المناخ مساعد في هذا الفهم (Pace and Stern, 1958).

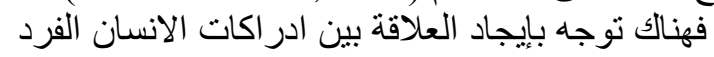

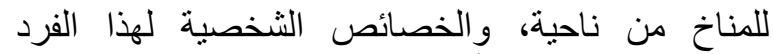

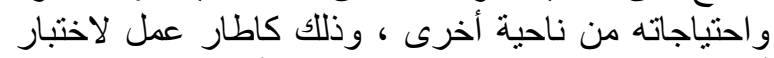

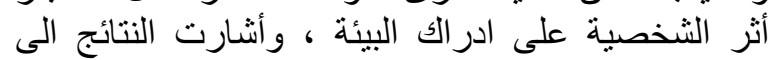
وجود القليل من التداخل بينهما (Stern, 1970).
الداخلى ومصداقية البيانات (الخصائص السيكومينرية غير

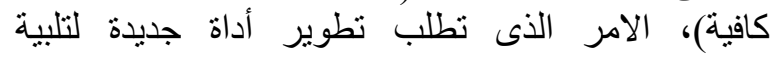

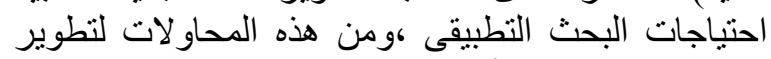

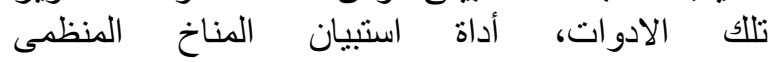
Organizational Climate Questionnaire (OCQ) لكلا من (Farnham and Goodstein, 1997) ، و وهذه الأداة سوف يتم استخدامها فى هذا البحث لمر اعاة كلاهما ،

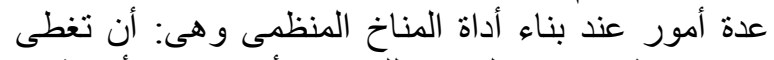

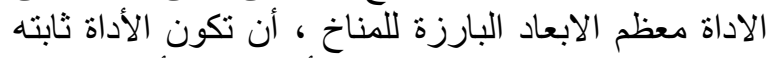

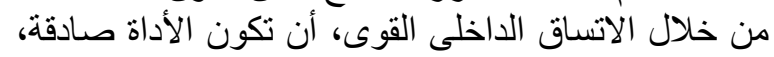

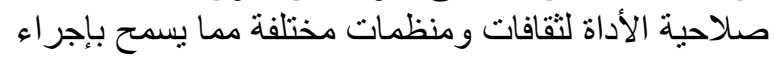

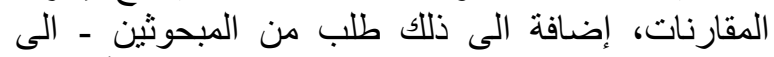

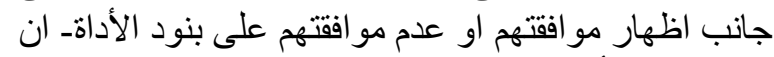
يحددو ا مدى أهية كل بند من هذه البنود بالنسبة اليهر.

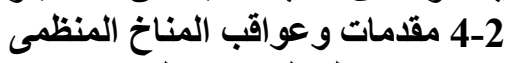
من خلال التعرف على بلى بعض تعات العاريف مفهوم المناخ

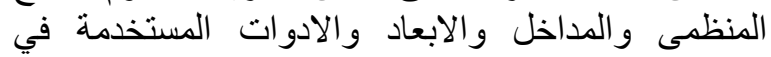

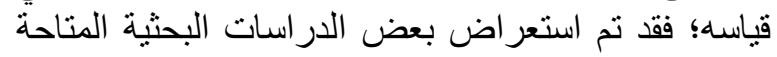

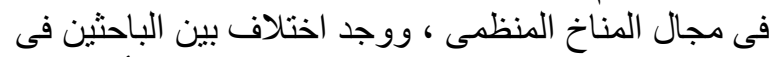

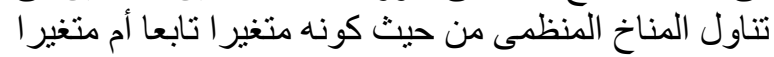
مستقلا ام متغير اوسيطا.

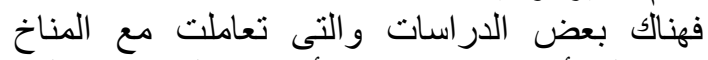

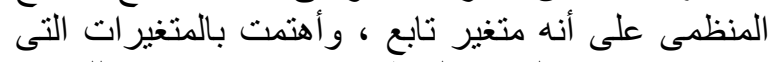

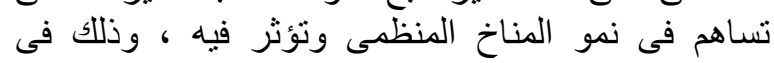

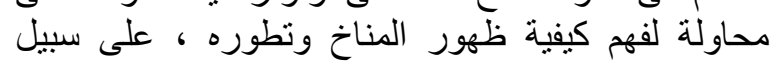

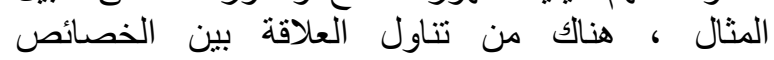

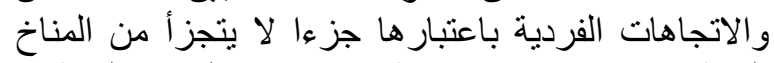

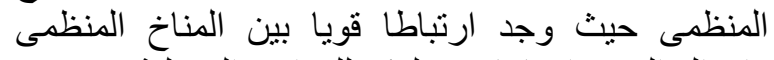

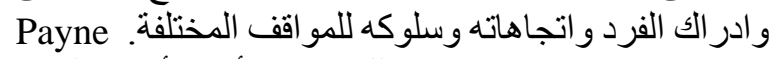

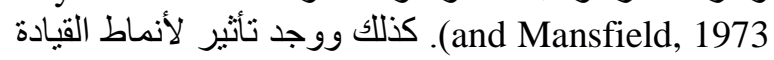

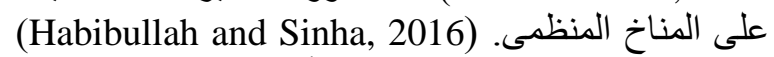

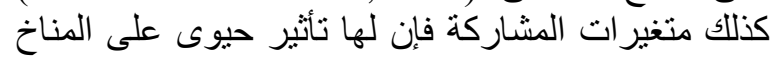

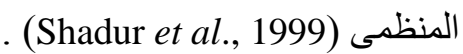
بالإضافة الى العديد من المتغيرات الاخرى؛ والتى التى

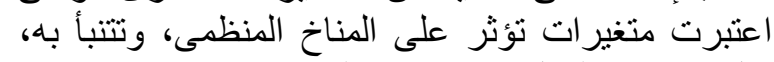

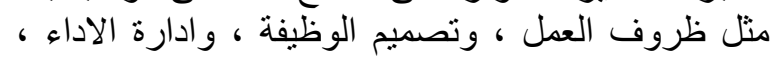

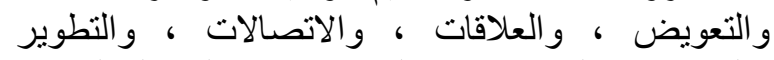

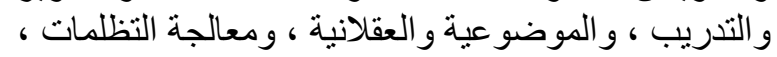

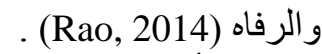
كما أن هناك العديد من الدر اسات و التى تناولت مفهوم

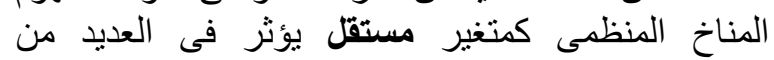

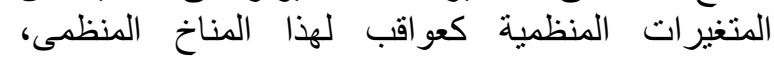

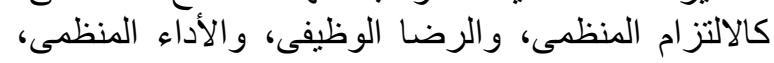

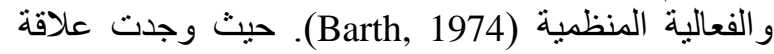
ارنباطية ايجابية بين المناخ المنظمى والالتزام المنظمى. Arora et al., 2012; Danish et al., 2015; DeCotiis ) and Summers, 2016; Jyoti, 2013; Mullins, 2010; Nammi and Nezhad, 2009; Reddy et al., 2000; .(van den Hooff and de Ridder, 2004 
المهام الوظيفية الرسمية واللافعالية المنظمية). ويوضح

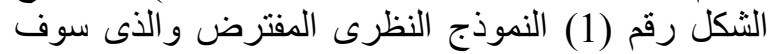
يتم اختباره فى هذا البحث.

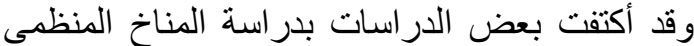

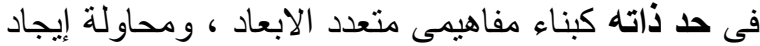

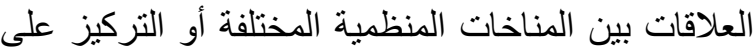

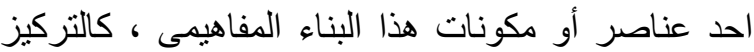

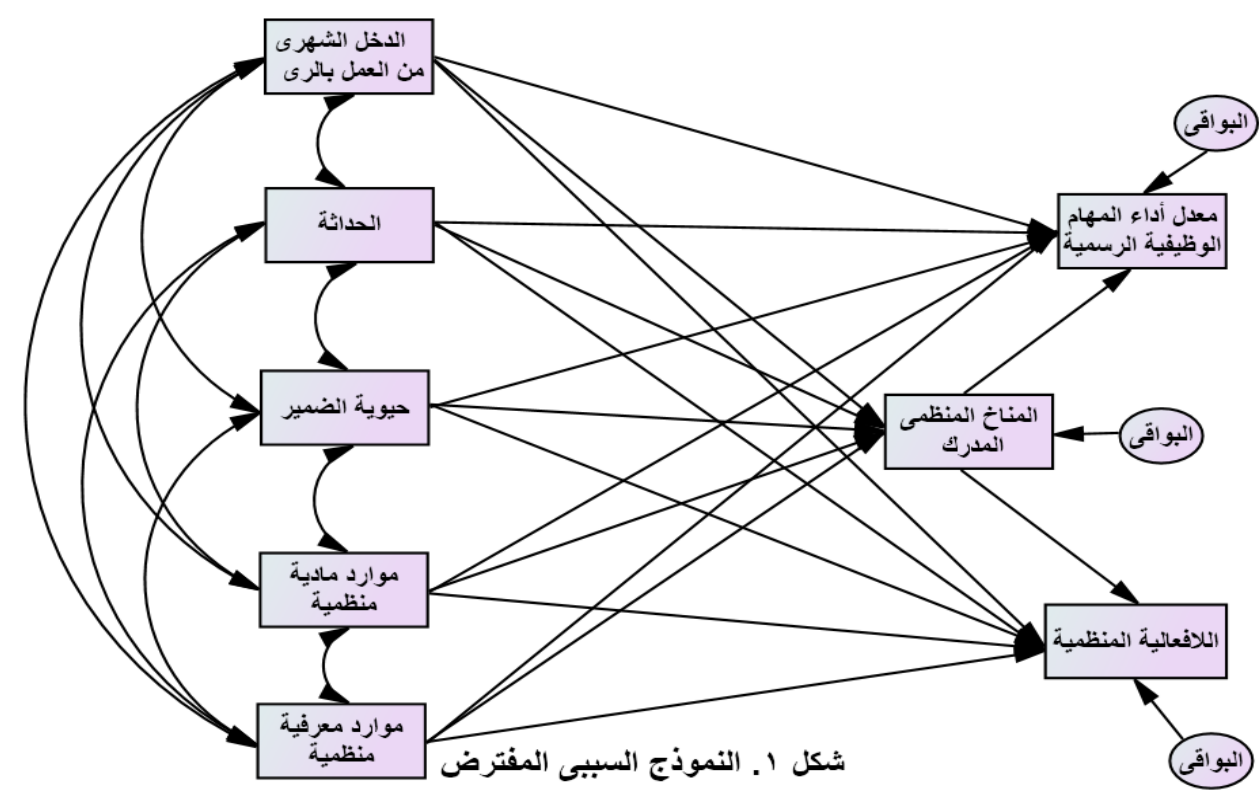

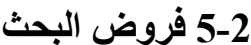

بناء على استعر اض بعض بعض التعاريف و المداخل الخاصة بالمناخ المنظمى وكذللك كيفية قياسه، وبعض أنس أمثلة

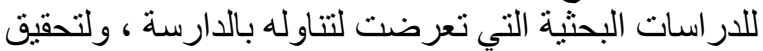
أهداف هذا البحث يمكن صياغة الفروض البحثية البية التالية لاختبار صحة العلاقات الارتباطية المتعددة؛ وذللك بعد وضعها في صورتها الصفرية كالتالى: الفرض البحثى الأول: هناك علاقة ارتباطبة متعددة بين كل

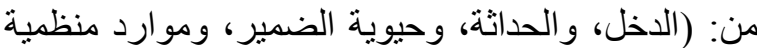
مادية، وموارد منظمية معرفية) و المناخ المنظمى ولية المدرك.

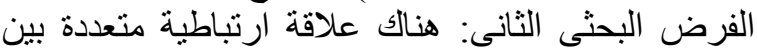

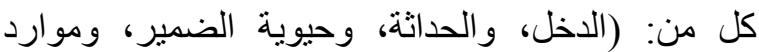

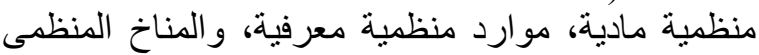
المدرك) ومعدل أداء المهام الوظيفية الرسمية. الفرض البحثى الثالث: هنالك علاقة ارثباطية متعددة بين

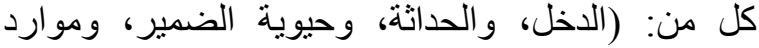

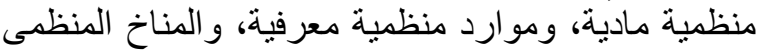
المدرك) و اللافعالية المنظمية.

\section{3- الطرق والأساليب البحثية}

1-3 المبحوثون

لتحقيق أهداف هذا البحث تقرر اعتبار المجتمع البحثى هو عينة هذا البحث، والذى يشتمل على جلى جميع

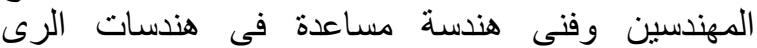

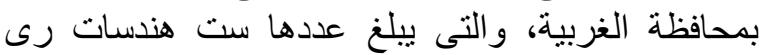

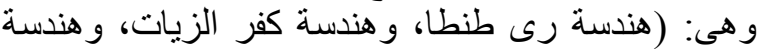

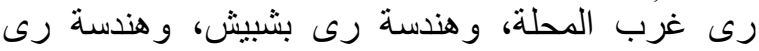

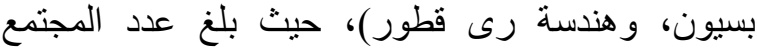

على در اسة عنصر المستحدثات، أو عنصر الصر اعات، الى غير ذلك من الأوجه المتعددة للبناء المفاهيمى لظاهرة

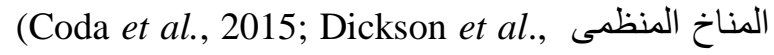
2006; James and James, 1989; Patterson et al., 2005; Peña-Suárez et al., 2013). وبناء على ما تقدم من أدبيات سواء على مستوى

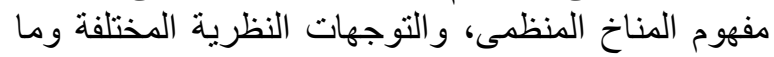

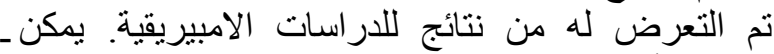

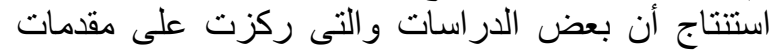

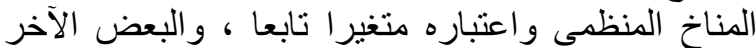

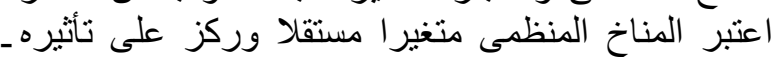

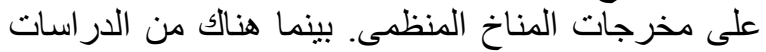

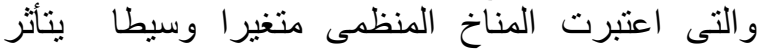

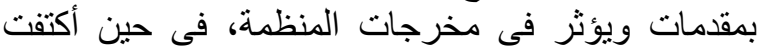

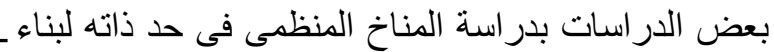

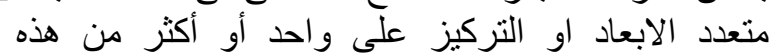
الابعاد. و انطلاقا من مسلمة ان الظاهرة الناد الاجتماعية بشكل

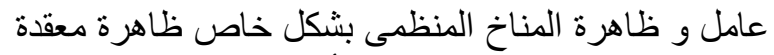

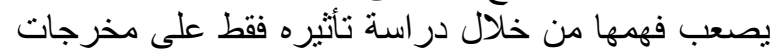

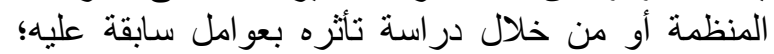
سوف يتم اعتبار المناخ المنظمى فى هذا البحث منغيرا وسيطا بلعب دورا مهما داخل المنظمة من خلانل تأثره ببعض المتغيرات الثخصية والاجتماعية الديمو غر افية دانية

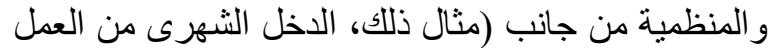

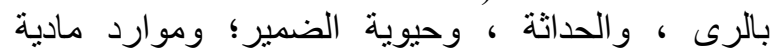
منظمية؛ موارد معرفية منظمية)؛ ومن جانب آلرية آخره تأثيره

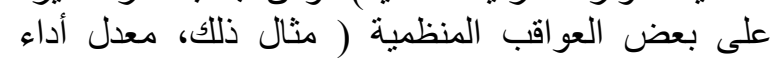




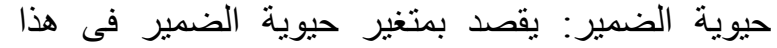

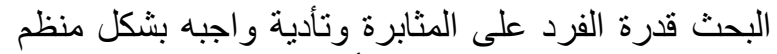

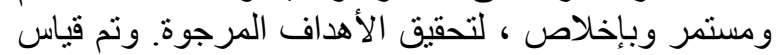
حيوية الضمير كأحد سمات الثخصية الخمس الثمس الكبرى

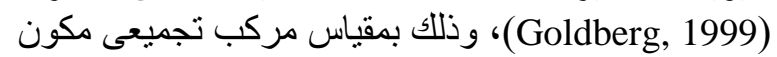
من ثلاثة بنود، وطلب من المبحوث الاختيار من بين ولاكين

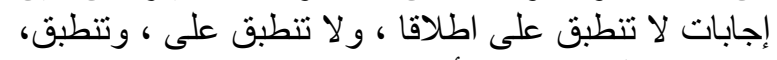

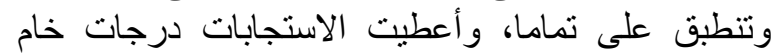

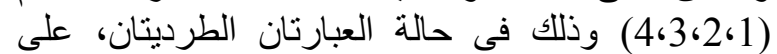

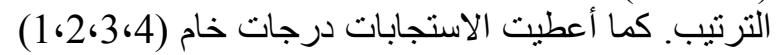

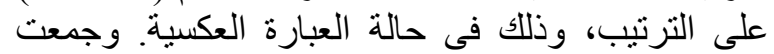

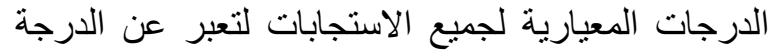

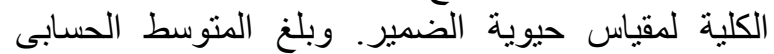

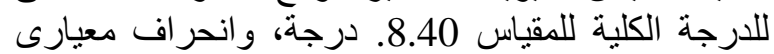

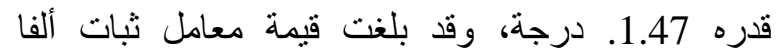

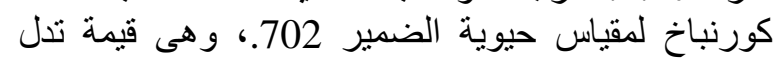

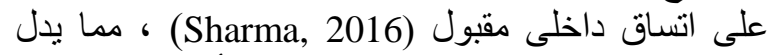
على صلاحية المقياس للاستخدام في أغرلى اضلى البحث العلمى فى هذا البحث. مو ارد مادية منظمية: يقصد بمتغير موالية ارد مادية منظمية

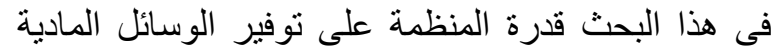

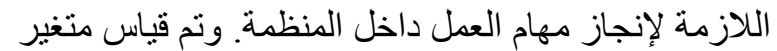

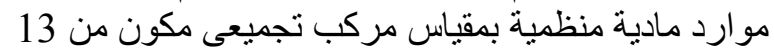

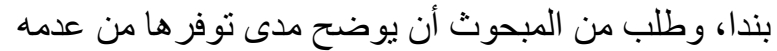

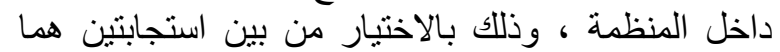

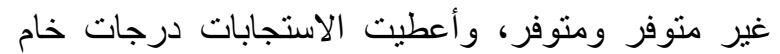

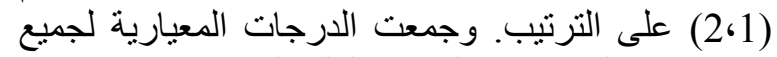

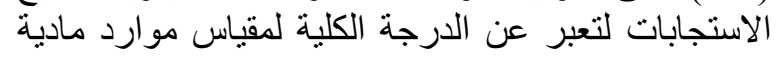

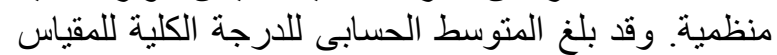

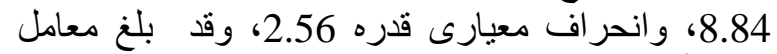

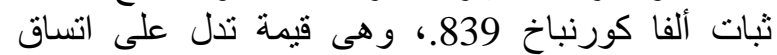

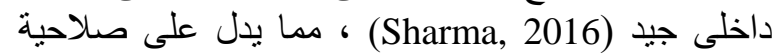
المقياس للاستخدام فى أغراض البحث العلمى فى هذا

موارد معرفية منظمية: يقصد بمتغير موارد معرفية

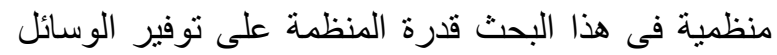
المعرفية اللازمة لإنجاز مهام العمل داخل المنظمة المنظمة كخطة

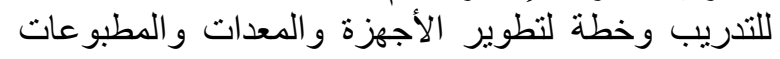

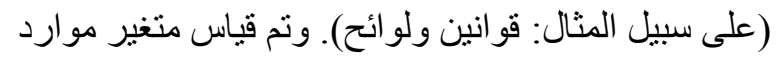

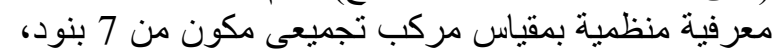

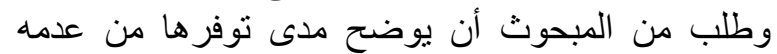

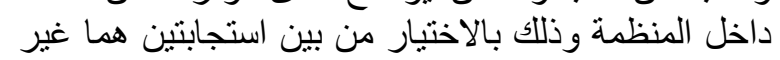

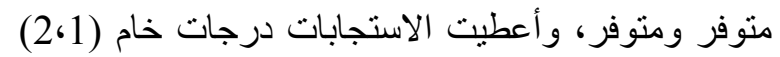

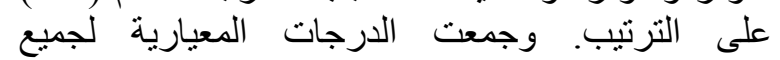

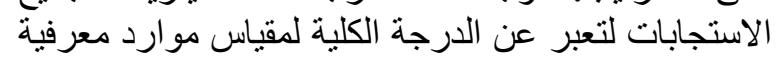

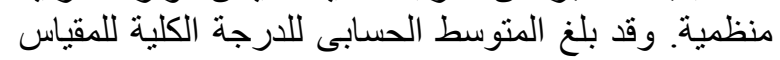

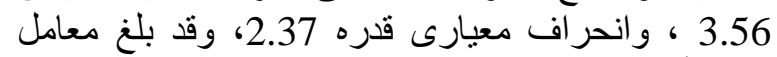
ثبات ألفا كورنباخ 896. داخلى جيد (Sharma, 2016) ، مدات الفا يدل على بلى صلاحية
البحثى في تللك الهندسات 18 مهندسا، و206 فنى هندسة - الإدة مساعدة؛ بإجمالى 224 مبحوث ( الادئى

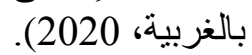
2-3 الإجراءات

جمعت بيانات هذا البحث فى الفترة من شهر يناير

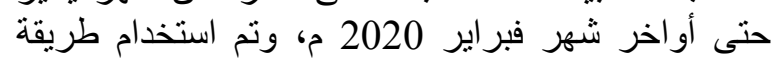

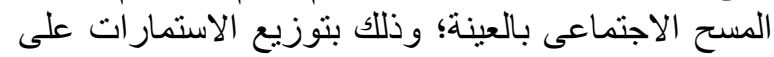

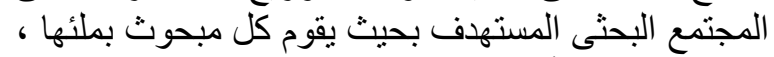

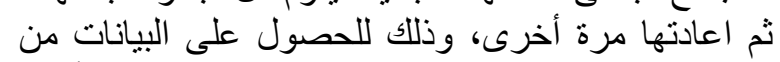

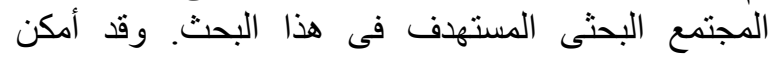

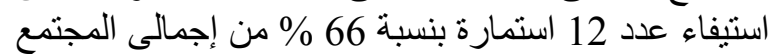

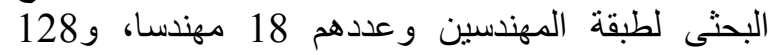
استمارة بنسبة 62 \% تقريبا من إجمالى المجتمع البحثى وعنى

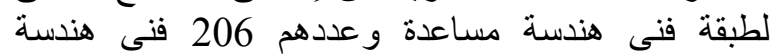
مساعدة، ليصبح العدد الكلى لعينة المجتمع البحثى 140

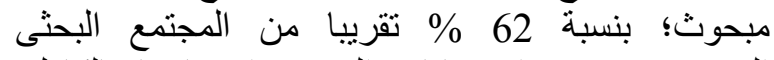

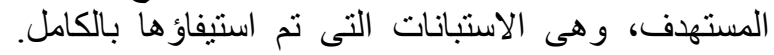

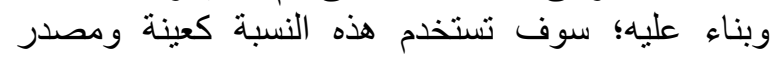
للبيانات فى هذا البحث؛ وذلاء لتك لتحقيق اهدافه. هذا وقد سبق تللك الاجراءات اعداد التاد استمارة لجمع -

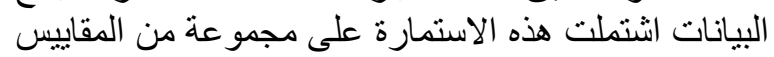

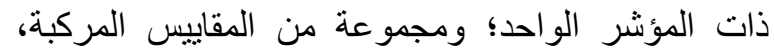

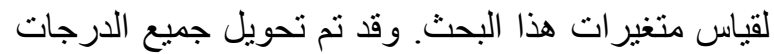

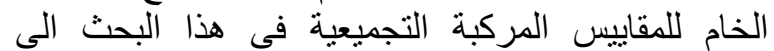

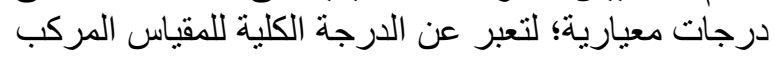

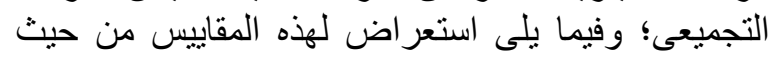

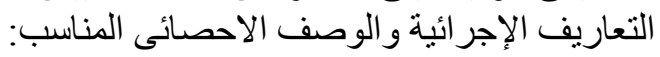

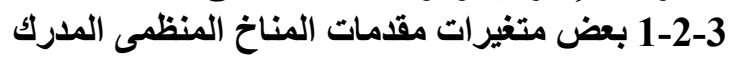

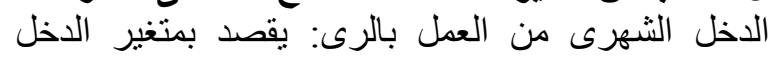

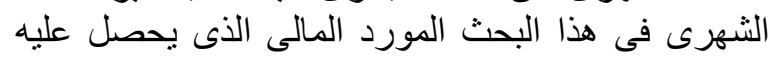

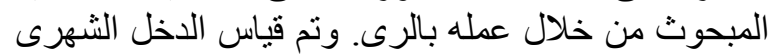

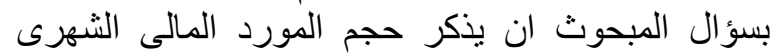
مقدرا بالجنيه المصرى، وقد بلغ المنوسط الحسابى للإخل

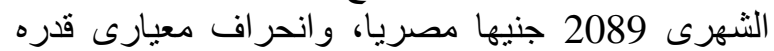

666.76 جنيها مصريا. الحداثة: يقصد بمتغير الحداثة فى هذا البحث نمط من الأداء

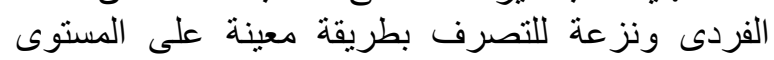

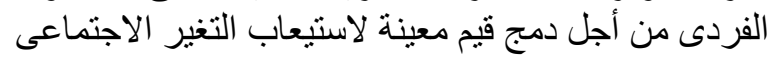

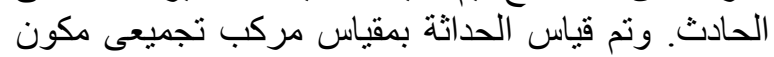

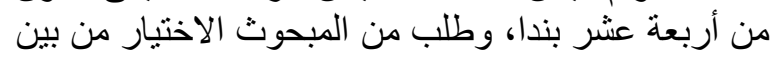

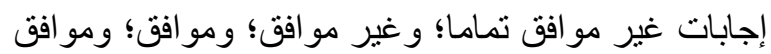

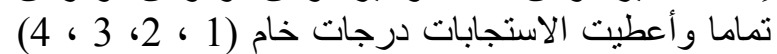

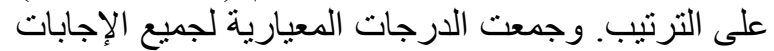

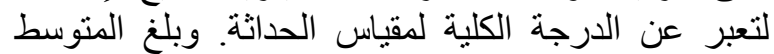

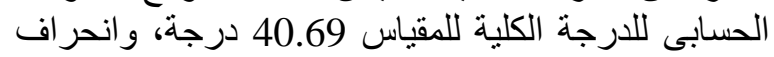

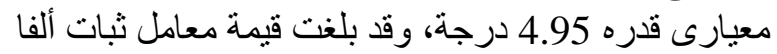
كورنباخ للمقياس 812.

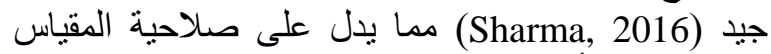
للاستخدام فى أغر اض البحث العلمى فى هذا البحث. 
لمعدل أداء المهام الوظيفية اليومية 1.41 وحدة، و انحر اف معيارى قدره 1.03 و وحدة.

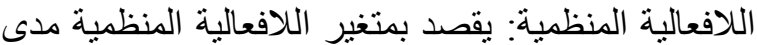

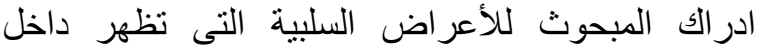

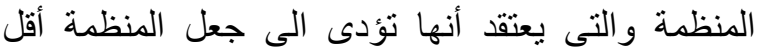

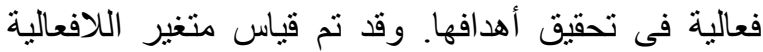

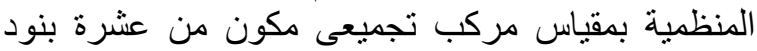

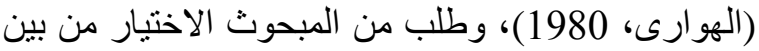

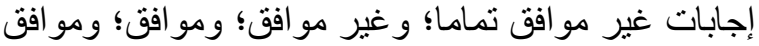

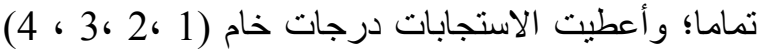

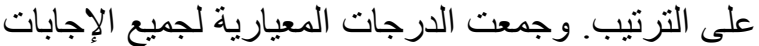

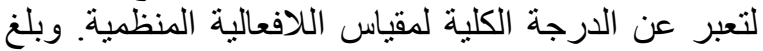

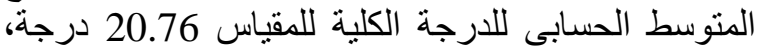
و انحر اف معيارى قدره 4.31، وقد بلدي بلغت قيمة معامل ثبات ألفا كورنباخ لـقياس 816 8.

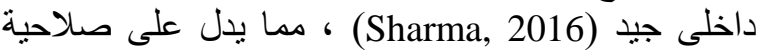
المقياس للاستخدام فى أغراض البحث العلمى فى هذا البحث.

4-2-3 بعض متغيرات الخصائص الاجتماعية_المنظمية

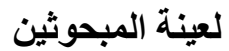

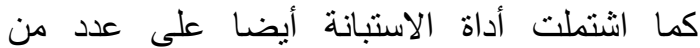
المقاييس لقياس بعض الخصائص الاجتماعية- المنظمية الإنية

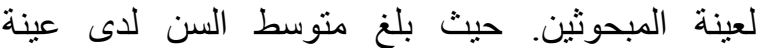
المبحوثين43.21 سنة، وانحر اف معيارى قدره 6.37 سنة كذلك بلغ المتوسط الحسابى لعدد سنوات الخبرة لدارئ لداى عينة هذا البحث 21.21 سنة، و الحر افت معيارى قدره 6.37

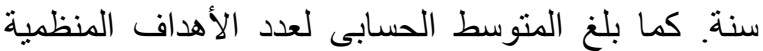

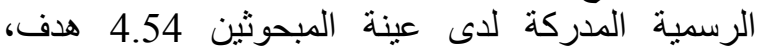
و انحر اف معيارى قدره 1.88 هدف. كذلة اللك بلغ المتوسط الحسابى لعدد المهام الوظيفية الرسمية 1.41 مهمة المية،

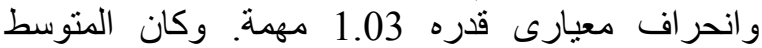

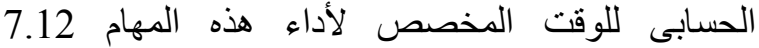

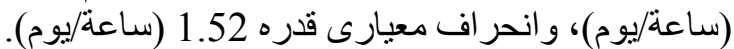
كذلك كانت فئة المنو ال لمتغير النوع النو الاجنماعى لعينة

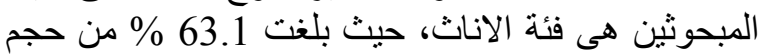

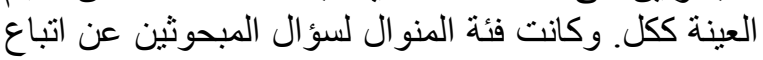

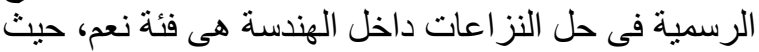

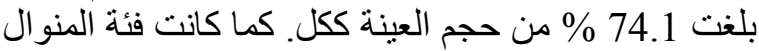

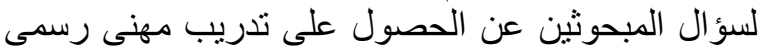

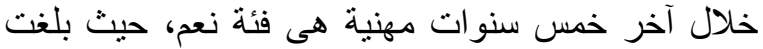
56.10 \% من حجم العينة ككل. بالإضافة الى ذلى ذلك كانت معظم آراء عينة المبحوثين فيما بتعلق بأهمية الأداء

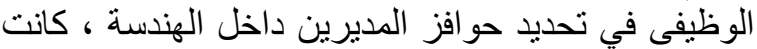

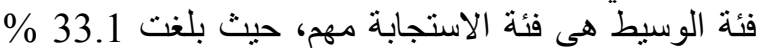
من حجم العينة ككل. كذللك كانت فئة الوسيط لآنة الأراء

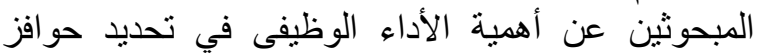

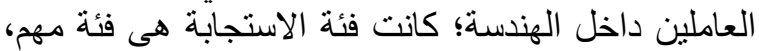
حيث بلغت 53.7 \% من حجم العينة ككل.
المقياس للاستخدام فى أغراض البحث العلمى فى هذا

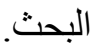
2-2-3 المناخ المنظمى المدرك يقصد بمتغير المناخ المنظمى المدرك المنى فى هذا البحث فئة واسعة من المتغيرات الادراكية التى تعكس التئن التفاعلات

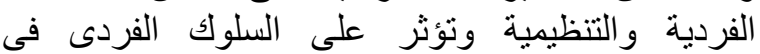

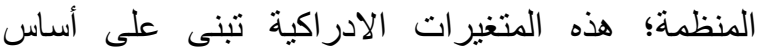
تصورات الفرد لجوانب بيئة العمل خلادل فئل فترة زئل زمنية

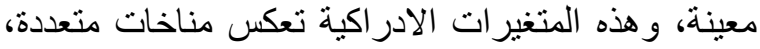

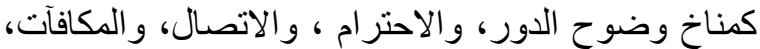

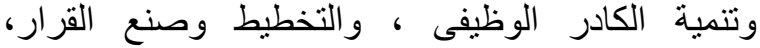

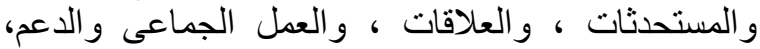

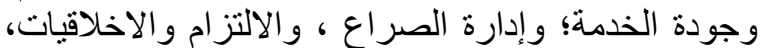

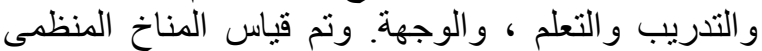
المدرك بمقياس مركب تجميعى مكون من مئة وثمانية بندا ولندا

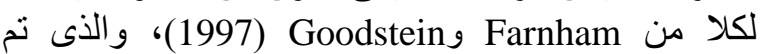
تعريبه من قبل المؤلف مع اجراء بعض التعديلات الطفيفة

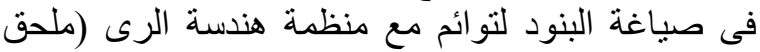

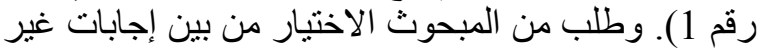

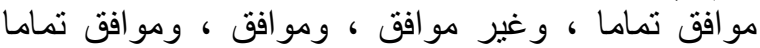

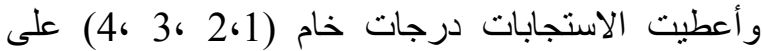

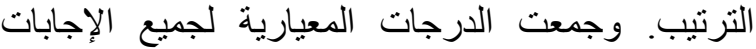
لتعبر عن الدرجة الكلية لمقياس المناخ المنظمى المئي المدرك. وبلغ المتوسط الحسابى للارجة الكلية للمقياس 220.09 درجة، و وانحر اف معيارى قدره 28.32 درجة، ولانة وقد بلغت

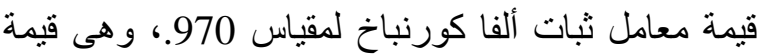

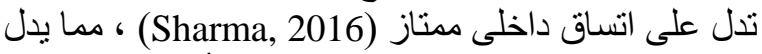
على صلاحية المقياس للاستخدام فى أغراز أغ اضل البحث العلمى فى هذا البحث.

3-2-3 بعض متغيرات عواقب المناخ المنظمى المدرك الئو

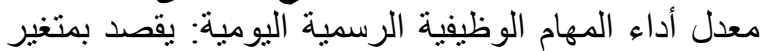
معدل أداء المهام الوظيفية الرسمية اليومية في هذا الرية البحثية

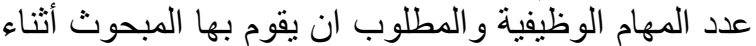

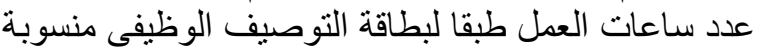
الى عدد ساعات العمل الرسمية اللازمة لأداء هذه اليطا المهام

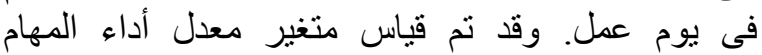

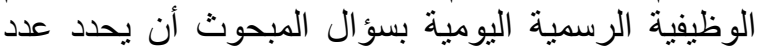

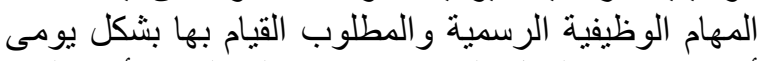

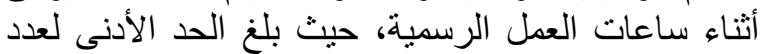

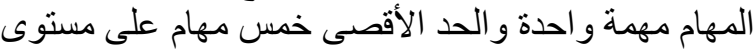

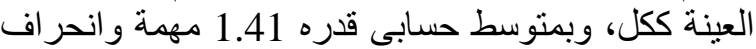

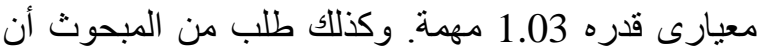

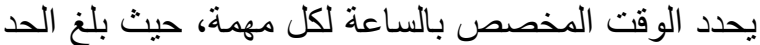

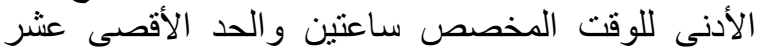

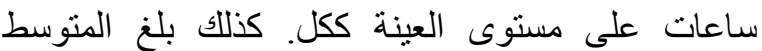
الحسابى للوقت المخصص لألوى لأداء المهام الوظيفية اليومية

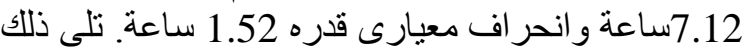
حساب معدل أداء المهام الوظيفية الرسمية اليومية من الئه

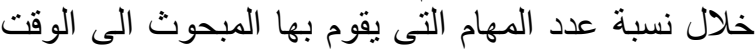
اللازم لأداء هذه المهام. هذا وقد بلغ المتوسط الحسابى الحي 
وباستخدام طريقة إدخال كل المتغير ات معاً لثناث معادلات

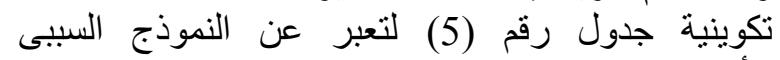
كما تم استبعاد معاملات المسار و التىى تقل قيمتها عن

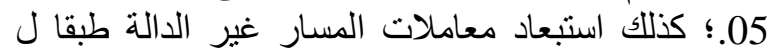

(Kerlinger and Pedhazur, 1973) تلى ذلك إجر اء تحليل الانحدار الخطى المتعدد مرة الحمان

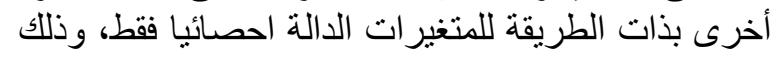

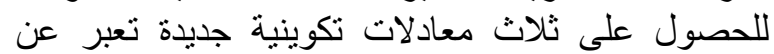

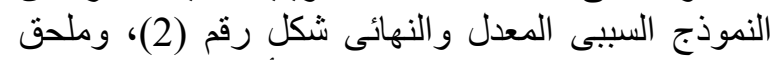

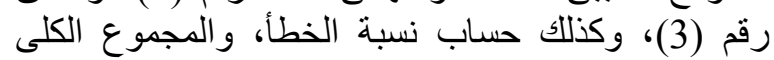

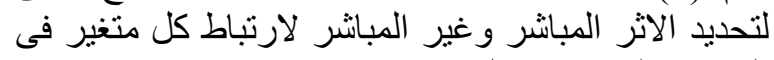

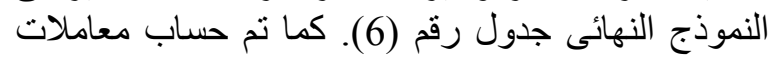

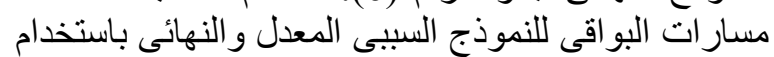
المعادلة والتى أشار اليها كلا من(

$$
\text { (Pedhazur, } 1973 \text { وهى كالتالى: }
$$

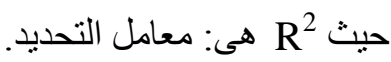

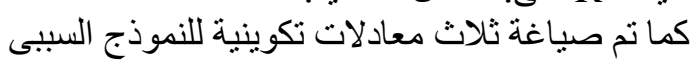

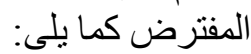

$X_{6}=P_{61} X_{1}+P_{62} X_{2}+P_{63} X_{3}+P_{64} X_{4}+P_{65} X_{5}+e_{6}$ $\mathrm{X}_{7}=\mathrm{P}_{71} \mathrm{X}_{1}+\mathrm{P}_{72} \mathrm{X}_{2}+\mathrm{P}_{73} \mathrm{X}_{3}+\mathrm{P}_{74} \mathrm{X}_{4}+\mathrm{P}_{75} \mathrm{X}_{5}+\mathrm{P}_{76} \mathrm{X}_{6}+\mathrm{e}_{7}$ $\mathrm{X}_{8}=\mathrm{P}_{81} \mathrm{X}_{1}+\mathrm{P}_{82} \mathrm{X}_{2}+\mathrm{P}_{83} \mathrm{X}_{3}+\mathrm{P}_{84} \mathrm{X}_{4}+\mathrm{P}_{85} \mathrm{X}_{5}+\mathrm{P}_{86} \mathrm{X}_{6}+\mathrm{e}_{8}$ حيث: X X $X_{1}=X_{2}=X_{2}$ الحداثة؛ حيو منظمية؛ المنظمى المدرك؛ الرسمية؛ X X

\section{4. - النتائج ومناقشتها \\ 1-4 بعض الخصائص السيكوميترية لمقياس المناخ المنظمى المدرك وابعاده}

لتقدير ثبات وصدئ المدرو الاتساق الداخلى لمقياس المناخ

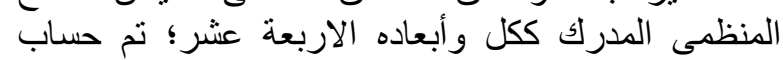

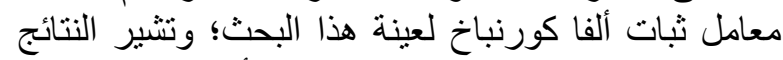

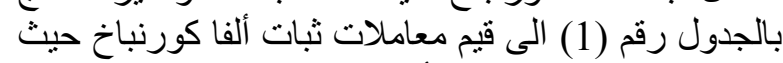

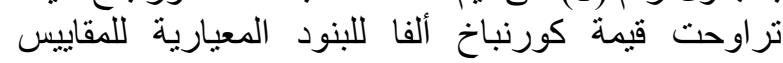

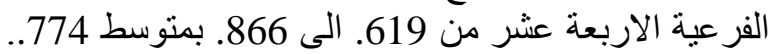

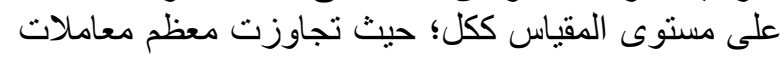

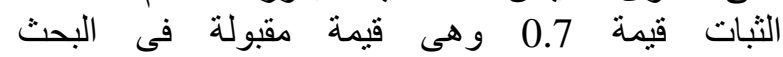

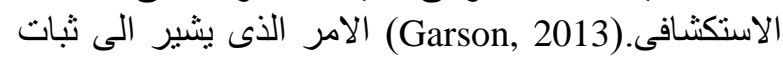

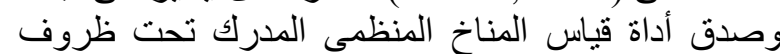

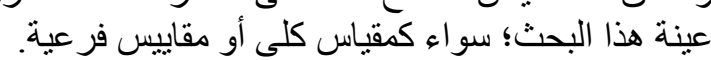

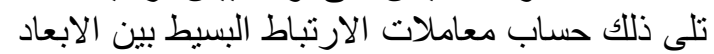

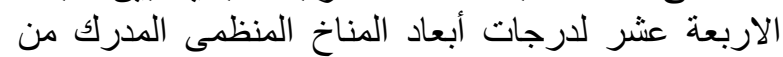

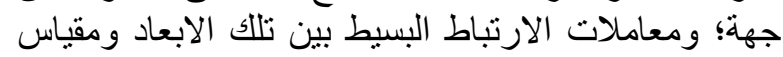

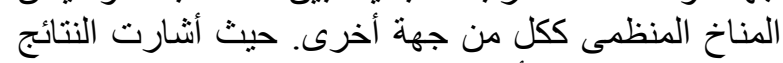

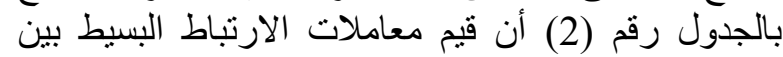

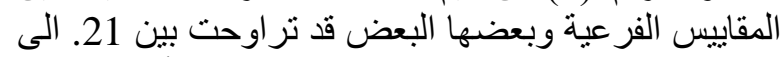
81. و هى علاقات معنوية عند مستوى احتمالى أقل من بن

\section{3-3 الأساليب الإحصائية}

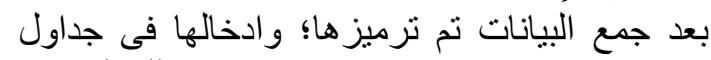

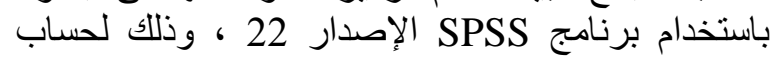

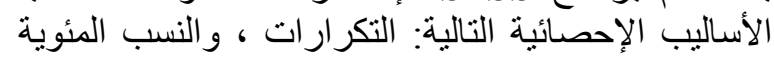

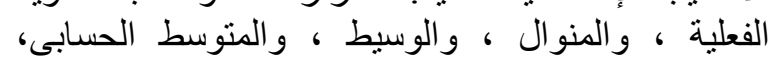
والانحر اف المعيارى، وحساب الدرجات الدات المعيارية طبقا لتوزيع للارجات الخام الخام للمقاييس المركبة التجميعية.

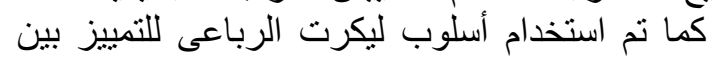

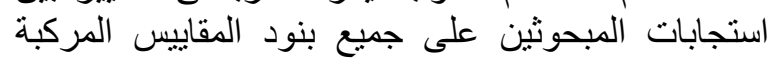

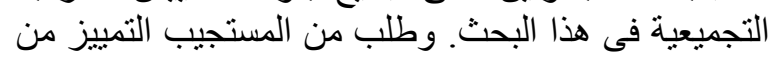

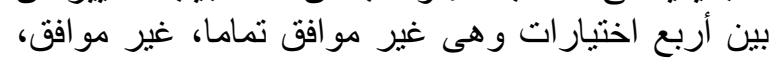

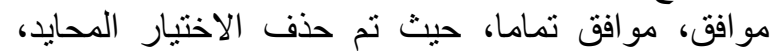

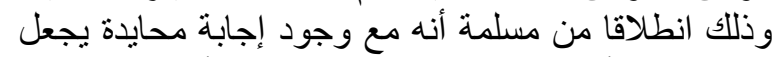

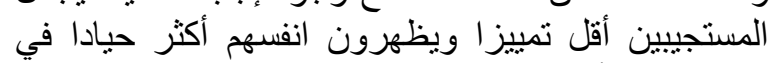

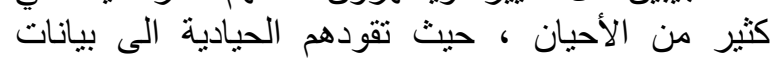

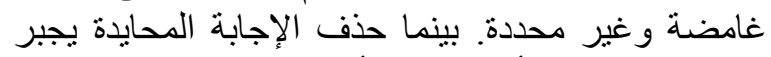

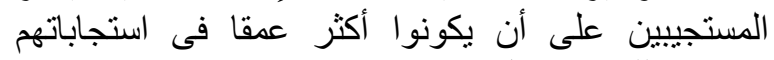

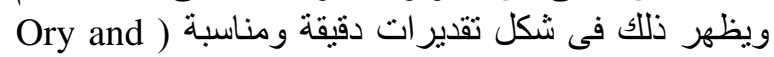
. (Wise, 1981 كذلك قبل تقدير معامل ثبات ألفا كورنباخ تم اجراء

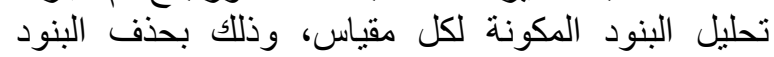

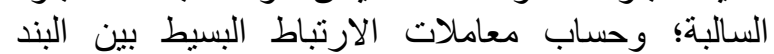

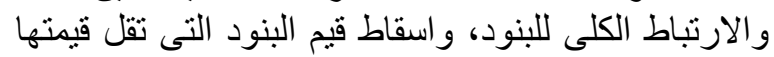

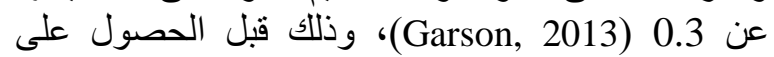
الدرجة الكلية للمقياس المركب التجميعى في هذا البحث.

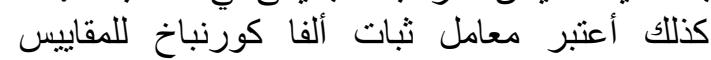

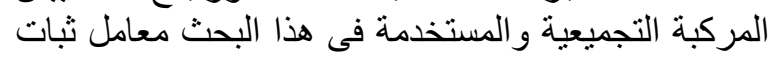

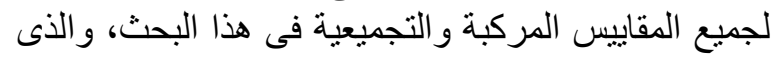

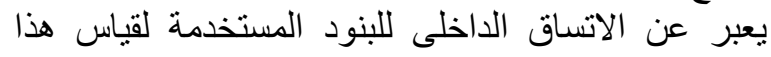

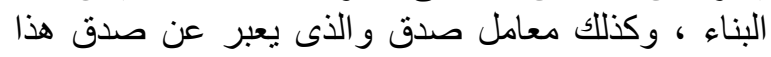

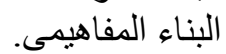
كذللك تم استخدام أسلوب الانحدار الخطى المتعدد Oبريقة المربعات الصغرى العادية Squares Method (OLSM)

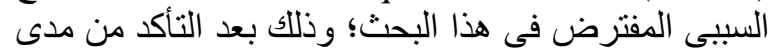

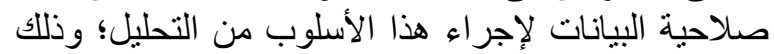

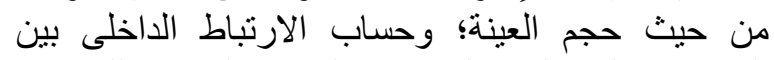

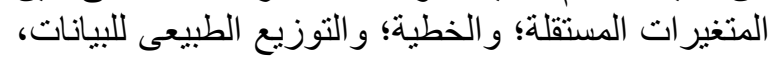

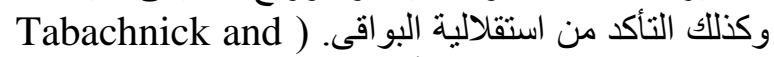

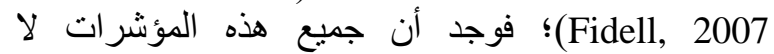

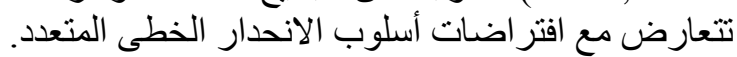

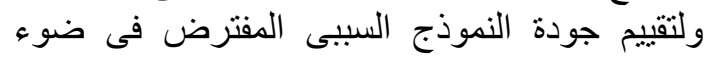

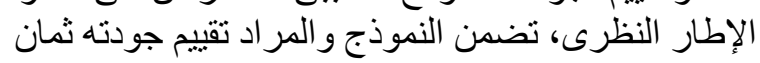

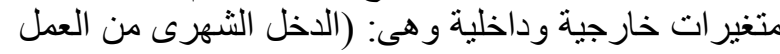

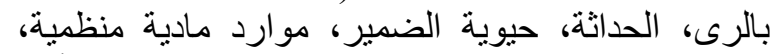

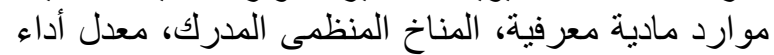

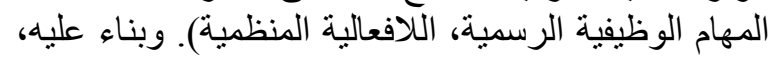

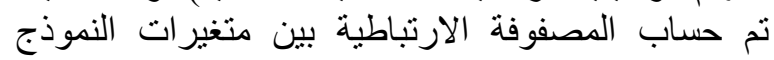

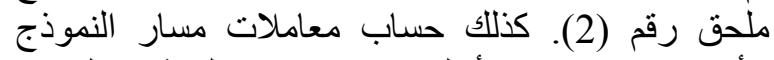
الأساسى باستخدام أسلوب الانحدار الخطى المتعدد 
Perceived organizational climate for a sample of ...................................................

جدول (1): المتوسط والاتحراف المعيارى ومعاملات ثبات الفا كورنباخ للبنود المعيارية لأبعاد المناخ المنظمى والدرجة الكلية لمقياس

\begin{tabular}{|c|c|c|c|c|c|}
\hline للبنود كورنباخ المعيارية ألفا & الاتحريافى & الحستوسي & في المقدياس البنود & عدد البنود فى المقياس & المقياس \\
\hline .970 & 28.32 & 220.09 & 74 & 108 & المناخ المنظمى المدرك \\
\hline .780 & 3.51 & 22.95 & 8 & 9 & وضوح الدور \\
\hline .858 & 2.84 & 20.27 & 6 & 6 & الاحتر ام \\
\hline .853 & 4.79 & 30.35 & 10 & 12 & الاتصالات \\
\hline .697 & 2.00 & 6.17 & 3 & 10 & نسق المكافآت \\
\hline .808 & 3.97 & 22.19 & 8 & 10 & تنمية الكادر الوظيفى \\
\hline .807 & 4.04 & 21.48 & 8 & 11 & التخطيط وصنع القرار \\
\hline .828 & 2.96 & 13.94 & 5 & 5 & المستحدثات \\
\hline .754 & 2.47 & 13.80 & 5 & 5 & العلاقات \\
\hline .619 & 1.84 & 7.76 & 3 & 9 & العمل الجماعى و الدعم \\
\hline .783 & 2.08 & 12.71 & 4 & 4 & جودة الخدمة \\
\hline .678 & 2.06 & 11.41 & 4 & 5 & إدارة الصر اع \\
\hline .866 & 4.28 & 27.15 & 9 & 9 & الالتز ام و الاخلاقيات \\
\hline .842 & 3.51 & 20.28 & 7 & 7 & التندريب و التعلم \\
\hline .667 & 1.87 & 11.54 & 4 & 6 & الوجهة \\
\hline
\end{tabular}

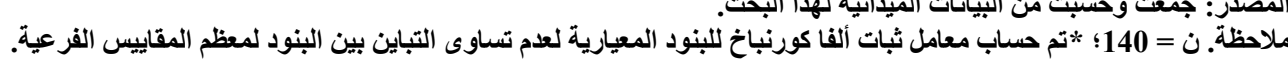

\begin{tabular}{|c|c|c|c|c|c|c|c|c|c|c|c|c|c|c|c|c|}
\hline \multirow[b]{2}{*}{15} & \multicolumn{11}{|c|}{ كى المدرك وأبعاده. } & \multicolumn{5}{|c|}{ جدول (2):معاملات الارتباط البسيط بين المناخ المنظم } \\
\hline & 14 & 13 & 12 & 11 & 10 & 9 & 8 & 7 & 6 & 5 & 4 & 3 & 2 & 1 & المناخ المنظمي المدرك وابعاده & \\
\hline & & & & & & & & & & & & & & 1. & المناخ المنظمى المدرك & 1 \\
\hline & & & & & & & & & & & & & 1. & $.58 * *$ & وضوح الدور & 2 \\
\hline & & & & & & & & & & & & 1. & $.56 * *$ & $.73^{* *}$ & الاحترام & 3 \\
\hline & & & & & & & & & & & 1. & $.75 * *$ & $.63 * *$ & $.86 * *$ & الاتصالات & 4 \\
\hline & & & & & & & & & & 1. & .02 & -.03 & .13 & .18 & المكافآت & 5 \\
\hline & & & & & & & & & 1. & $.28 * *$ & $.66 * *$ & $.46^{* *}$ & $.45 * *$ & $.83^{* *}$ & تنمية الكادر الوظيفى & 6 \\
\hline & & & & & & & & 1. & $.68 * *$ & $.42 * *$ & $.52 * *$ & $.43^{* *}$ & $.41 * *$ & $.82 * *$ & التخطيط وصنع القرار & 7 \\
\hline & & & & & & & 1. & $.63 * *$ & $.70 * *$ & $.29 * *$ & $.69 * *$ & $.43^{* *}$ & $.44 * *$ & $.84 * *$ & المستحدثات & 8 \\
\hline & & & & & & 1. & $.61 * *$ & $.74 * *$ & $.59 * *$ & $.30 * *$ & $.54 * *$ & $.41^{* *}$ & $.21 *$ & $.68^{* *}$ & العلاقات & 9 \\
\hline & & & & & 1. & $.24 * *$ & .08 & $.20 *$ & .16 & .06 & -.03 & -.08 & .11 & .09 & العمل الجماعى والدعم & 10 \\
\hline & & & & 1. & $-.05-$ & $.40 * *$ & $.55^{* *}$ & $.50 * *$ & $.44 * *$ & .12 & $.51 * *$ & $.53 * *$ & $.44 * *$ & $.69 * *$ & جودة الخدمة & 11 \\
\hline & & & 1. & $.49 * *$ & $-.06-$ & $.43^{* *}$ & $.38 * *$ & $.47 * *$ & $.35 * *$ & $.28 * *$ & $.46 * *$ & $.41^{* *}$ & $.39 * *$ & $.54 * *$ & ادارة الصراع & 12 \\
\hline & & 1. & $.61 * *$ & $.70 * *$ & $.24 * *$ & $.70 * *$ & $.68 * *$ & $.81 * *$ & $.61 * *$ & $.29 * *$ & $.60 * *$ & $.56^{* * *}$ & $.47 * *$ & $.89 * *$ & الالتز ام والاخلاقيات & 13 \\
\hline & 1. & $.69 * *$ & $.47 * *$ & $.53 * *$ & $.26 * *$ & $.49 * *$ & $.62 * *$ & $.64 * *$ & $.70 * *$ & $.28 * *$. & $.55 * *$ & $.39 * *$ & $.35 * *$ & $.78 * *$ & التدريب والتعلم & 14 \\
\hline 1. & $.62 * *$ & $.69 * *$ & $.30 * *$ & $.45 * *$ & $.39 * *$ & $.57 * *$ & $.51 * *$ & $.67 * *$ & $.56 * *$ & $.33 * *$. & $.44 * *$ & $.41^{* *}$ & $.35 * *$ & $.69 * *$ & الوجهه & 15 \\
\hline
\end{tabular}

ذى جوهر مشترك ، الا ان الابعاد الاربعة عشر متمبزة الإنيز

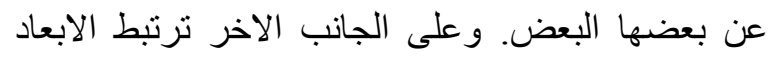

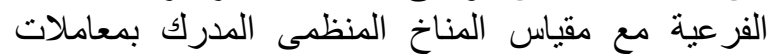

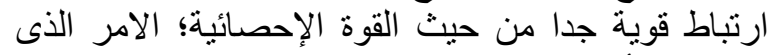

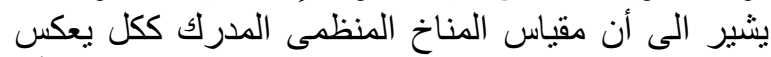

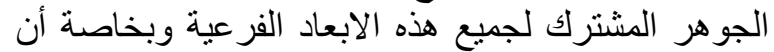

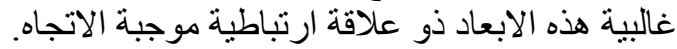

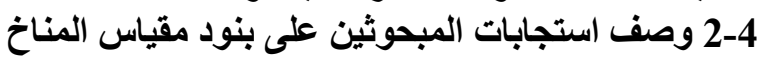
المنظمى المدرك تبعا لفئات الاستجابية.

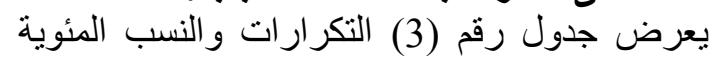
الصحيحة لاستجابات المبحوثين على كل بند الند من بنود

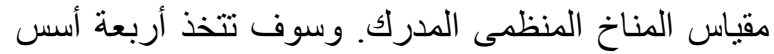

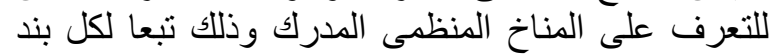

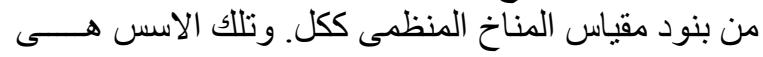

05.، 01.، ومعظمها متوسط الى قوى جدا من حيث قوة

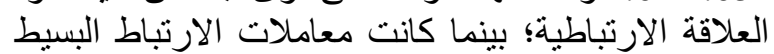

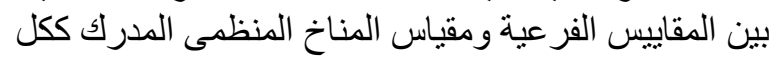

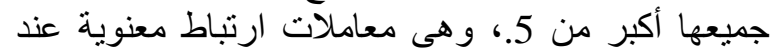
مستوى احتمالى أقل من 01.، وقوية جدا من حن حيث قوة

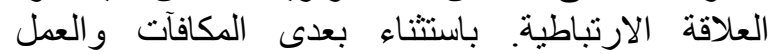

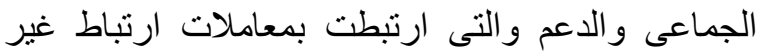
معنوية وطفيفة سواء بين باقى المقاييس الفرعية من جهة؛

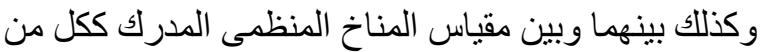
جهة أخرى؛ وذلك طبقا لتفسير قوة العلاقة الارتباطية ل

(Cohen, 2013)

النتائج السابقة تشير الى أن القوة الإحصائية للعلاقات

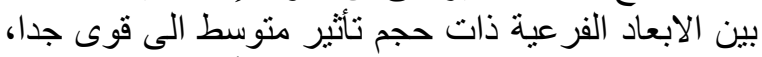

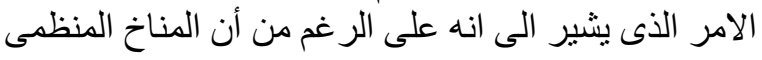


وبالنظر الى استجابات المبحوثين على مستوى

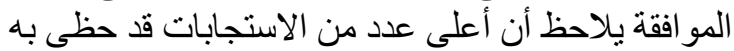

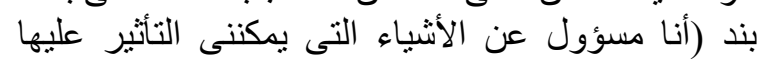

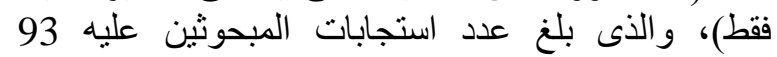

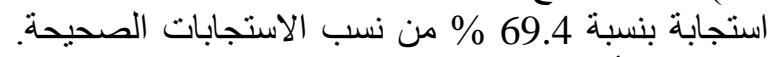

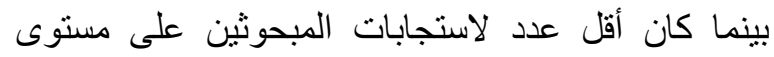
المو افقة والذى بلغ 50 إجابة وبنسبة 36.8 \% 36.

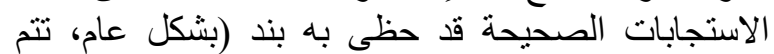

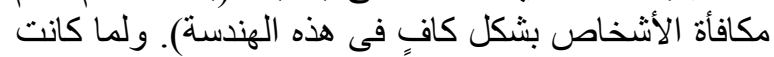

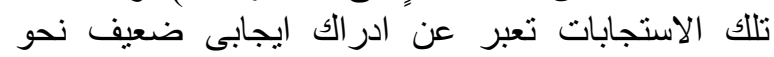

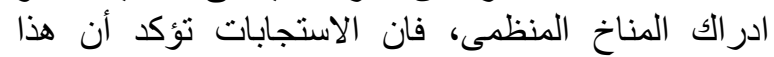

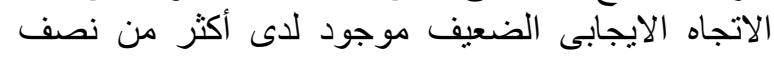
المبحوثين مع استثناءات قليلة.

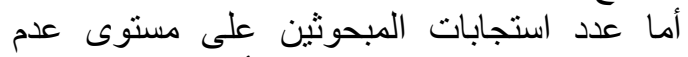
المو افقة فلم يزد عن 46 استجابة على المئى أى من بنود المناخ المناخ

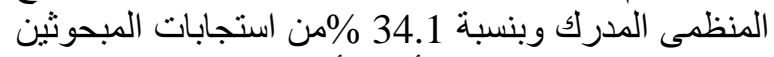

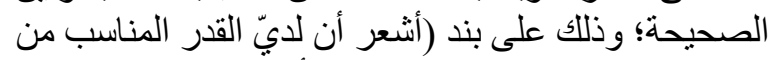

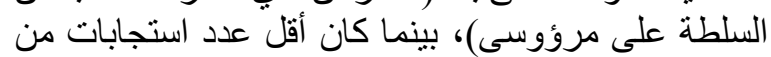

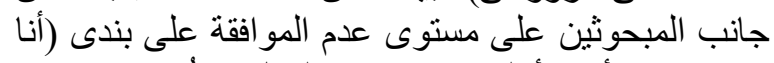

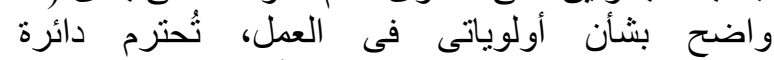

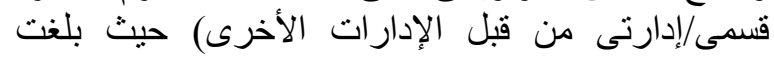

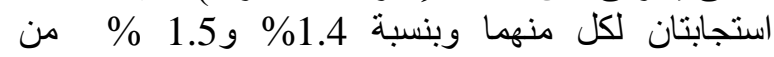
استجابات المبحوثين الصحيحة على على الترتيب. ولما كانت

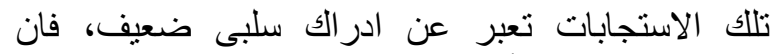

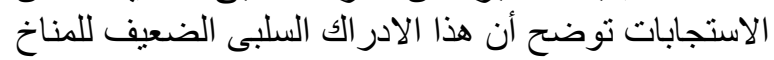

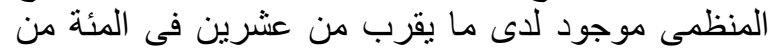
المبحوثين فى معظم البنود.

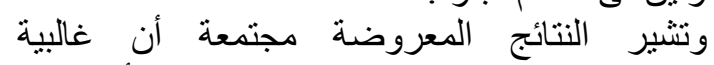

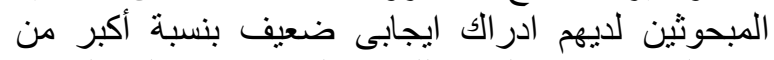

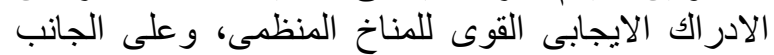

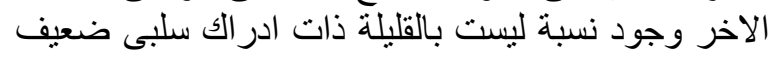

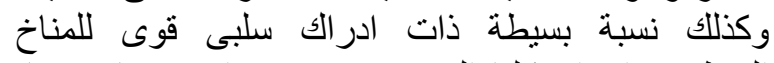

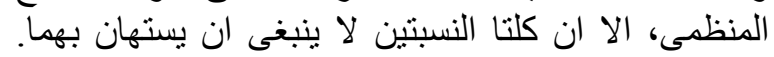

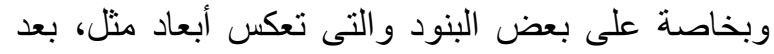

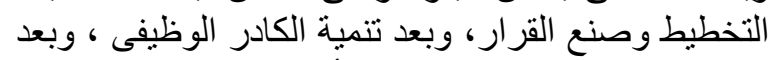

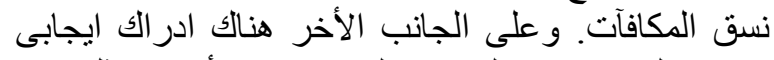

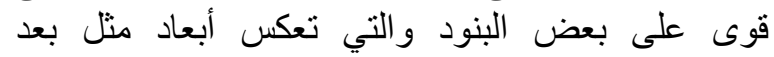

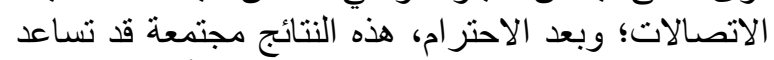

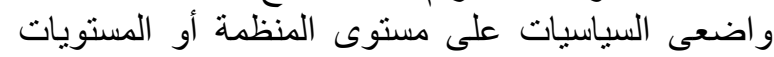

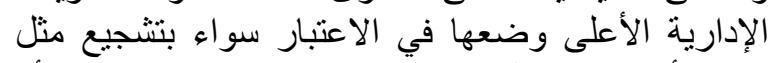

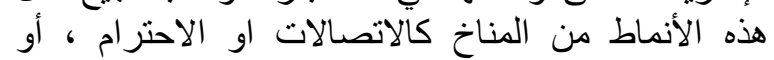

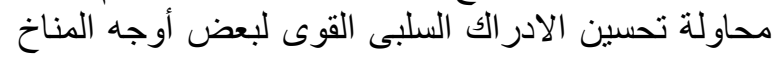

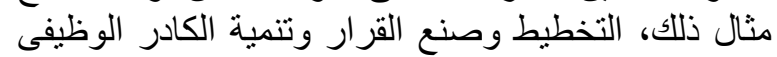

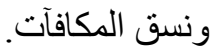

الاستجابات الاربع المستخدمة فى الحصول على البيانات

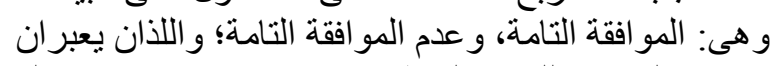

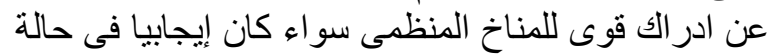

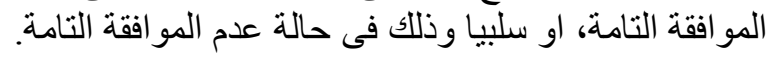

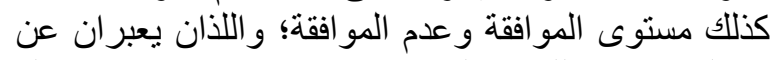

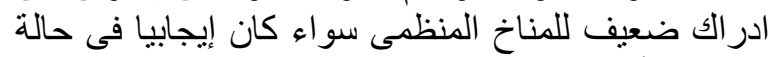
المو اققة، أو سلبيا وذلك في حالة عدم المو الفقة.

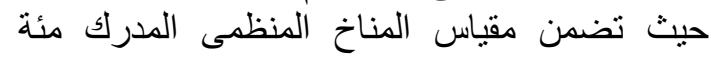

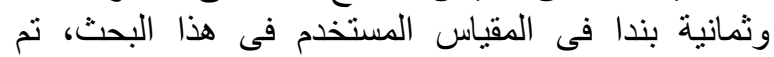

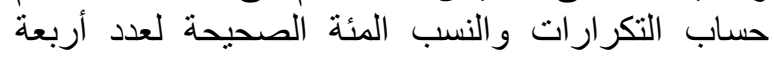

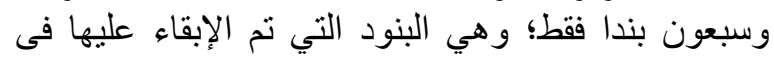

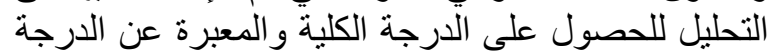
الكلية للمناخ المنظمى المدرك.

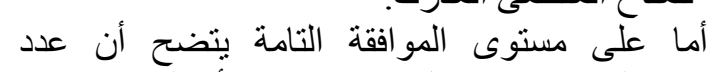

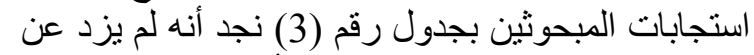

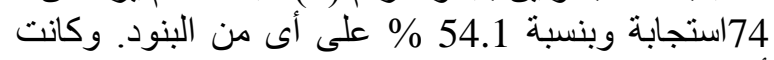

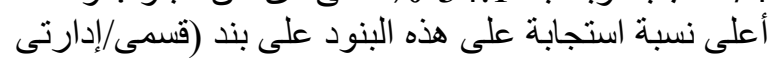

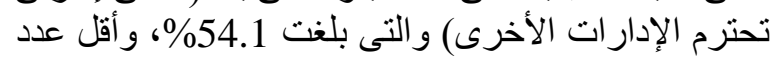

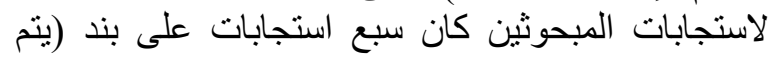

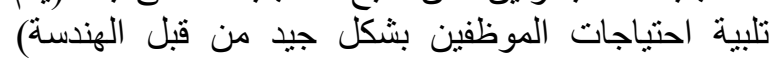

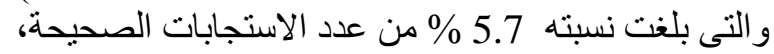

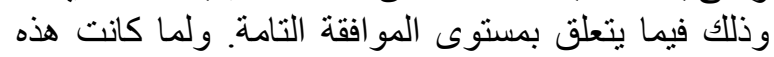

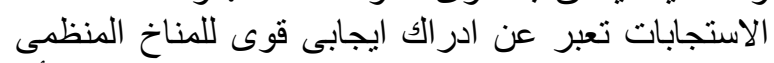

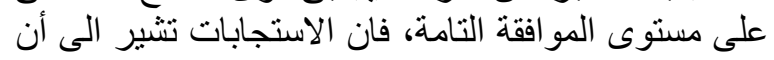

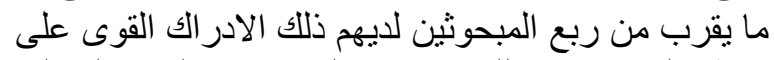

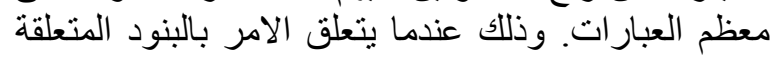

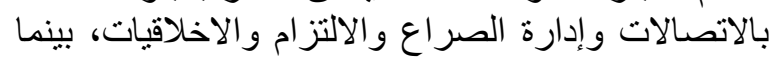

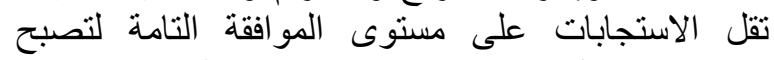

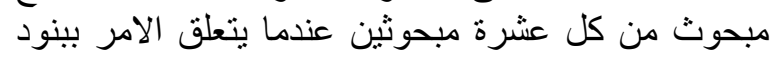
بعدى التدريب و التعلم و الوجهة، وتئن وتزداد نسبة الاستجابات

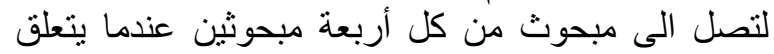
الامر ببنود بعدى وضود من الدول الدور والاحتر ام.

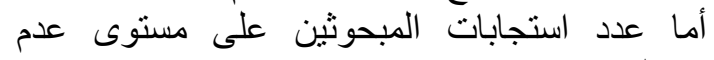
المو افقة التامة قد تراوح بين 23 استجابة بنسبة 16.8 \%

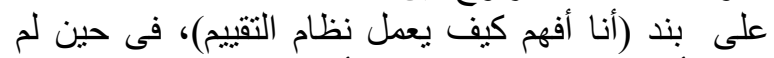

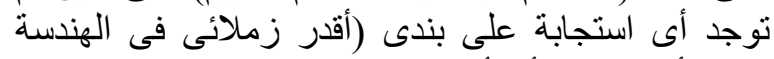

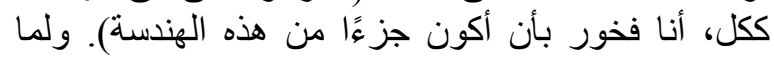

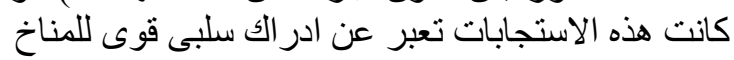

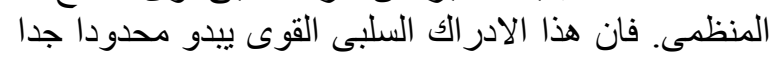

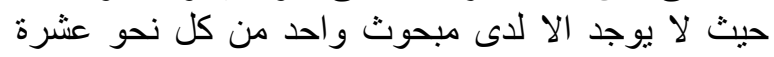

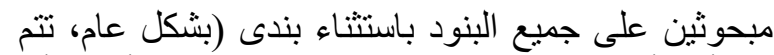

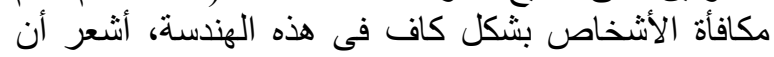
لايّ القدر المناسب من السلطة على مرؤوسى). 
جدول(3): التكرارات والنسب المئوية الصحيحة لاستجابات المبحوثين على بنود مقياس المناخ المنظمى المدرك ككل والمستخدمة فى التحليل النهائى تبعا لفئات الاستجابة.

\begin{tabular}{|c|c|c|c|c|c|c|c|c|}
\hline \multicolumn{2}{|c|}{ موافق تماما } & \multicolumn{2}{|c|}{ 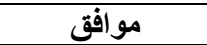 } & \multicolumn{2}{|c|}{ غير موافق } & \multicolumn{2}{|c|}{ غير موافق تماما } & \multirow[b]{2}{*}{ البند } \\
\hline$\%$ & 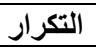 & $\%$ & 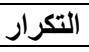 & $\%$ & 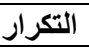 & $\%$ & 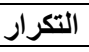 & \\
\hline & & & & & & & & بعد وضوح الدور \\
\hline 33.1 & 46 & 64.0 & 89 & 1.4 & 2 & 1.4 & 2 & أناو اضح بشأن أولو ياتى فى العمل. \\
\hline 39.1 & 54 & 55.1 & 76 & 3.6 & 5 & 2.2 & 3 & أنا أعرف ما هى مسؤولياتى. \\
\hline 21.2 & 28 & 59.8 & 79 & 14.4 & 19 & 4.5 & 6 & تجارب زملائى. العنة يستفيد بشكل أفضل من \\
\hline 27.3 & 36 & 49.2 & 65 & 20.5 & 27 & 3.0 & 4 & الهندسة لديها موظفين ذات نو عية جيدة. \\
\hline & & & & & & & & بعد الاحترام \\
\hline 29.9 & 41 & 62.8 & 86 & 5.8 & 8 & 1.5 & 2 & أشعر بالتقدير من قبل زملائى فى الهندسة. \\
\hline 36.3 & 49 & 60.0 & 81 & 3.0 & 4 & .7 & 1 & أقدر زملائي في الهندسة. \\
\hline 47.4 & 64 & 44.4 & 60 & 5.9 & 8 & 2.2 & 3 & أشعر بالتقدير من قبل زملائى فى الهندسة. \\
\hline 41.2 & 56 & 52.2 & 71 & 6.6 & 9 & - & - & أقدر زملائى فى الهندسة ككل. \\
\hline 54.4 & 74 & 39.0 & 53 & 5.9 & 8 & .7 & 1 & قنمى/إدارتى تحترم الإدارات الأخرى. \\
\hline 51.1 & 69 & 46.7 & 63 & 1.5 & 2 & .7 & 1 & الاخترى دائرة قسمى/إدارتى من قبل الإدارات \\
\hline & & & & & & & & بعد الاتصالات \\
\hline 29.7 & 41 & 58.0 & 80 & 10.9 & 15 & 1.4 & 2 & أتلقى جميع المعلومات التي أحتاجها للقيام بعملي. \\
\hline 46.7 & 63 & 42.2 & 57 & 6.7 & 9 & 4.4 & 6 & الأخرى. إدارتى تعمل بشكل جيد مع الإدارات \\
\hline 38.5 & 52 & 50.4 & 68 & 8.9 & 12 & 2.2 & 3 & 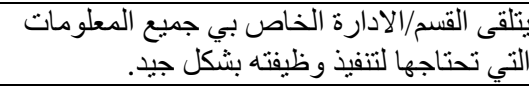 \\
\hline 29.6 & 40 & 57.8 & 78 & 7.4 & 10 & 5.2 & 7 & 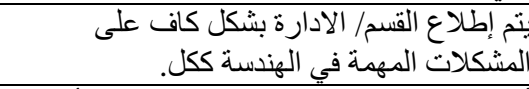 \\
\hline 23.7 & 32 & 65.2 & 88 & 8.9 & 12 & 2.2 & 3 & ألعامة بوضنوح كيف يمكنتي المساهمة في الأهداف \\
\hline 21.0 & 29 & 53.6 & 74 & 21.7 & 30 & 3.6 & 5 & الادارة الخاص كافية للتعبير عن آرائي في القسم/ \\
\hline 25.0 & 34 & 61.8 & 84 & 11.0 & 15 & 2.2 & 3 & بحب زملائي مناقتشة مسائل العمل معي. \\
\hline 24.5 & 34 & 56.8 & 79 & 14.4 & 20 & 4.3 & 6 & بشكل عام، التو اصل فعال في هذه الهندسة. \\
\hline 23.0 & 32 & 59.7 & 83 & 13.7 & 19 & 3.6 & 5 & 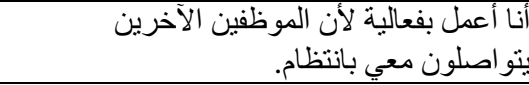 \\
\hline & & & & & & & & بعد نسق المكافآت \\
\hline 15.9 & 22 & 47.1 & 65 & 27.5 & 38 & 9.4 & 13 & معله بشكل مناسب. لا يمثل أهمية قصوى يتم التعامل \\
\hline 16.2 & 22 & 36.8 & 50 & 30.9 & 42 & 16.2 & 22 & هذه الهندسة، عام، مكافأة الأشخاص بشكل كافٍ في \\
\hline & & & & & & & & بعد تنمية الكادر الوظيفى ب \\
\hline 14.0 & 19 & 55.9 & 76 & 25.0 & 34 & 5.1 & 7 & في الاعتبار. مراجعة عملى بانتظام مع وضع تطور عملى \\
\hline 8.8 & 12 & 40.9 & 56 & 33.6 & 46 & 16.8 & 23 & أنا أفهم كيف يعمل نظام التقييم. \\
\hline 9.6 & 13 & 61.8 & 84 & 20.6 & 28 & 8.1 & 11 & هناك وسيلة كافية لتقييم أدائي. \\
\hline 14.3 & 19 & 60.9 & 81 & 19.5 & 26 & 5.3 & 7 & بمكني تطوير مسبرتي داخل الهندسة. \\
\hline 19.7 & 26 & 47.0 & 62 & 25.0 & 33 & 8.3 & 11 & الدشيّ فرصة لرؤية تقرير تقييمي ومناقثته مع \\
\hline 15.4 & 21 & 59.6 & 81 & 19.1 & 26 & 5.9 & 8 & في الهندسة. عام، هناك نظام مناسب للتطوير الوظيفي \\
\hline 16.5 & 22 & 55.6 & 74 & 21.8 & 29 & 6.0 & 8 & وظيفتي الحالية تستفيد بالكامل من مو اهبي. \\
\hline 14.9 & 20 & 65.7 & 88 & 15.7 & 21 & 3.7 & 5 & الؤخذة التنمية المهنية على محمل الجد في \\
\hline & & & & & & & & بعد التخطيط وصنع القرار \\
\hline 8.3 & 11 & 58.3 & 77 & 25.8 & 34 & 7.6 & 10 & الهندسة. عام؛ يتم تنفيذ النخطيط بشكل مناسب في \\
\hline 9.6 & 13 & 50.4 & 68 & 32.6 & 44 & 7.4 & 10 & 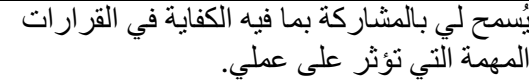 \\
\hline
\end{tabular}




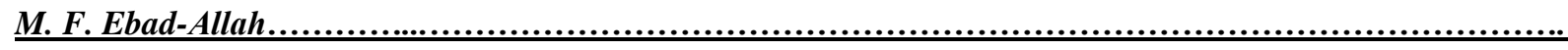

\begin{tabular}{|c|c|c|c|c|c|c|c|c|}
\hline \multicolumn{2}{|c|}{ موافق تماما } & \multicolumn{2}{|c|}{ موافق } & \multicolumn{2}{|c|}{ غير موافق } & \multicolumn{2}{|c|}{ غير موافق تماما } & \multirow[b]{2}{*}{ البند } \\
\hline$\%$ & التكرار & $\%$ & التكرار & $\%$ & التكرار & $\%$ & التكرار & \\
\hline 11.8 & 16 & 67.6 & 92 & 14.7 & 20 & 5.9 & 8 & أنا مفوض بالعمل و السلطة المناسبة لخبرتي. \\
\hline 12.7 & 17 & 69.4 & 93 & 14.9 & 20 & 3.0 & 4 & فقطا مسؤول عن الأشياء التي يمكنني التأثيّر عليها \\
\hline 14.7 & 20 & 63.2 & 86 & 16.2 & 22 & 5.9 & 8 & يشاركنى المشرف الاستشارة قبل اتخاذ إجر اء. \\
\hline 14.0 & 19 & 52.9 & 72 & 25.0 & 34 & 8.1 & 11 & الدهمة في في العندسة. التي يتم بها اتخاذ القرارات \\
\hline 10.4 & 14 & 51.1 & 69 & 27.4 & 37 & 11.1 & 15 & بشكل جيد. إطلاع جيد بما يكفي لاتخاذ القرارات \\
\hline 11.9 & 16 & 38.5 & 52 & 34.1 & 46 & 15.6 & 21 & أَثشعر أن لايّ القدر المناسب من السلطة على \\
\hline 5.9 & 8 & 65.4 & 89 & 20.6 & 28 & 8.1 & 11 & 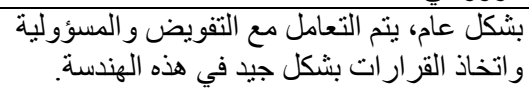 \\
\hline & & & & & & & & بعد المستحدثات \\
\hline 13.3 & 18 & 60.7 & 82 & 18.5 & 25 & 7.4 & 10 & عملى يشجعني أن أكون مبتكرًا. \\
\hline 18.7 & 25 & 53.7 & 72 & 17.9 & 24 & 9.7 & 13 & يتم تتجيع هندستى على الابتكار. \\
\hline 13.3 & 18 & 57.8 & 78 & 20.7 & 28 & 8.1 & 11 & تخطط الهندسة بشكل كاف للمستقبل. \\
\hline 14.0 & 19 & 61.0 & 83 & 17.6 & 24 & 7.4 & 10 & تستجيب الهندسة على الفور للتكنولوجيا الجديدة. \\
\hline 5.8 & 8 & 67.2 & 92 & 18.2 & 25 & 8.8 & 12 & التشروط الجديدة. أساليب العمل هنا بسر عة لتلبية \\
\hline & & & & & & & & بعد العلاقات \\
\hline 5.2 & 7 & 57.8 & 78 & 31.1 & 42 & 5.9 & 8 & التينم تلبية احتياجات الموظفين بشكل جيد من قبل \\
\hline 12.0 & 16 & 54.1 & 72 & 25.6 & 34 & 8.3 & 11 & يتم احتر ام احتياجات المر أة بشكل كبير. \\
\hline 11.7 & 16 & 68.6 & 94 & 13.1 & 18 & 6.6 & 9 & الهندسة مرنة من أجل تلبية احتياجات الناس. \\
\hline 15.6 & 21 & 61.5 & 83 & 18.5 & 25 & 4.4 & 6 & 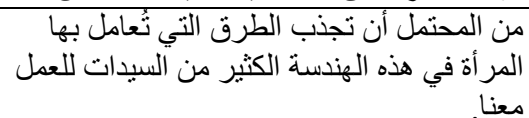 \\
\hline & & & & & & & & بعد العمل الجماعى و الاعم ب \\
\hline 16.9 & 23 & 54.4 & 74 & 19.1 & 26 & 9.6 & 13 & الناس هنا عموما يدعم بعضهم البعض بشكل \\
\hline 26.7 & 36 & 57.0 & 77 & 14.1 & 19 & 2.2 & 3 & وبيسودها رو، حالتعاونة تهتم برعاية الاشخاص \\
\hline & & & & & & & & جودة الخدمة \\
\hline 35.6 & 48 & 53.3 & 72 & 9.6 & 13 & 1.5 & 2 & قصارى جهان الأمر بتقديم خذماتنا، فإننا نبذل \\
\hline 32.3 & 43 & 56.4 & 75 & 9.0 & 12 & 2.3 & 3 & للحو اطن. فخورون بجودة الخدمة التي تقدمها الهندسة \\
\hline 32.1 & 43 & 58.2 & 78 & 8.2 & 11 & 1.5 & 2 & نحن فخورون بجودة الخدمة في هندستتا. \\
\hline 25.4 & 34 & 58.2 & 78 & 15.7 & 21 & .7 & 1 & أماكن أخرى لديها معايير جودة أعلى من مثيلاتها في \\
\hline & & & & & & & & ادارة الصراع \\
\hline 24.6 & 33 & 56.7 & 76 & 17.2 & 23 & 1.5 & 2 & الهندسة. النزاعات بشكل بناء / إيجابي في هذه \\
\hline 20.1 & 27 & 61.9 & 83 & 14.2 & 19 & 3.7 & 5 & تركها تتفاقم. على حل صر اعاتنا بسر عة بدلاً من \\
\hline & & & & & & & & الالتز وام والاخلاقيات \\
\hline 15.4 & 21 & 64.7 & 88 & 19.1 & 26 & .7 & 1 & يتتم المحافظة على دوا افع الموظفين من قبل \\
\hline 20.7 & 28 & 58.5 & 79 & 16.3 & 22 & 4.4 & 6 & الروح المعنوية عالية في معظم الإدارات. \\
\hline 16.2 & 22 & 61.0 & 83 & 14.0 & 19 & 8.8 & 12 & الروح المعنوية مرتفعة في هندستى. \\
\hline 21.6 & 29 & 56.0 & 75 & 17.2 & 23 & 5.2 & 7 & معنوياتي الثخصية مرتفعة. \\
\hline 20.1 & 27 & 64.2 & 86 & 11.9 & 16 & 3.7 & 5 & التز ام الموظفين مرتفع في هذه الهندسة. \\
\hline 26.1 & 35 & 61.9 & 83 & 9.7 & 13 & 2.2 & 3 & تحل المهنسة الغالبية العظمى من مشاكلها \\
\hline 26.5 & 36 & 64.0 & 87 & 9.6 & 13 & - & - & أنا فخور بأن أكون جزءًا من هذه الهندسة. \\
\hline 23.4 & 32 & 62.8 & 86 & 11.7 & 16 & 2.2 & 3 & أشُعر أنني عضو مهم في الهندسة. \\
\hline
\end{tabular}




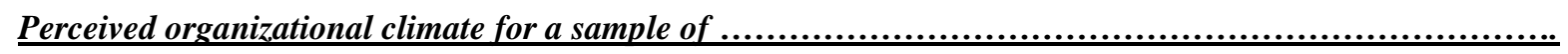

\begin{tabular}{|c|c|c|c|c|c|c|c|c|}
\hline \multicolumn{2}{|c|}{ موافق تماما } & \multicolumn{2}{|c|}{ 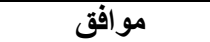 } & \multicolumn{2}{|c|}{ غير موافق } & \multicolumn{2}{|c|}{ غير موافق تماما } & \multirow[b]{2}{*}{ البند } \\
\hline$\%$ & التكرار & $\%$ & التكرار & $\%$ & التكرار & $\%$ & التكرار & \\
\hline 15.6 & 21 & 66.7 & 90 & 14.1 & 19 & 3.7 & 5 & بشكل عام، الناس ملتزمون بشدة فى الهندسة. \\
\hline & & & & & & & & بعد التلاريب والتعلم \\
\hline 13.3 & 18 & 71.1 & 96 & 14.1 & 19 & 1.5 & 2 & معظم الإدارات يتم مر اجعة اعمالها بشكل منتظم. \\
\hline 14.9 & 20 & 66.4 & 89 & 13.4 & 18 & 5.2 & 7 & هناك إجر اءات توجيه مناسبة في هذه الهندسة. \\
\hline 14.8 & 20 & 66.7 & 90 & 14.8 & 20 & 3.7 & 5 & لقد تلقيت التندريب الذي أحتاجه للقيام بعمل جيد. \\
\hline 22.6 & 30 & 60.2 & 80 & 11.3 & 15 & 6.0 & 8 & بعضنا البعض في للتهلم من عملنا. ملتمون بمساعدة \\
\hline 14.9 & 20 & 65.7 & 88 & 14.2 & 19 & 5.2 & 7 & من أنشطت عام، تتعلم هذه الهندسة بقدر الإمكان عمليًا \\
\hline 12.5 & 17 & 64.0 & 87 & 18.4 & 25 & 5.1 & 7 & التندريب الذي تلقيته ذو جودة عالية. \\
\hline 9.8 & 13 & 66.2 & 88 & 15.0 & 20 & 9.0 & 12 & مهار اتي. على التدريب الذي أحتاجه لتطوير \\
\hline & & & & & & & & بعد الوجهة \\
\hline 9.2 & 12 & 64.1 & 84 & 23.7 & 31 & 3.1 & 4 & تالم إبلاغ مستقبل. هذه الهندسة جيدًا لجميع \\
\hline 15.8 & 21 & 67.7 & 90 & 13.5 & 18 & 3.0 & 4 & مساعدة هذه الهنانسة الدور الذى تحقيق أهدافها. ألعبه في \\
\hline 12.7 & 17 & 62.7 & 84 & 17.2 & 23 & 7.5 & 10 & الثخدية. المستقبلية للهندسة تنفق مع أهدافى \\
\hline
\end{tabular}

المبحوثين على مستوى العينة ككل. الامر الذى يشير الى مالى

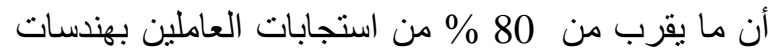

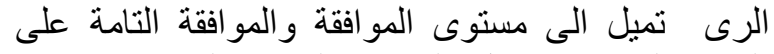

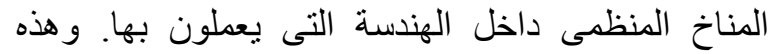

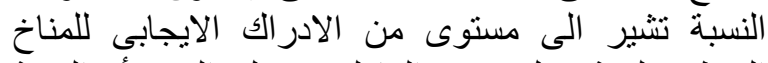

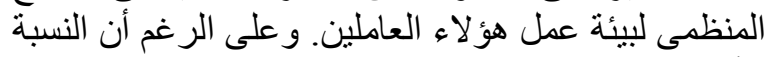

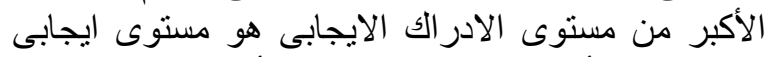

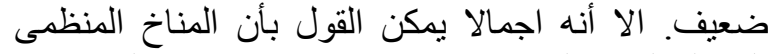

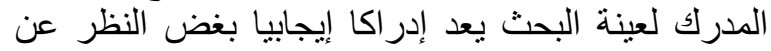

$$
\text { نسبة هذه الادر الك الايجابى. }
$$

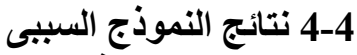
1-4-4 نتائج النموذج السببى الأساسى للنموذج المفترض

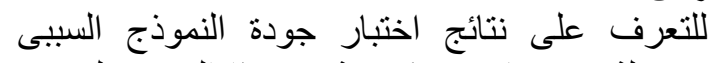

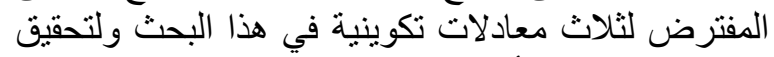

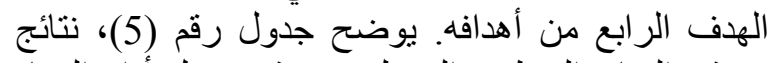

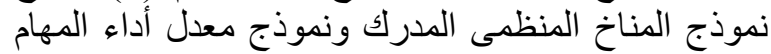
الوظيفية الرسمية ونموذج اللافعالية المنظمية.

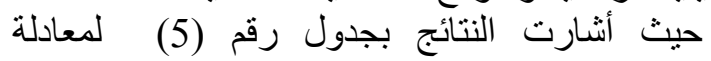

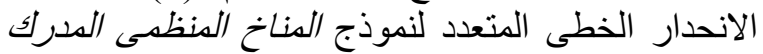

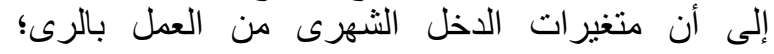

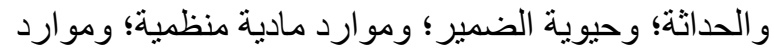

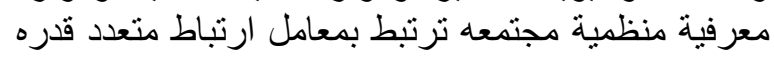

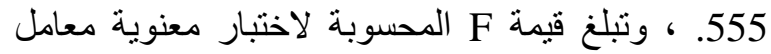

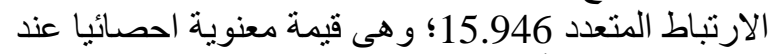

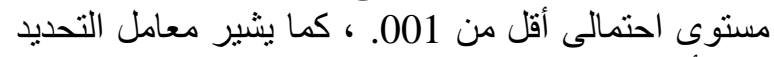

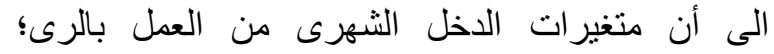

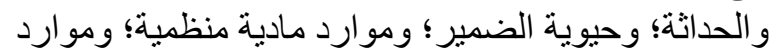

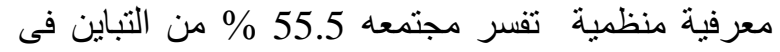

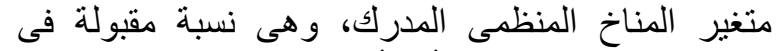
الدراسات الاجتماعية. وتأكد أن متغير وات الدخل الثنهرى
المصدر : جمعت وحصبت من البيانات الميدانية لهذا البحث.

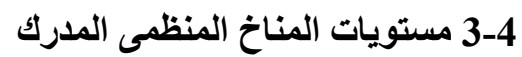
للوقوف على مسنويات المناخ المناخ المناخ المنظمى المدرك على على

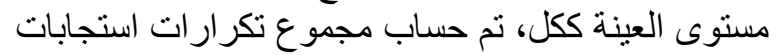
المبحوثين المعبرة عن كل من مستوى عدم العين المو افقة التامة،

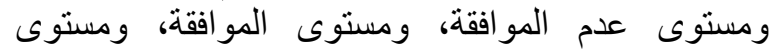
المو افقة التامة. ويعرض جدول رالمولة رقم (4) النتائج المتحصل عليها. حيث يتضح من النتائج أن الاستجابات التى تعبر

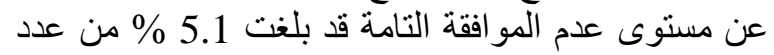
الاستجابات الكلية. بينما بلغت نسبة الاستجابات المعبرة

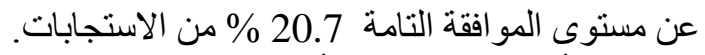

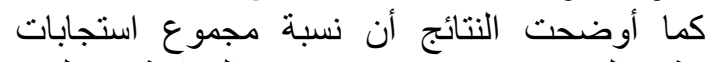
المبحوثين النى تعبر عن مستوى عدم الموافقة قد بلغت النغابت

جدول (4): تجميع التكرارات والنسب المئوية لاستجابات المبحوثين لمستويات المقياس الأربعة لمقياس المباس

\begin{tabular}{|c|c|c|c|}
\hline \multicolumn{4}{|c|}{ المناخ المنظمى المدرك على مستوى العينة ككل } \\
\hline 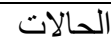 & \multicolumn{2}{|c|}{ الاستجابات } & \multirow[t]{2}{*}{ مستوى الإستجابة } \\
\hline$\%$ & $\%$ & التكرار & \\
\hline 362.1 & 5.1 & 507 & غير موافق تمامـا \\
\hline 1155.7 & 16.2 & 1618 & غير موافق \\
\hline 4141.4 & 58.0 & 5798 & بوافق \\
\hline 1477.9 & 20.7 & 2069 & 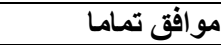 \\
\hline
\end{tabular}

المصدر: جمعت وحسبت من البيانات الميدانية لهاذا البحث.

16.2 \% من إجمالى الاستجابات. وفى المقابل بلغت نسبة استجابات المبحوثين المعبرة عن مستوى الموالئابل الفقة 58.0 \% من إجمالى استجابات العينة ككل. هذا يعنى أن استجابات المبحوثين على مستوى العينة ككل كان منها نسبة 21.3 \%

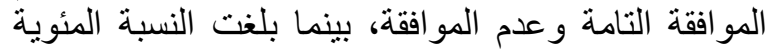

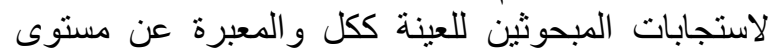

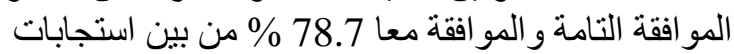




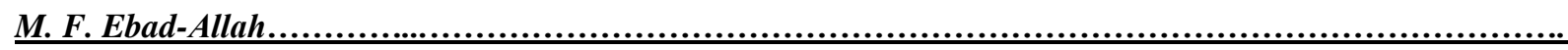

جدول(5): نتائج التحليل المسارى الاساسى لنموذج المناخ المنظمى المدرك ونموذج معدل أداء المهام الوظيفية الرسمية ونموذج

النلافعالية المنظمية.

\begin{tabular}{|c|c|c|c|c|c|c|c|}
\hline \multicolumn{2}{|c|}{ اللافعالية المنظمية } & \multicolumn{2}{|c|}{ معلد أداء المهامة } & \multicolumn{2}{|c|}{ نموذج المداخ المنظمى } & \multirow[t]{2}{*}{ المتفير المستقل } & \multirow[t]{2}{*}{ م } \\
\hline$(\beta)$ & $(\mathrm{r})$ & ( $\beta)$ & $(\mathrm{r})$ & $(\beta)$ & $(\mathrm{r})$ & & \\
\hline-.070 & .146 & .038 & .152 & -.161 & -.262 & الدخل الثهرى من العمل بالرى & 1 \\
\hline-.182 & -.398 & -.012 & -.055 & $.314 * *$ & .339 & الحداثة & 2 \\
\hline .102 & -.221 & $.290^{*}$ & .141 & $.253 * *$ & .356 & حيوية الضمير & 3 \\
\hline $.264 *$ & -.266 & -.211 & -.478 & $.307 *$ & .548 & مو ارد مادية منظمية & 4 \\
\hline-.130 & -.296 & -.094 & -.428 & $.305^{*}$ & .486 & مو ارد معرفية منظمية & 5 \\
\hline$-.812 * * *$ & -.737 & $-.380 *$ & -.452 & & & المناخ المنظمى المدرك & 6 \\
\hline $16.199 * * *$ & - & 4.219* & - & $15.946 * * *$ & - & $\mathbf{F}$ & \\
\hline .607 & - & .360 & - & .555 & - & معامل التحديد R & \\
\hline .626 & - & .800 & - & .667 & - & معامل مسار البواقى & \\
\hline
\end{tabular}

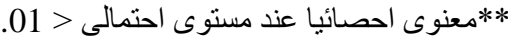

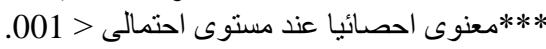

أداء المهام الوظيفية الرسمية، وهى نسبة بسيطة فى الإئي

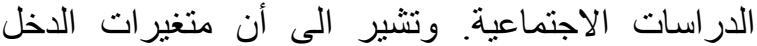

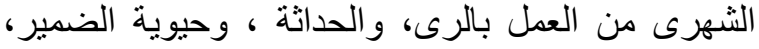

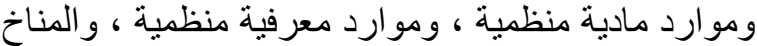

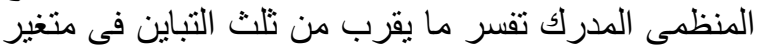

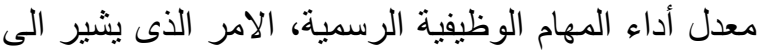

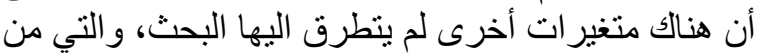

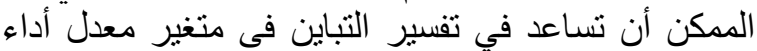
المهام الوظيفية الرسمية. كما يتضح من النتائج أن كلا من متغيرى الرسية حيوية

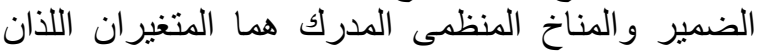

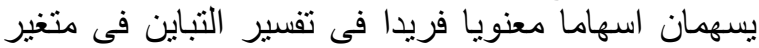

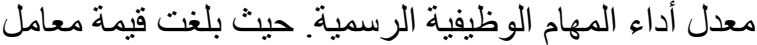
بيتا المعيارية 290.، 380.، على الترتيب، ولئ وهما قيمتان

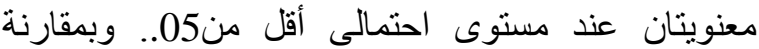
معامل بيتا المعيارى بمعامل الارتباط البسيط لهنيط لهذين

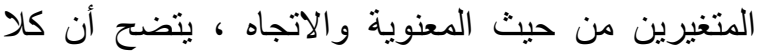

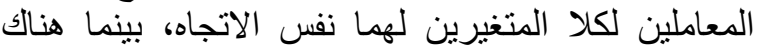

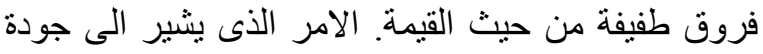

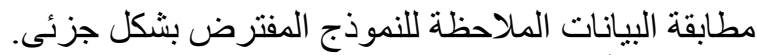

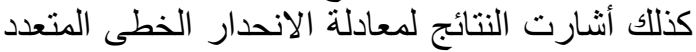

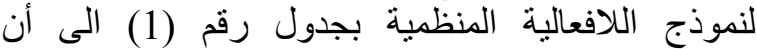

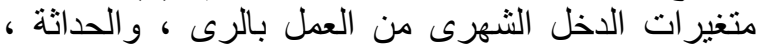

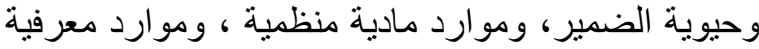

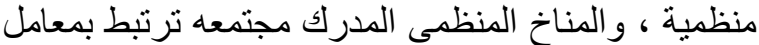

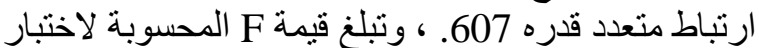

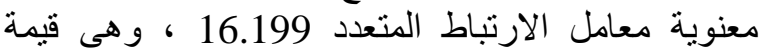

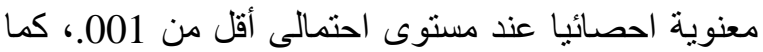

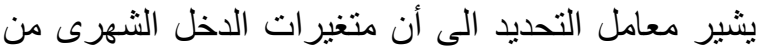

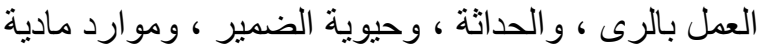

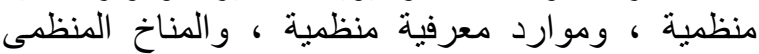
المدرك تنفر مجتمعه 60.7 \% من التباين فى متغير
من العمل بالرى، والحداثة، وحيوية الضمير، وموارد

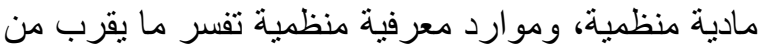

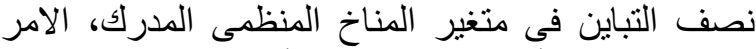

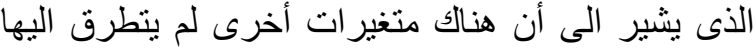

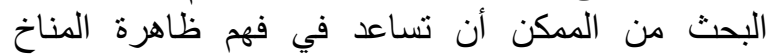

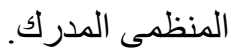

كما يتضح من النتائج أن كلا من متغير ات ات الحداثة،

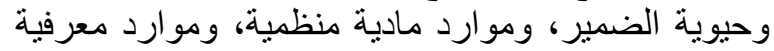

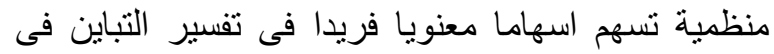

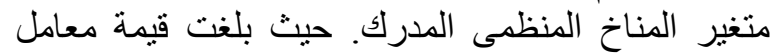

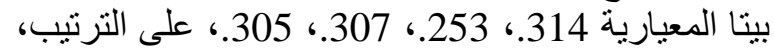

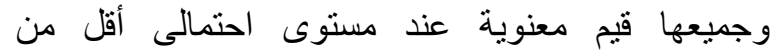

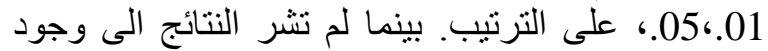

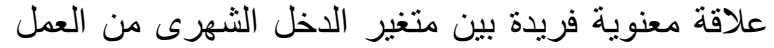

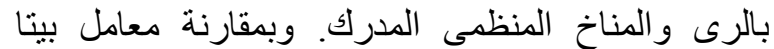

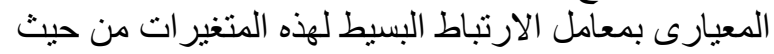

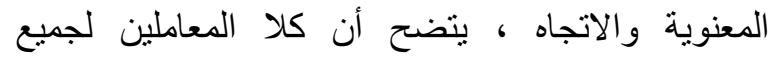

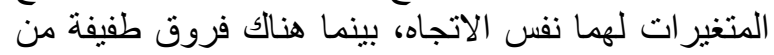

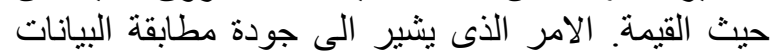
الملاحظة للنموذج المفتر المقرض.

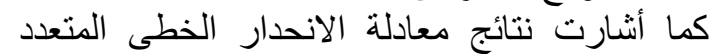

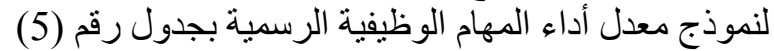

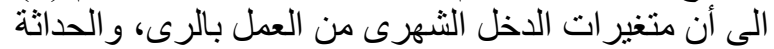

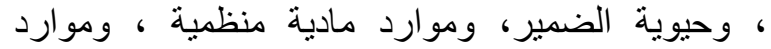

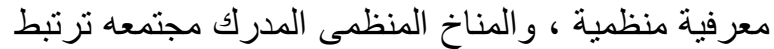

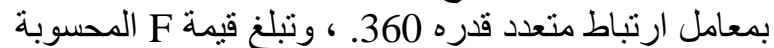

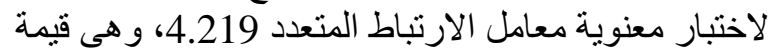

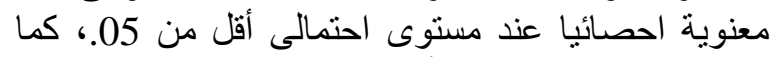

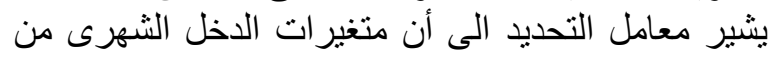

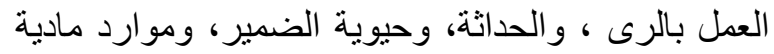

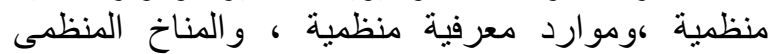
المدرك تفسر مجتمعه 36 \% من التباين فى متغير معدل 
منظمية كمتغير إدراكى - منظمى كانا الأكبر من حيث

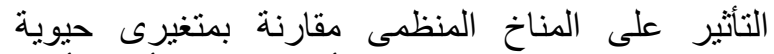
الضمير وموارد مادية منظمية. أما المتغير الأكثر تأثير التئير

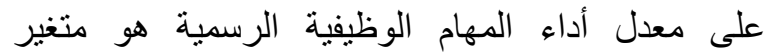

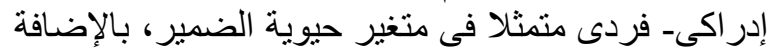

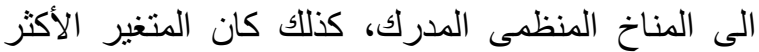

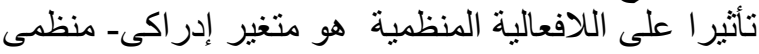

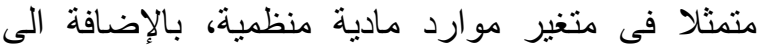
المناخ المنظمى المدرك.

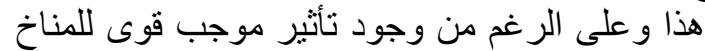
المنظمى المدرك على معدل أداء المهام الوظيفية الرسمية،

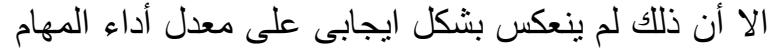
الوظيفية الرسمية؛ طبقا لنتائج النموذج النئي السببى النهائى. 3-4-4 الأثر السببى للمتغيرات الخارجية والألخانية للانموذج النهائى الأنى

للوقوف على الأثر السببى الكلى و الأثر المباثر و غير

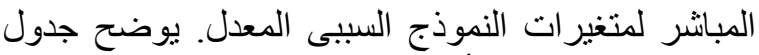

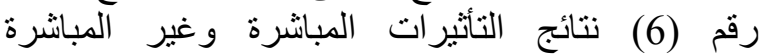

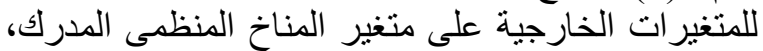

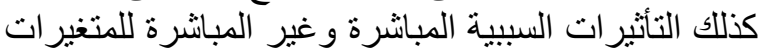

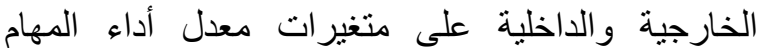

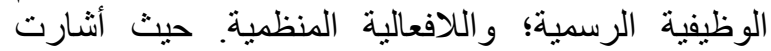
النتائج بجدول رقم (6) اللى أن المجموع الكئه الكلى للأثر

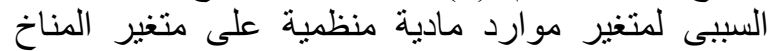

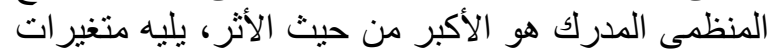

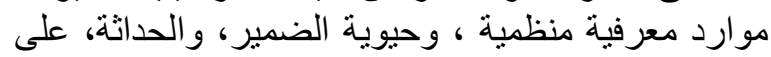

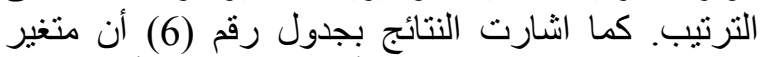

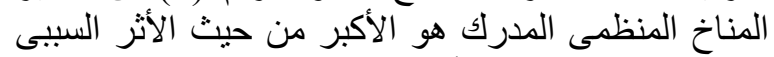

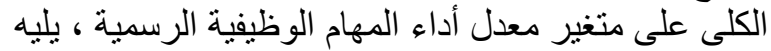

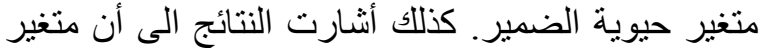

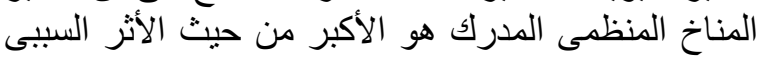

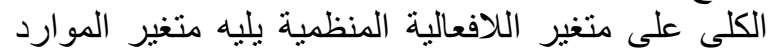
المادية المنظمية. هذه النتائج تشير الى أن متغير موارد مادية منظمية

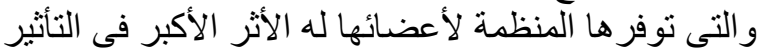

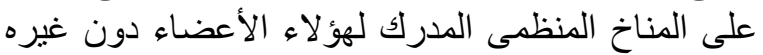

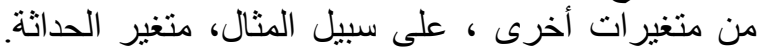
كذلك كان متغير المناخ المنظمى المدرك لـ اله الأثر الأكبر

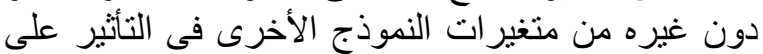
معدل أداء المهام الوظيفية الرسمية وكذلك التئ اللافعالية

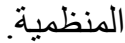
و عند المقارنة بين التأثير ات المباترة و التأثيرات غير الثير

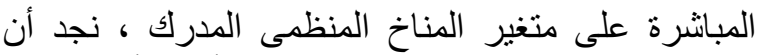

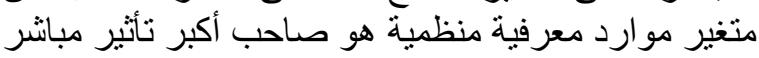

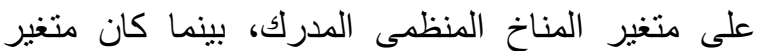
موارد مادية منظمية هو الأكبر من حيث المنير التأثير غير مئير

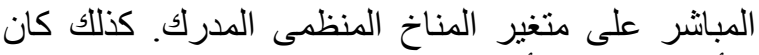
التأثير المباثر الأكبر لمتغير المناخ المنظمى المنير المدرك على كلى كانى

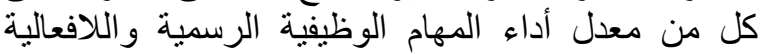

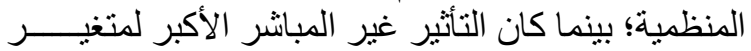

اللافعالية المنظمية، وهى نسبة كبيرة فى الدراسات

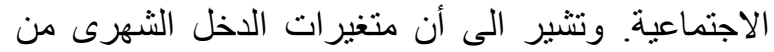

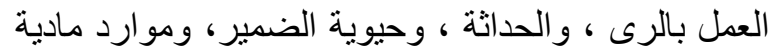

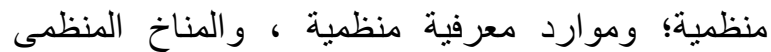

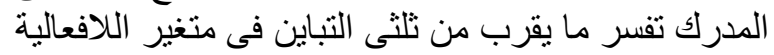

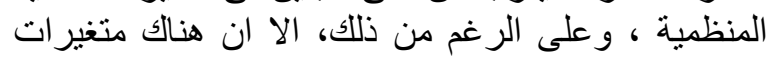

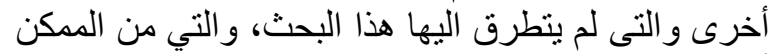

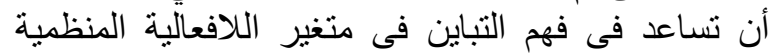

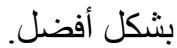
كما يتضح من النتائج أن كلا من متغيرى موارد

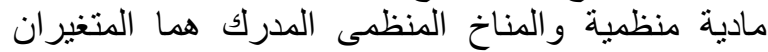

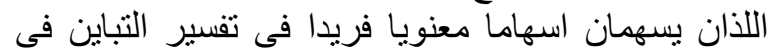

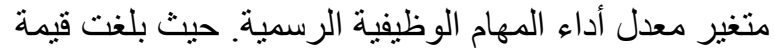

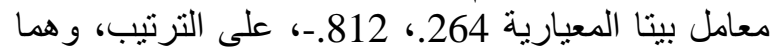

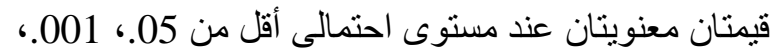

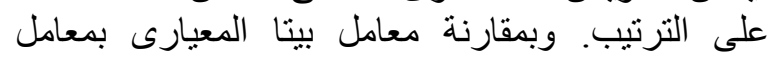

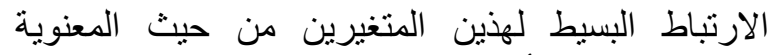

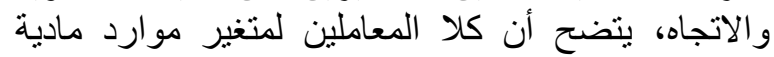

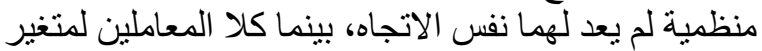

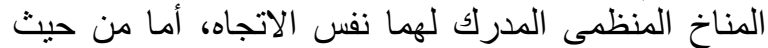

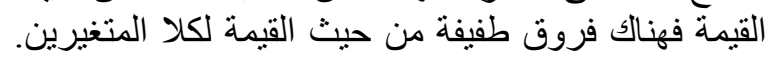
الامر الذى يشير الى جودة مطابقة البيانات الملاحظة

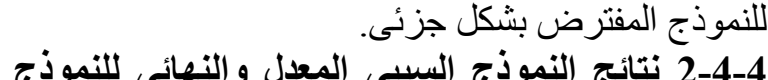

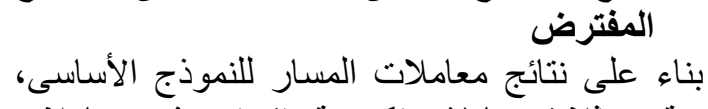

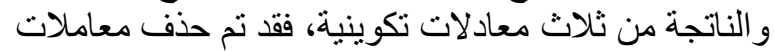

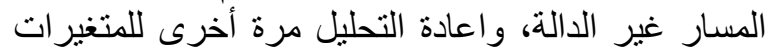

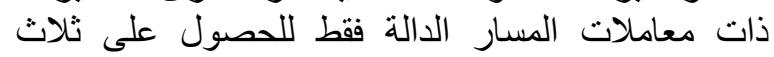
معادلات تكوينية جديدة، لتمثل المعادلات التكوينية الثثلاث

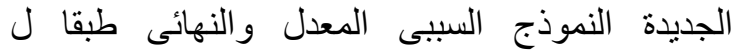
(Kerlinger and Pedhazur 1973)، ويعرض النجان الثكل رقم (2) نتائج النموذج السببى المعدل و النهائى.

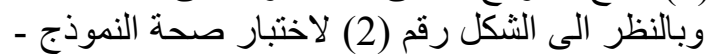

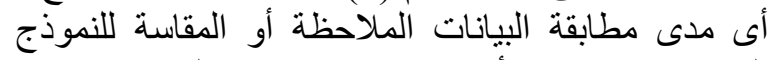

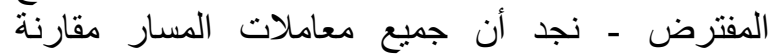

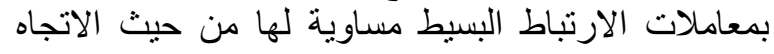

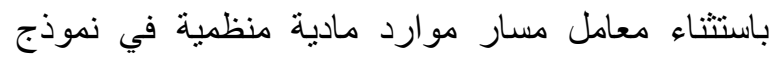
اللافعالية المنظمية ،حيث اتجاه معامل بادل بيتا المعيارى موجب الاتجاه، بينما معامل الارتباط البسيط سالب الاتجاه التاه

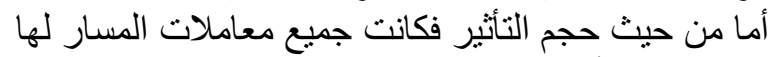

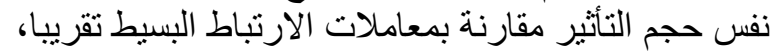

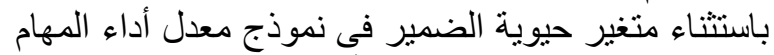

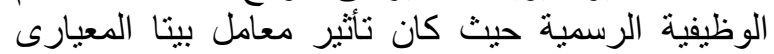

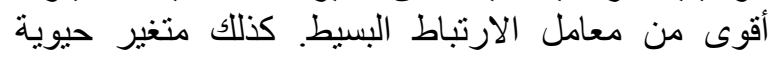

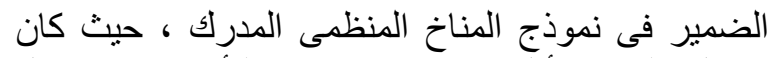

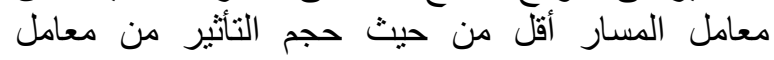
الارنباط البسيط. يتضح من نتائج النموذج السببى النهائى أن متغيرى

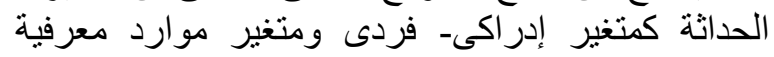




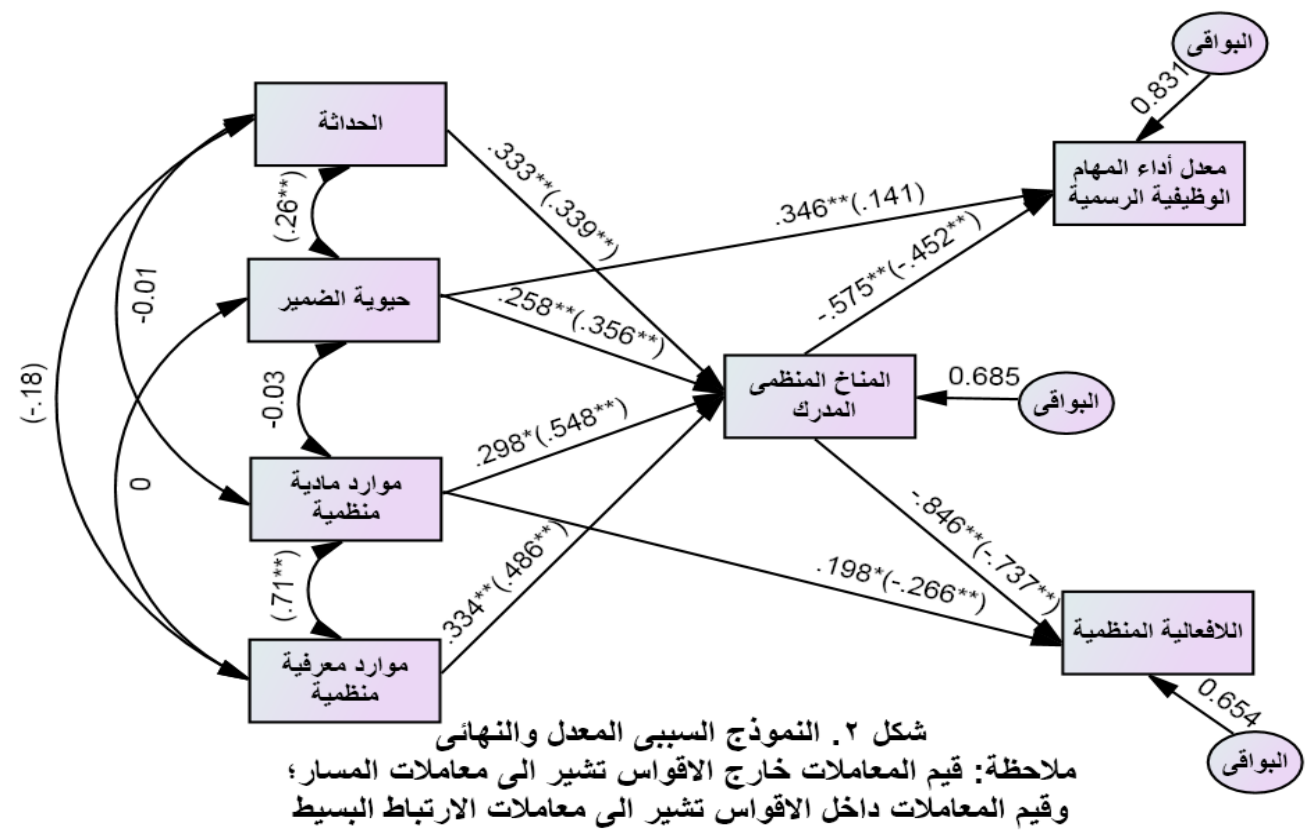

\begin{tabular}{|c|c|c|c|c|c|c|}
\hline \multicolumn{7}{|c|}{ ي والأثر المباشر وغير المباشر للنموذج السببى المعدل والنهائى. } \\
\hline الارتباط & الارتباط & الأثر السببى الكلى & غير الأثباشبر السببى & الأثر السببى & 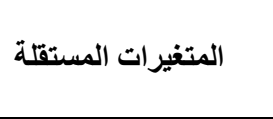 & النموذج \\
\hline .339 & .005 & .334 & .004 & .330 & 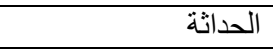 & \multirow{4}{*}{ المناخ المنظمى المدرك } \\
\hline .356 & .021 & .335 & .077 & .258 & حيوية الضمير & \\
\hline .548 & .024 & .524 & .226 & .298 & موارد مادية منظمية & \\
\hline .486 & .001 & .485 & .151 & .334 & موارد معرفية منظمية & \\
\hline .141 & -.057 & .198 & -.148 & .346 & حيوية الضمير & \multirow{2}{*}{ الوظدلية أداء المهمية } \\
\hline-.452 & .034 & -.486 & .089 & -.575 & المناخ المنظمى المدرك & \\
\hline-.266 & -.293 & .027 & -.171 & .198 & مو ارد مادية منظمية & \multirow[t]{2}{*}{ اللافعالية المنظمية } \\
\hline-.737 & .050 & -.787 & .059 & -.846 & المناخ المنظمى المدرك & \\
\hline
\end{tabular}

الرسمية؛ ومعادلة نموذج اللافعالية المنظمية. و هذه النتائج

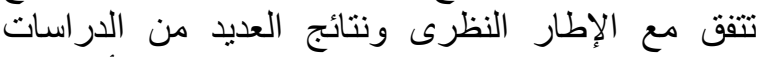

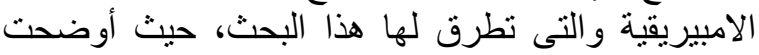

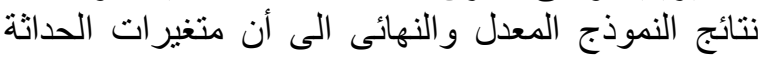

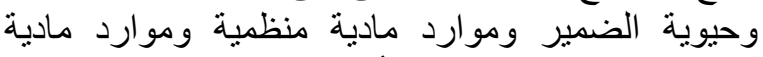

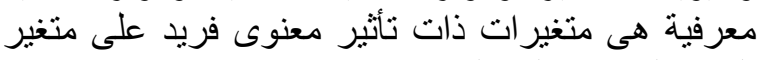

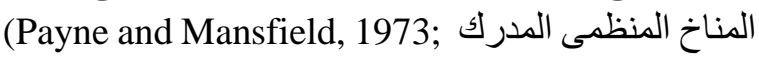
. (Rao, 2014 كما أوضحت النتائج أن كلا من متغيرى حيوية

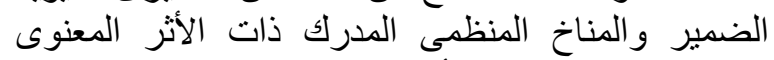

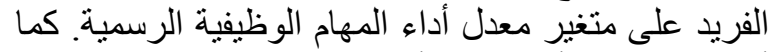

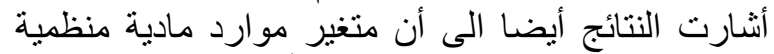

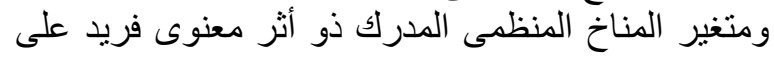
متغير اللافعالية المنظمية.

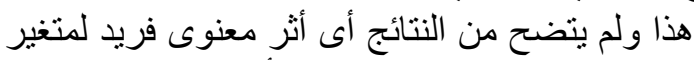

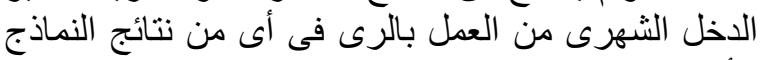

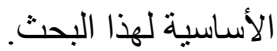

حيوية الضمير على متغير معدل أداء المهام الوظيفية

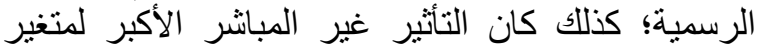
موارد مادية منظمية على متغير اللافعالية المنظمية.

$$
\text { 5- الاستنتاجات والمقترحات }
$$

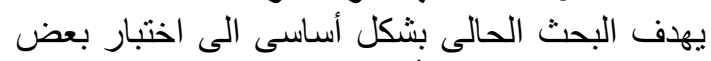

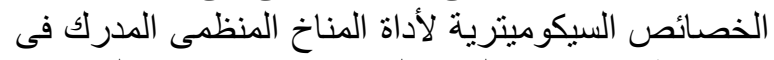

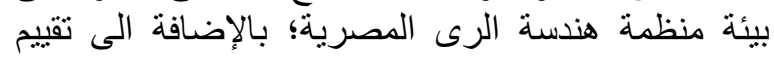

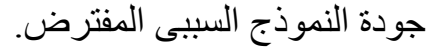
حيث أثنارت أهم نتائج هذا البحثث الى وجئ وجود تمايز

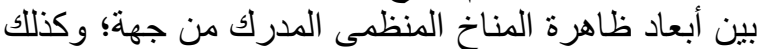

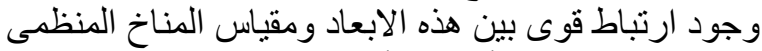

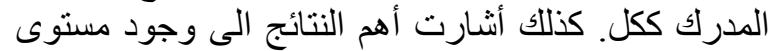

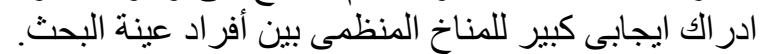

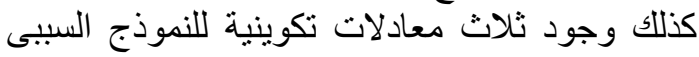

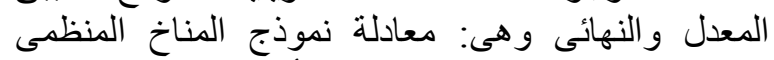
المدرك؛ ومعادلة نموذج معدل معلئ أداء المهام الوذاخ الوظيفية 


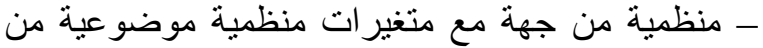

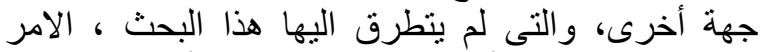

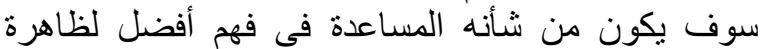

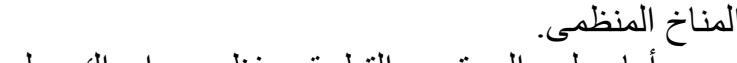

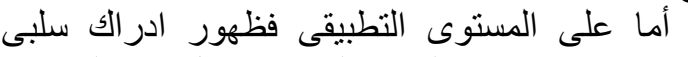

كبير تجاه بعض ابعاد المناخ المنظمى مثل بعد التخطيط

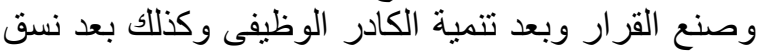

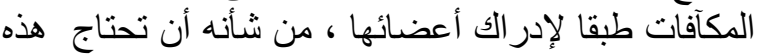
الابعاد الى اهتمام وتدخل سريع من خلال خطة الادر عمل الهل

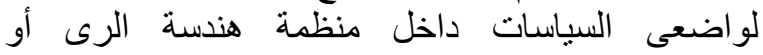

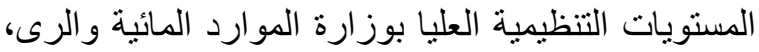

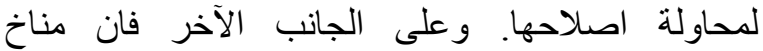
الاتصالات ومناخ الاحتر ام والذى بسود الألى المنظمة طبقا

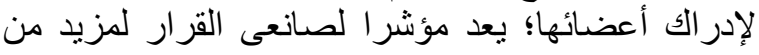

السياسات و الجهود للمحافظة عليه وتتميته.
كما أشارت أهم النتائج الى أن متغير موارد مادية

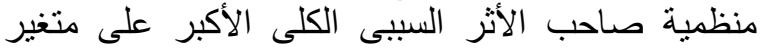

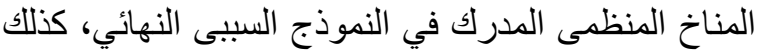

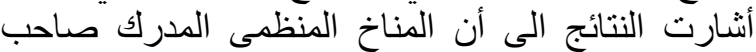

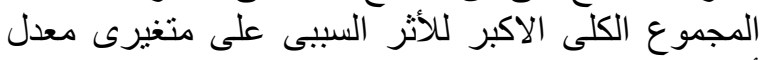
أداء المهام الوظيفة الرسمية و اللافعالية المنظمية.

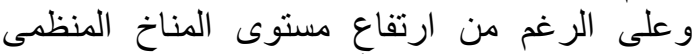

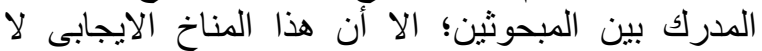
يعكس معدل أداء المهام الوظيفية الرسمية لهؤلاء العاملين الإنين

(Berberoglu, 2018; Mullins and Christy, 2010). وبناء على ذللك، يقترح هذا البحث مزيد من البحوث

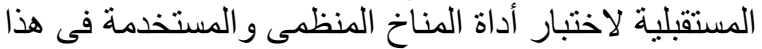
البحث لاختبار ثبات وصدق هذه الأداة فى بيئات منظمية

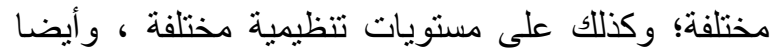

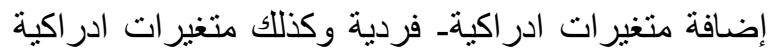

الملاحق المقاد)

ملحق(1) أداة المناخ المنظمى المستخدمة فى هذا البحث (النسخة العربية).

م موافيز

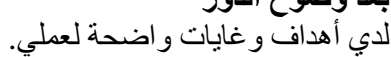
أناو اضتح بشأن أولويات أني في العمل. أنا أعرف ما هي مسؤولنياتي.

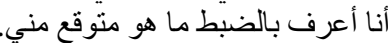

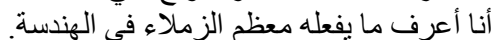

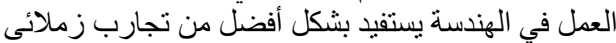

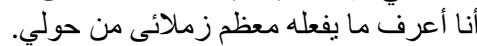

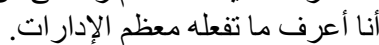
الهندسة لديها موظفين ذات نوفئ الإدية جيدة. بعد الاحترام أشعر بالتقدير من قبل زملائي في الهندسة. أقدر زملائي في الهندسة. أشعر بالتقدير من قبل زملانلائي في الهندسة.

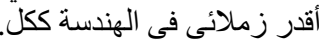

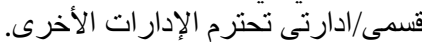

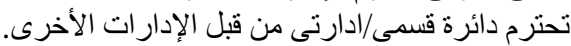
بعد الاتصالات أتلقى جميع المعلومات التهي ألتات أحتاجها للقيام بعملي.

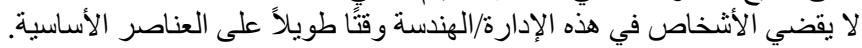

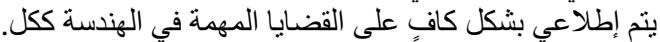

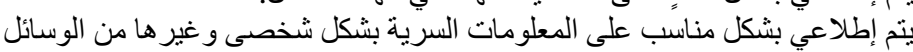
غير الرسمية. 20 21 2 20

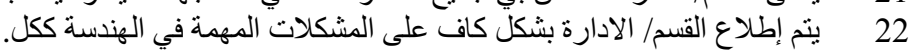
23 24 25 2 26 26 25 أنا أعمل بفعالية لأن الموظفين الآخرين يتو الصلونة فئون معي بانتظام. بعد نست المكافآت 28

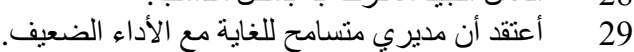
30 31 3 30 


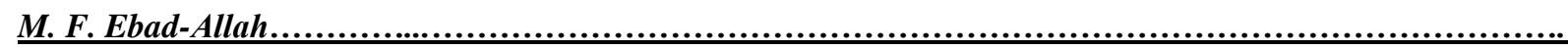

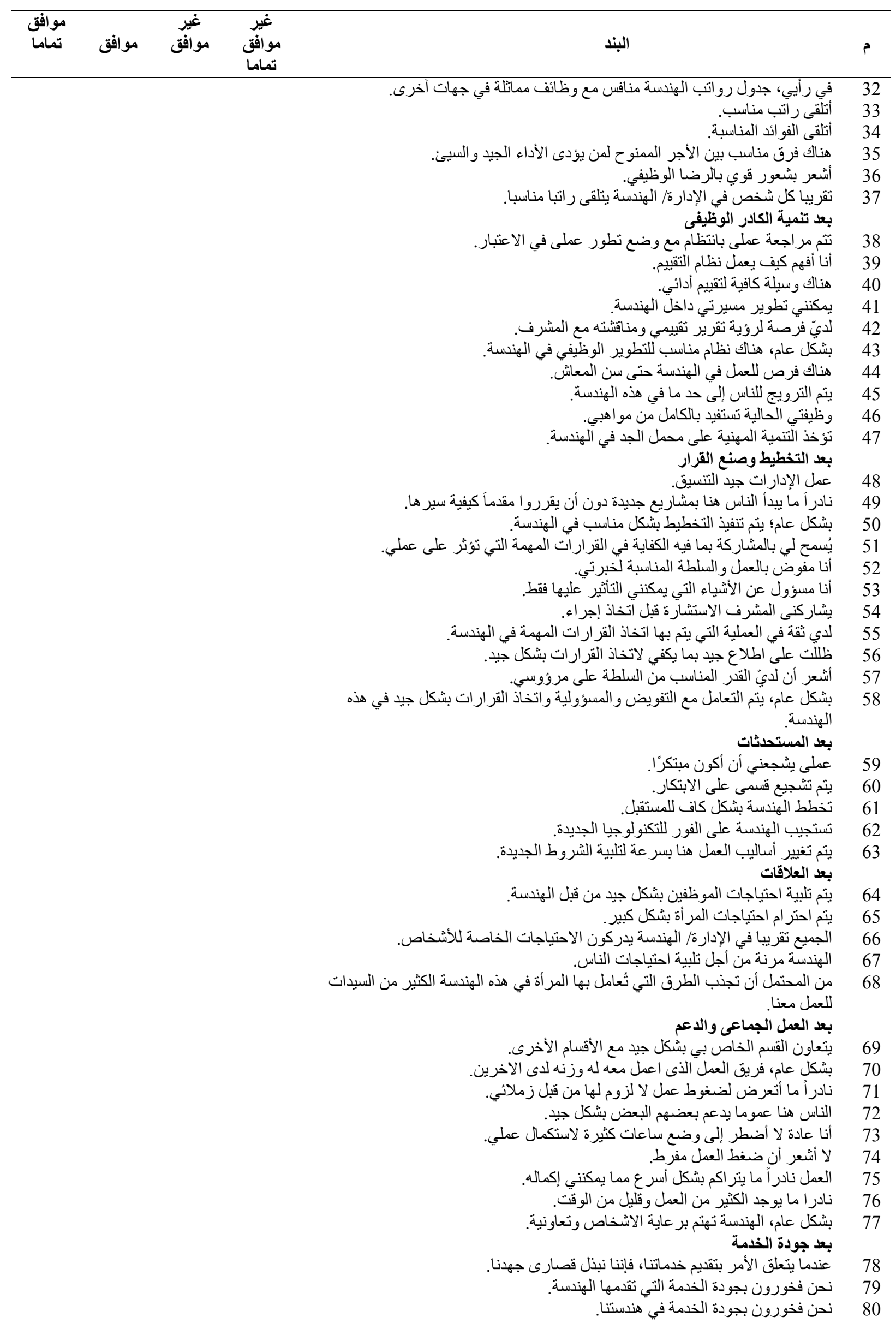




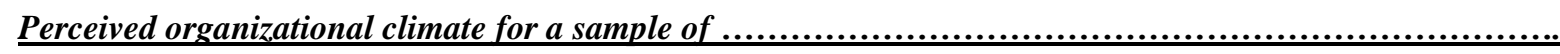

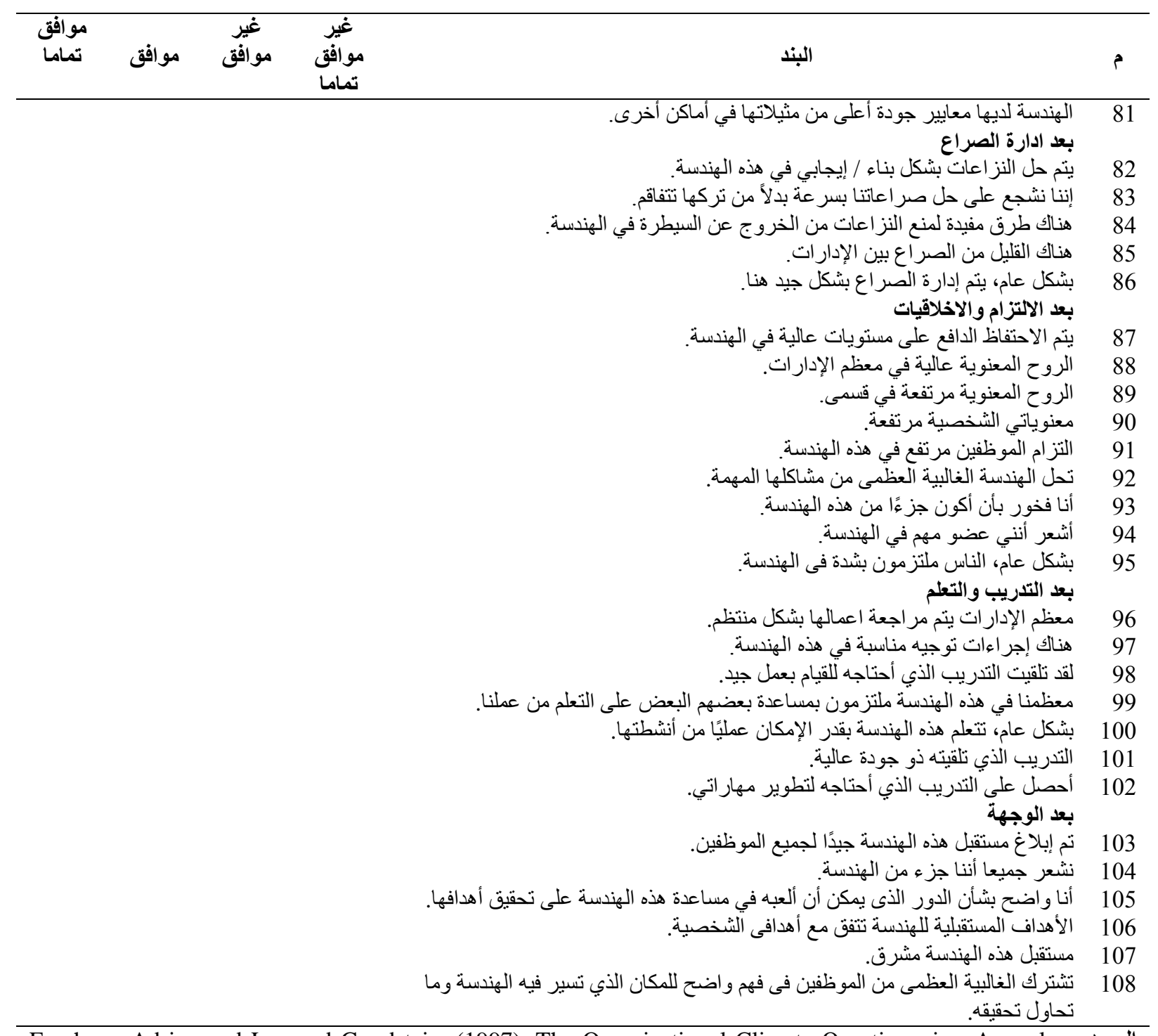

المصدر: . Farnham, Adrian and Leonard Goodstein. (1997). The Organizational Climate Questionnaire. Annual. Volume 2, Consulting, Pfeiffer. ملاحظة: تم التعريب من قبل المؤلف، و اجر اء بعض التعديلات الطفيفة لكى تتو افق مع أهداف هذا البحث.

\begin{tabular}{|c|c|c|c|c|c|c|c|c|c|}
\hline 8 & 7 & 6 & 5 & 4 & 3 & 2 & 1 & المتغيرات الخارجية والداخلية بالنموذج السببي الاساسىى & \\
\hline & & & & & & & 1.00 & الاخل الشهزى من العمل بالرى & $\mathbf{1}$ \\
\hline & & & & & & 1.00 & -.08 & الحداثة & 2 \\
\hline & & & & & 1.00 & $.26^{* *}$ & -.05 & الضمير & 3 \\
\hline & & & & 1.00 & .04 & .01 & -.08 & موارد مادية منظمية & 4 \\
\hline & & & 1.00 & $.71^{* *}$ & .01 & -.18 & -.13 & موارد معرفية منظمية & 5 \\
\hline & & 1.00 & $.49^{* *}$ & $.55^{* *}$ & $.36^{* *}$ & $.34^{* *}$ & $-.26-^{*}$ & المنـاخ المنظمى المدرك & 6 \\
\hline & 1.00 & $-.45-^{* *}$ & $-.43-^{* *}$ & $-.48-^{* *}$ & .14 & -.06 & .15 & معدل أداء المهام الوظيفية الرسمية & 7 \\
\hline 1.00 & $.26^{*}$ & $-.74-^{* *}$ & $-.30-^{* *}$ & $-.27-^{* *}$ & $-.22-^{*}$ & $-.40-^{* *}$ & .15 & اللافعالية المنظمية & 8 \\
\hline
\end{tabular}




\begin{tabular}{|c|c|c|c|c|c|c|c|}
\hline \multicolumn{2}{|c|}{ نموذج الللافعالية } & \multicolumn{2}{|c|}{ نموذج معدل أداء المهام } & \multicolumn{2}{|c|}{ نموذج المناخ المنظمى المدرك } & \multirow[t]{2}{*}{ المتغير المستقل } & \\
\hline$(\beta)$ & $(\mathrm{r})$ & $(\beta)$ & $(\mathrm{r})$ & $(\beta)$ & (r) & & \\
\hline- & - & - & - & $.330 * * *$ & .339 & الحداثة & 1 \\
\hline- & - & $.346^{* *}$ & .141 & $.258 * *$ & .356 & حيوية الضمير & 2 \\
\hline $.198 *$ & -.266 & - & - & $.298^{*}$ & .548 & مو ارد مادية منظمية & 3 \\
\hline- & - & - & - & $.334 * *$ & .486 & موارد معرفية منظمية & 4 \\
\hline$-.846 * * *$ & -.737 & $-.575 * * *$ & -.452 & - & - & المناخ المنظمى المدرك & 5 \\
\hline 47.979*** & - & $10.937 * * *$ & - & $19.709 * * *$ & - & $\mathrm{F}$ & \\
\hline .571 & - & .309 & - & .530 & - & معامل التحديد R & \\
\hline .654 & - & .831 & - & .685 & - & معامل مسار البو اقى & \\
\hline
\end{tabular}

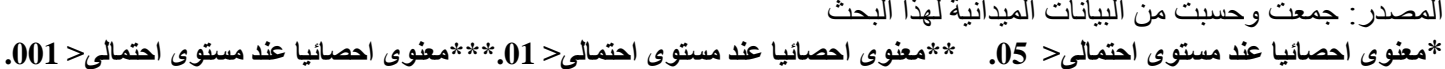

\section{REFERENCES}

Arora N., Nuseir M. T., Nusair T. T. and Arora R.(2012). Study-based moderators influencing the relationship between organizational climate and employee's organization commitment:A meta-analysis Euro Med J. Bus. ,7(2): 201-220. https://doi.org/10.1108/14502191211245615.

Barth R.(1974). Organizational commitment and identification of engineers as a function of organizational climate. Relations Industrielles/Industrial Relations,29(1): 185-199.

Bartram D., Robertson I., and Callinan M. (2008). Introduction: A framework for examining organizational effectiveness. In I. T. Robertson, M. Callinan, \& D. Bartram (Eds.), Organizational effectiveness: The role of psychology (pp. 1-10). Chichester, UK: Wiley.

Berberoglu A. (2018). Impact of organizational climate on organizational commitment and perceived organizational performance: Empirical evidence from public hospitals. $B M C$ Health Services Research: 18(1), 399.

Brown S. P. and Leigh T. W. (1996). A new look at psychological climate and its relationship to job involvement, effort, and performance. J. Appl. Psychol., 81(4): 358-368.

Burke M. J., Borucki C. C., and Hurley A. (1992). Reconceptualizing psychological climate in a retail service environment:

A multiple-stakeholder perspective. J. Appl. Psychol., 77(5): 717-729.

Campbell J. P., Dunnette M. D., Lawler E. E.,
Weick K. E. (1970). Managerial behavior, performance and effectiveness. New York: McGraw-Hill Book Company.

Chai L. and Singh S. K. G. (2008). A relationship between organizational climate, employee personality and intention to leave. Int. '1 Rev. Bus. Res. Papers, (4): 1-10.

Chatman J. (1989). Improving interactional organizational research: A model of person-organization fit. Acad. Manag. Rev.,(14):333-349. https://doi.org/10.2307/258171

Coda R., da Silva D. and Custodio I. (2015). Multidimensional configurations of the organizational climate construct. The Int. '1 J. Human Res. Manag.,26(14):1827-1847. https://doi.org/10.1080/09585192.2014.962561.

Cohen J. (2013). Statistical power analysis for the behavioral sciences. New York: Routledge. https://doi.org/10.4324/9780203771587.

Danish R., Draz U., Ali H. and Ali. (2015). Impact of organizational climate on job satisfaction and organizational commitment in education sector of Pakistan. Amer. J. Mobile Sys., Appli. Serv., 1: 102-109.

D'Cunha P. (1999). A study on organisational climate in the hospital set-up. Rajagiri College of Social Sciences, India: Kalamassery.

DeCotiis T. A. and Summers T.P. (2016). A path analysis of a model of the antecedents and consequences of organizational commitment. Human Relations, 40(7): 445-470.

https://doi.org/10.1177/001872678704000704 
Dickson M. W., Resick C. J. and Hanges P. J. (2006). When organizational climate is unambiguous, it is also strong. J. Appli. Psychol.,91(2):351-364. https://doi.org/10.1037/0021-9010.91.2.351.

Farnham A. and Goodstein L. (1997). The organizational climate questionnaire. Annual: Vol. 2, Consulting, Pfeiffer.

Gani A. and Shah F. A. (2001). Correlates of organisational climate in banking indus. Indian J. Indus. Relations, 36(3):301-322. https://www.jstor.org/stable/27767726.

Garson D. (2013). Validity and reliability. Statistical Associates Blue Book Series 12, USA: Statistical Associates Publishers.

Glick W. H. (1985). Conceptualizing and measuring organizational and psychological climate: Pitfalls in Multilevel Research. The Acad. Manag. Rev.,10(3):601-616. https://doi.org/10.2307/258140.

Goldberg, L. R. (1999). A broad-bandwidth, public domain, personality inventory measuring the lower-level facets of several five-factor models. In I. Mervielde, I. Deary, F. De Fruyt, \& F. Ostendorf (Eds.), Personality Psychology in Europe, Vol. 7 (pp. 7-28). Tilburg, The Netherlands: Tilburg University Press.

Habibullah A. H. M. and Sinha J. B. P. (2016). Motivational climate and leadership styles. Vikalpa, 5(2): 85-94. https://doi.org/10.1177/0256090919800.

Hall D. T. and Schneider B. (1973). Organizational climates and careers: The work lives of priests. New Jercy: Seminar Press.

House R. J. and Rizzo J. R. (1972). Toward the measurement of organizational practices: Scale development and validation. J. Appl.Psychol.,56(5):388-396. https://doi.org/10.1037/h0033444.

Idogho P. O. (2006). Academic staff perception of the organizational climate in Universities in Edo State, Nigeria. J. Soc. Sci.,13(1):71-78. https://doi.org/10.1080/09718923.2006.11892533

James L. A. and James L. R. (1989). Integrating work environment perceptions: Explorations into the measurement of meaning. J.Appl. Psychol.,74(5):739-751. https://doi.org/10.1037/0021-9010.74.5.739

James L. R. (1982). Aggregation bias in estimates of perceptual agreement. J.
Appl.Psychol.,67(2):219-229.

https://doi.org/10.1037/0021-9010.67.2.219

James L. R. and Jones A. P. (1974). Organizational climate: A review of theory and research. Psychological Bulletin,81(12):1096-1112. https://doi.org/10.1037/h0037511

Joyce W. F. and Slocum J. W. (1984). Collective climate: Agreement as a basis for defining aggregate climates in organizations. Acad. Manag.J.,27(4):721-742. https://doi.org/10.2307/255875

Jyoti J. (2013). Impact of organizational climate on job satisfaction, job commitment and intention to leave: An empirical model. J.

Bus.Theory and Pract., (1): 66. https://doi.org/10.22158/jbtp.v1n1p66

Kangis P. Gordon D. and Williams S. (2000). Organisational climate and corporate performance: An empirical investigation. Manag.Decis.,(38):531-540. https://doi.org/10.1108/EUM0000000005371.

Kerlinger F. N., \& Pedhazur, E. J. (1973). Multiple regression in behavioral research. New York: Rinehart and Winston Company.

Khan N. (2019). The impact of organizational climate on teachers commitment. J. Educ. Educat.Develop.,6(2):327-342. https://eric.ed.gov/?id=EJ1235085.

Koffka K. (1935). Principles of gestalt psychology. California: Harcourt Publisher.

Koys D. J. and DeCotiis T. A. (1991). Inductive measures of psychological climate. Human Relations, 44(3):265-285. https://doi.org/10.1177/001872679104400304.

Kristof-Brown A. L., Zimmerman R. D. and Johnson E. C. (2005). Consequences of individual's fit at work: A meta-analysis of person-job, person-organization, person-group, and person-supervisor fit. Perso. Psychol., 58(2): 281-342. https://doi.org/10.1111/j.1744-6570.2005.00672.x

Lawler E. E., Hall D. T. and Oldham G. R. (1974). Organizational climate: Relationship to organizational structure, process and performance. Organiz. Beha. Human Perform., 11(1): 139-155. https://doi.org/10.1016/0030-5073(74)90010-5 Lewin K., Lippitt R. and White R. K. (1939). Patterns of aggressive behavior in experimentally created "Social climates." J. Soc. Psychol., 10 : 271-299. https://doi.org/10.1080/00224545.1939.9713366. 
Lewin K. (1951). Field theory in social science: Selected theoretical papers (Edited by Dorwin Cartwright.). New York: Harper $\&$ Brothers.

Likert R. (1961). New patterns of management. New York: McGraw-Hill Book Company Inc.

Lindell M. K. and Brandt C. J. (2000). Climate quality and climate consensus as mediators of the relationship between organizational antecedents and outcomes. J.Appl. Psychol., 85(3):331-348.

https://doi.org/10.1037/0021-9010.85.3.331

Litwin G. H. and Stringer R. A. (1968). Motivation and organizational climate. Division of Research, Graduate School of Business Administration, Harvard University, USA.

Moos R. H. (1974). Evaluating treatment environments: A social ecological approach. New Jersey: Wiley-Interscience series.

Moran E. T. and Volkwein J. F. (1992). The cultural approach to the formation of organizational climate. Human Relations, 45(1):19-47. https://doi.org/10.1177/001872679204500102.

Mullins L. and Christy G. (2010). Management and organisational behaviour. Finan. Times Prentice Hall. Harlow, Essex.

Nammi A. Z. and Nezhad M. Z. (2009). The relationship between psychological climate and organizational commitment. https://doi.org/10.3923/JAS.2009.161.166

Ory J. and Wise S. (1981). Attitude change measured by scales with 4 and 5 response options. Paper Presented at the Meeting of the National Council on Measurement in Education, Chicago, IL,USA.

Ostroff C. (1993). The effects of climate and personal influences on individual behavior and attitudes in organizations. Organization. Behavior and Human Decision Processes, 56(1):56-90. https://doi.org/10.1006/obhd.1993.1045.

Pace C. R. and Stern G. G. (1958). An approach to the measurement of psychological characteristics of college environments. J. Edu. Psychol., 49(5) : 269-277. https://doi.org/10.1037/h0047828.

Patterson M. G., West M. A., Shackleton V. J., Dawson J. F., Lawthom R., Maitlis S., Robinson D. L. and Wallace A. M. (2005). Validating the organizational climate measure: Links to managerial practices, productivity and innovation. $\mathrm{J}$. Organization. Behavior, 26(4): 379-408. https://doi.org/10.1002/job.312

Patterson M., Warr P. and West M. (2004). Organizational climate and company productivity: The role of employee affect and employee level. J. Occup. Organ. Psychol.,77(2):193-216. https://doi.org/10.1348/096317904774202144

Payne R. L. and Pheysey D. C. (1971). G. G. Stern's organizational climate index: A reconceptualization and application to business organizations. Organization. Beh. and Human Perform., 6(1): 77-98. https://doi.org/10.1016/0030-5073(71)90006-7

Payne Roy L. and Mansfield R. (1973). Relationships of perceptions of organizational climate to organization. structure, context, and hierarchical position.Admin.Sci.Quar.,18(4):515-526. https://doi.org/10.2307/2392203.

Peña-Suárez E., Muñiz J., Campillo-Álvarez A., Fonseca-Pedrero E. and García-Cueto E. (2013). Assessing organizational climate: Psychometric properties of the CLIOR Scale. Psicothema, 25(1): 137-144. https://doi.org/10.7334/psicothema2012.260.

Pritchard R. D. and Karasick B. W. (1973). The effects of organizational climate on managerial job performance and job satisfaction. Organiz. Behavior \& Human Perform., 9(1): 126-146. https://doi.org/10.1016/0030-5073(73)90042-1

Rao G. V. (2014). A study on predictor variables of organizational climate in educational institutes. Acta Univ. Danubius. Economica,10(6):33-47. https://www.ceeol.com/search/articledetail?id=572262.

Raza S. (2010). Impact of organizational climate on performance of college teachers in Punjab. J. College Teaching and Learning earning (TLC), 7 (10): 47-52. https://doi.org/10.19030/tlc.v7i10.155

Reddy T. C., Gajendran M. and Gayathri S. (2000). Organisational climate and dual commitment in private and public sector enterprises. Indian J. Indus. Relat.,36(1):53-66. https://www.jstor.org/stable/27767697

Reichers A. E. and Schneider B. (1990). Climate and culture: An evolution of constructs. In B. Schneider, (ed.) Organizational climate and culture. San Francisco, California: Jossey-Bass Inc., Publishers. (pp. 5-39). 
Rousseau D. M. and Tijoriwala S. A. (1998). Assessing psychological contracts: Issues, alternatives and measures. J.Organization. Behav.,19(Spec Issue): 679-695.

Schnake M. E. (1983). An empirical assessment of the effects of affective response in the measurement of organizational climate. Perso.Psychol., 36(4): 791-807.

Schneider B. and Reichers A. E. (1983). On the etiology of climates. Personnel Psychology,36(1):19-39.

Schneider Benjamin and Snyder R. A. (1975). Some relationships between job satisfaction and organization climate. J. Appl. Psychol., 60(3): 318-328.

Schyns B., Veldhoven M. J. P. M. van and Wood S. (2009). Organisational climate, relative psychological climate and job satisfaction: The example of supportive leadership climate. Leadership and Organiz. Develop. J., 30(7):649-663.

Shadur M. A., Kienzle R. and Rodwell J.J. (1999). The relationship between organizational climate and employee perceptions of involvement:

The importance of support. Group and Organization Management,24(4):479-503. https://doi.org/10.1177/1059601199244005

Shafer W. E. (2009). Ethical climate, organizational-professional conflict and organizational commitment: A study of Chinese auditors. Account., Audi. Account. J., 22(7):1087-1110.

Sharma D. B. (2016). A focus on reliability in developmental research through Cronbach's Alpha among medical, dental and paramedical professionals. Asian Pacific J. Health Sci., 3(4):271-278.

Stern G. G. (1970). People in context measuring person-environment congruence in education and industry. New York: Wiley.
Stringer R. A. (2002). Leadership and organizational climate: The Cloud Chamber Effect. Upper Saddle River. New Jersey: Prentice Hall.

Tabachnick B. G. and Fidell L. S. (2007). Using multivariate statistics, 5th ed (pp. xxvii, 980). Boston, Massachusetts: Allyn and Bacon/Pearson Education.

Tagiuri R., Litwin G. H., Barnes L. B. (1968). Organizational climate: Explorations of a concept. Boston: Division of Research, Graduate School of Business Administration, Harvard University.

Taylor J. C. and Bowers, D. G. (1972). Survey of organizations: A machine-scored standardized questionnaire instrument. Ann Arbor: Center for Research on Utilization of Scientific Knowledge, University of Michigan.

Tripathi S. and Tripathi N. (2002). The effect of organizational climate on organizational success. Indian J.Indus.Rela.,(38):161176.

van den Hooff B. and de Ridder J. A. (2004). Knowledge sharing in context: The influence of organizational commitment, communication climate and CMC use on knowledge sharing. J. Knowl. Manag., 8(6):117-130.

Vashdi D. R., Vigoda-Gadot E. and Shlomi D. (2013). Assessing performance: The impact of organizational climates and politics on public schools' performance. Pub. Admin., 91(1): 135-158.

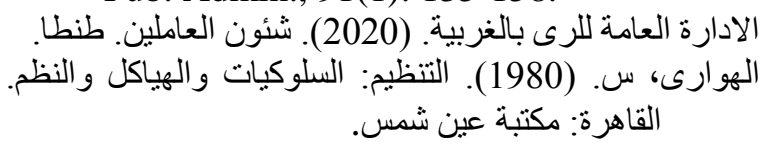

